\title{
Botanical Prospecting
}

\section{For Uranium on}

South Elk Ridge

\section{San Juan County, Utah}

By FRANK J. KLEINHAMPL

BOTANICAL PROSPECTING FOR URANIUM ON THE COLORADO PLATEAU

G E O L O G I C A L S U R V E Y B U L L E T I N $1085-\mathrm{D}$

Prepared on behalf of the U.S. Atomic Energy Commission and published with the permission of the Commission

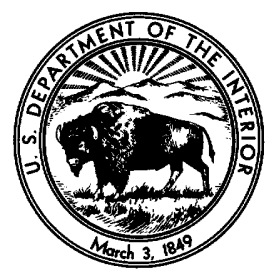


UNITED STATES DEPARTMENT OF THE INTERIOR

STEWART L. UDALL, Secretary

\author{
GEOLOGIGAL SURVEY
}

Thomas B. Nolan, Director 


\section{CONTENTS}

Page

Abstract

Introduction $\ldots \ldots \ldots$

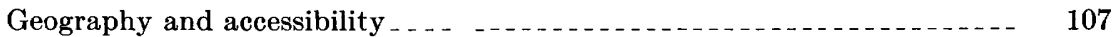

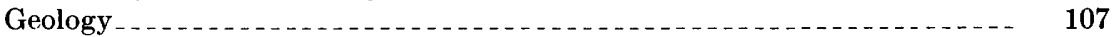

Ore deposits . .

Guides to ore

Plant ecology . . .

Botanical prospecting . .

Indicator plants $\ldots$

Plant-analysis prospecting 118

Botanical anomalies................................... 118

Sample type, interval, and horizon ................... 120

Uranium content of trees and botanical anomalies . . . . . . . . 124

Botanical anomalies at South Elk Ridge - a prospector's guide _. . . . . . 131

Subarea 1-S (south of The Notch) _._.

1-N (north of The Notch) .

2 (Kigalia Canyon) . . . . . . . . . . 141

3 (Peavine Canyon) $\ldots \ldots \ldots \ldots$

4 (Cherry Canyon)

5 (Woodenshoe Canyon)

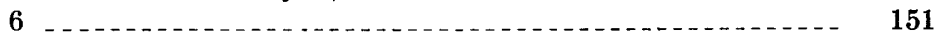

7 (Burch Canyon) $\ldots \ldots \ldots$

8 (Lyman Canyon)

9 (Arch Canyon)

Evaluation of plant-analysis prospecting

Success evaluation based on drilling

Choice of drill-test localities and drilling procedure_......... 158

Interpretation of drilling results $\ldots \ldots$

Interpretation based on gamma-ray $\log$ data $\ldots \ldots \ldots \ldots$

Interpretation based on actual uranium content of drill core and

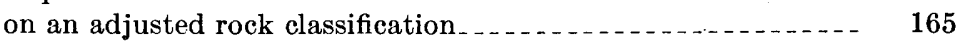

Success evaluation based on radioactivity testing

Reliability of plant-sample analysis and sampling methods...... 170

$\begin{array}{ll}\text { Relation of uranium in trees to other elements in rock and regolith_ } & 171\end{array}$

General summary and conclusions.

Literature cited .................. 185

Standard plant names used in this report 


\section{ILLUSTRATIONS}

Plate 9. Botanical anomaly map, Elk Ridge area............. In pocket

FIgURe 5. Index map of part of Elk Ridge and vicinity

6. View looking west across Dark Canyon from The Notch

7. Sketched longitudinal profile at botanical anomaly 5 , subarea $4 \ldots \ldots \ldots$

8. Sketched longitudinal profiles at botanical anomalies._._._. 123

9. Frequency distribution of plant samples........ 124

10. Frequency distribution of sampled oaks _...

11. Sketch map showing distribution of onion plants _...... 137

12. Relations between botanical anomalies and ground favorable for containing ore deposits_.....

13. Results of control sampling ...

14. Results of close-spaced drilling, based on gamma-ray log data . 161

15. Plant sample and gamma-ray log drill hole data at botanical anomaly $17 \ldots \ldots 2$

16. Plant sample and gamma-ray log drill hole data at botanical anomaly 2.

17. Comparison of curves showing uranium content of trees at botanical anomaly 2

162

163

164

18. Results of close-spaced drilling, based on adjusted data.....-

19. Plant sample results compared to adjusted drilling data at botanical anomaly 17 .

20. Plant sample results compared to adjusted drilling data at botanical anomaly $2 \ldots \ldots \ldots$ 


\section{TABLES}

TABLE 1. Analyses of grab samples of mineralized rock from the Shina-

rump member of the Chinle formation at different localities on Elk Ridge, San Juan County, Utah

Page

2. $F$ and $t$ values calculated for pairs of tree populations....

3. Significant uranium and average ash content in plants and results of frequency distribution studies of different plant populations

4. Examples illustrating how the evaluation of botanical anomalies is altered by the consideration of adjusted cutoffs denoting an anomalous amount of uranium and the degree of contrast between uranium contents of trees

5. Uranium in basal rocks of the Chinle formation at botanical anomalies and at widely spaced drill sites...............

6. Effect of cover on the frequency of occurrence of botanical anomalies and the detection of anomalous radioactivity . - -

7. Statistical measures based on plant sample analyses.........

8. Concentrations of some elements in regolith and rock samples, along with uranium content of branch-tip samples from the

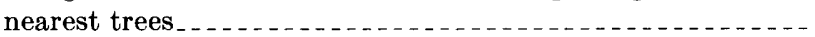

9. Botanical anomalies, their lengths, and the trees that mark the extremities of the anomalies....................

10. Reliability of botanical anomalies and reasons for the ratings

11. Botanical anomaly ratings as to favorableness for uranium ore deposits, and reasons for the ratings . . . . . . . . . . . . 



\title{
BOTANICAL PROSPECTING FOR URANIUM ON THE COLORADO PLATEAU
}

\section{BOTANICAL PROSPEGTING FOR URANIUM ON SOUTH ELK RIDGE, SAN JUAN COUNTY, UTAH}

\author{
By Frank J. Kleinhampl
}

\begin{abstract}
In 1953 and 1954, the plant-analysis prospecting method was used to search for uranium deposits in rocks of the lowest 40 feet of the Chinle formation of Late Triassic age on South Elk Ridge, San Juan County, Utah. The indicatorplant prospecting method was not emphasized because important selenium-indicator plants are absent in the tested area, and because ubiquitous sulfur and calcium in rocks adjacent to the ore zone tend to mask correlations between sulfur- and calcium-indicator plants and uraniferous ground within the ore zone. Collection of plant samples was generally restricted to trees growing in a single line along steep slopes and canyon walls, because only here were trees sufficiently close to the ore-bearing strata to permit successful prospecting.

Sampling results and field relations between sampled plants and geology indicate that in the cool moist areas common on South Elk Ridge many evergreen trees at the sample horizon appear to receive an adequate supply of water from depths no greater than 20 feet. Consequently, for optimum prospecting results, sampled evergreens should grow no more than 20 feet above the ore zone. By inference, this depth restriction is probably applicable wherever similar ecology prevails, as in parts of the Abajo and La Sal Mountains, southeastern Utah. A sample interval of 50 to 60 feet appears to be adequate for delimiting the lateral extent of botanical anomalies.

The normal background content of uranium in some genera of trees appears to differ slightly when uranium is reported in parts per million in plant ash. Recognition of and adjustment for these differences served to define botanical anomalies more sharply or to find new ones by making more precise the definition of an anomalous amount of uranium in the plant samples.

Branch-tip samples, the type generally used in plant-analysis prospecting for uranium, are representative of the trees, and thus are satisfactory in plant-analysis prospecting programs.

Plant-analysis prospecting along 30 linear miles of basal strata of the Chinle formation found 110 localities that are probably mineralized. Based on geologic criteria at the localities, at least 55 could contain minable quantities of uranium.

The success of plant-analysis prospecting at Deer Flat and South Elk Ridge was evaluated in 1955 by tests that included radiometric surveying of holes drilled
\end{abstract}


at botanical anomalies, subsequent chemical analysis of drill core, comparison of overlapping radiometric prospecting and botanical prospecting, and resampling and reanalysis of plants. Plant-analysis prospecting seems to locate as many mineralized localities as does radiometric prospecting, but the methods tend to complement rather than to supersede one another.

According to the more realistic of two interpretations of drill tests, plantanalysis prospecting is about twice as successful as random drilling in locating mineralized material. Closely spaced drilling at botanical anomalies is slightly less successful than similar drilling at geologically selected channel-fillings. Drill tests indicate that amounts of uranium in the rooting medium as small as 10 to $20 \mathrm{ppm}$ locally suffice for trees to absorb unusually large amounts. Because of this and complicating environmental factors, it is impossible to predict reliably the grade and precise extent of deposits.

\section{INTRODUCTION}

Botanical methods of prospecting were used during 1953 and 1954 to search for uranium deposits in the basal 40 feet of the Chinle formation along about 30 linear miles of canyon rims on part of Elk Ridge and adjacent Deer Flat, San Juan County, Utah. About 2,200 samples were collected, mostly from South Elk Ridge. Sampling was done by A. J. Froelich and W. R. Martin in 1953, and by S. A. Bamberg, Lawrence Betzler, and the author in 1954. A few check samples were collected by the author in 1955. Thanks are extended to Tommy L. Finnell, Richard Q. Lewis, Sr., and Helen L. Cannon of the U.S. Geological Survey, who acquainted the author with the geology of the area and the field problems. All work was done by the U.S. Geological Survey on behalf of the Division of Raw Materials of the U.S. Atomic Energy Commission.

The zone selected for testing is the major ore zone in both areas. Both the plant-analysis method and the indicator-plant method of botanical prospecting were tried but only the plant-analysis method proved successful. In this method, branch-tip samples are systematically collected from trees that grow on the unit being prospected. The samples are then analyzed chemically for their uranium content. Trees rooted in mineralized material generally contain an amount of uranium that is detectably more than the amount in trees rooted in barren material.

The present report describes and interprets those relations and features of geology and of botanical prospecting that gave a means of evaluating the Elk Ridge sampling. Summary descriptions of botanical anomalies are included, along with a description of the areal distribution of anomalies at Elk Ridge. Prospectors may find this part useful as a guide to still undiscovered ore deposits. The success of plant-analysis prospecting at Elk Ridge and neighboring Deer Flat is evaluated. 


\section{GEOGRAPHY AND ACCESSIBILITY}

Elk Ridge, an erosional remnant across the crest of the Monument upwarp, is a maturely dissected plateau in central San Juan County, southeastern Utah (fig. 5). The plateau extends across about 20 miles of latitude and 15 miles of longitude. Its top is a gently undulating bench ranging in altitude from 7,000 to about 8,500 feet, above which isolated buttes rise as much as 700 feet.

South Elk Ridge, that part of the plateau lying south of the topographic saddle known as The Notch (Gregory, 1938, p. 10), is embayed by canyons more than 1,000 feet deep; along its southern extremity it rises in a 1,000- to 1,500-foot high escarpment above the Grand Gulch Plateau.

Except in winter, Elk Ridge is easily accessible from Blanding, Utah, on the east, by about 30 miles of dirt road (fig. 5). Two other access roads enter the area from the south and the north. Most parts of South Elk Ridge are accessible by logging roads and roads to mineral claims. Deep snow covers the plateau during winter months, making travel by wheeled vehicle impractical.

\section{GEOLOGY}

The asymmetrical west limb of the Monument upwarp dips $1^{\circ}-2^{\circ}$ westward; its east limb dips as much as $20^{\circ}$ eastward, where erosion of the upwarp has defined the Comb Ridge monocline (Baker, 1935, fig. 2). Minor flexures of the upwarp show in the rocks exposed at the top of the plateau. Faults are uncommon on South Elk Ridge. This part of the plateau is underlain mostly by gently dipping sedimentary rocks that range in age from Early Permian to Late Triassic (Gregory, 1938, p. 36-54; and Richard Q. Lewis, Sr., and William J. Krummel, Jr., written communication, 1954). The nearest exposed igneous rocks are 7 miles to the east in the Abajo Mountains.

A brief description of some of the Permian rocks is essential to an understanding of plant distribution at Elk Ridge. More detailed descriptions appear in a report by Gregory (1938, p. 41-47). The Cedar Mesa sandstone member of the Cutler formation is about 1,100 feet thick at South Elk Ridge and forms the lower part of many canyons. This member consists of predominantly massive buff to white finegrained sandstone interstratified with some red-brown shale. Overlying the Cedar Mesa member is the Organ Rock member of the Cutler formation, consisting of reddish-brown thin-bedded siltstone and very fine grained sandstone. This unit is approximately 300 feet thick (Lewis and Krummel, written communication, 1954).

The Moenkopi formation of Triassic(?) and Early and Middle(?) Triassic age overlies the Permian rocks. The Moenkopi consists of 


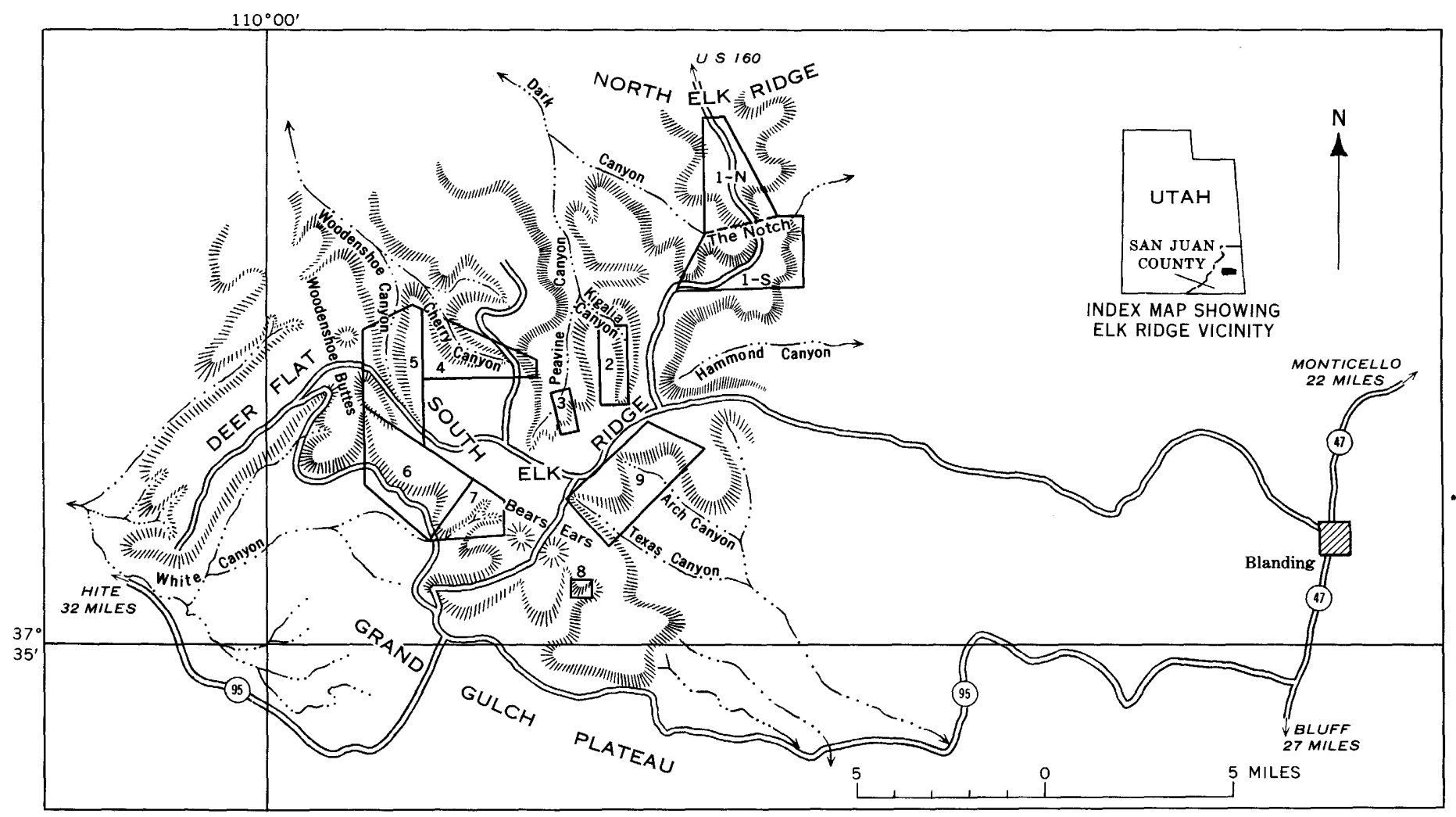


265 to 415 feet of reddish-brown micaceous shale and thin-bedded siltstone and red to buff fine-grained sandstone. The basal member is the Hoskinnini member, which is 65 feet thick (Lewis and Krummel, written communication, 1954) and which once was considered to be a member of the underlying Cutler formation, but has since been redesignated by Stewart (1959, p. 1852-1868).

Unconformably overlying the Moenkopi are 700 to 900 feet of strata of the Chinle formation of Late Triassic age. Three distinct units are generally recognized within the lowest 200 to 300 feet of the Chinle of South Elk Ridge; they are, from bottom to top, a sandstone unit, occurring as discrete lenses, a bentonitic claystone and clayey sandstone unit, and the Moss Back member of the Chinle formation. According to Lewis and Campbell $(1959 \mathrm{a}, \mathrm{b})$, the basal sandstone lenses are correlative, at least in part, with the Shinarump member of the Chinle formation in the Deer Flat and White Canyon areas just southwest of Elk Ridge, and will be so correlated for purposes of discussion in this report. The unnamed overlying bentonitic claystone unit, termed the lower part of the Chinle formation by Lewis and Campbell $(1959 \mathrm{a}, \mathrm{b})$, is referred to in this report as the Monitor Butte member for facility of discussion and because some workers correlate the unit with the Monitor Butte member (Stewart, 1957, p. 442 and 452 ).

The Shinarump member of the Chinle formation is discontinuous, with a maximum thickness of about 60 feet (Lewis and Krummel, written communication, 1954). It grades upward from coarsethrough fine-grained sandstone into the gray and yellow mudstone and claystone of the overlying unit. In places, the Shinarump is a nearly homogeneous massive ledge forming sandstone. At other places, sparse to abundant thin lenses of conglomerate, siltstone, and shale are present in the sandstone. The Shinarump generally crops out as very broad thin lenses, which in their entirety probably do not fill channels, but which represent filled swales in the Moenkopi similar to those in Monument Valley, Arizona (Witkind, 1956, p. 115-116). At South Elk Ridge, channels occur both away from inferred swales and locally in them. The Shinarump is thickened where it fills channels cut in the top of the Moenkopi formation. Coaly material and bitumen (Rice, 1949, p. 43 and 79) are present locally in the Shinarump and the immediately overlying strata, particularly in sandstone and conglomerate, and occur as disseminated and aggregated very fine grained particles, films, and seams. Some coaly material occurs as pods and as large plant fragments.

The Monitor Butte member of the Chinle ranges in thickness from about 100 to 150 feet. It consists of claystone and clayey sandstone 
interstratified with lenses of sandstone (Stewart, 1957, p. 452) and of siltstone. The overlying Moss Back member is a resistant unit that caps most of South Elk Ridge and that ranges in thickness from about 70 to 100 feet. The remainder of the Chinle consists of about 500 to 600 feet of claystone, calcareous siltstone, sandstone, and, in its lower part, limestone. Most of the rocks above the Moss Back have been eroded away but the slope-forming upper part of the Chinle crops out in isolated buttes such as the Bears Ears (fig. 5), which are capped by the Wingate sandstone of Late Triassic age.

\section{ORE DEPOSITS}

Uranium deposits on Elk Ridge occur in the Moenkopi formation and the Shinarump, Monitor Butte, and Moss Back members of the Chinle formation. Botanical prospecting for uranium was restricted to strata within the lowest 40 feet of the Chinle formation because this zone is the important ore zone in the area, as well as at adjacent Deer Flat. Most of the known ore deposits of South Elk Ridge are localized in the lowest part of the Chinle where it fills channels cut in the Moenkopi. Ore deposits of the Chinle on South Elk Ridge are probably similar in size and shape to those at adjacent Deer Flat, where the host rock has similar sedimentary and lithologic features. At Deer Flat the largest fusiform body is about 2 feet thick, 9 feet wide, and 25 feet long, and the largest tabular body is about 14 feet thick, 150 feet wide, and 250 feet long (Finnell and others, 1962).

Weakly mineralized rock generally occurs around the ore deposits and in some localities extends considerable distances from them. For example, radioactivity of more than background intensity was noted in the lowest part of the Chinle, extending continuously along some outcrops where there are only a few scattered ore-grade pods only a few inches to a few feet in maximum dimensions. Also, at some places ore-grade deposits are restricted to a single lens in a vertical sequence of weakly mineralized lenses of shale, siltstone, or sandstone. Such distributions of ore minerals fit "dispersion patterns" that have been classified genetically as either primary or secondary by Fersman (1939 [p. 3 of translation]) and Hawkes (1954, p. 54-56).

Although it is difficult to classify most of the patterns on Elk Ridge genetically, some secondary dispersion halos must exist because plants in the vicinity of the known uranium deposits contain anomalously large amounts of uranium. The uranium entered the plant through water or soil colloids which contain, in effect, secondarily dispersed uranium.

Observations pertaining to present-day ground-water circulation on South Elk Ridge bear this out. Water sometimes circulates above 
the Moenkopi in the lowest few feet of massive sandstones of the lowest Chinle. This is evident from coatings of white soluble salts (probably chlorides, sulfates, and carbonates of magnesium, sodium, and calcium) or moisture seen on rocks exposed at the base of sandstone in the lowest part of the Chinle. The salt deposits are due to evaporation of the ground water which contains dissotved salts. Such intermittent seeps occur locally at the contact of the Moenkopi and Chinle where thick porous and permeable sandstone of the basal part of the Chinle overlies the relatively less permeable Moenkopi.

Because ground water in the area is supplied by downward-percolating water and passes at times through the sandstones to the bottom few feet of units that locally contain uranium deposits, it is reasonable to conclude that one effect of the circulation is to increase laterally and decrease vertically any dispersion halos, causing a concentrated layer of ore-derived minerals to form along and mostly just above relatively impermeable rocks. Such distributions are noted at some outcrops where the lower part of the Chinle is mineralized, but the recharge area of the basal sandstones of the Chinle cannot be very great because of overlying impermeable strata and this makes unlikely a widely distributed secondary dispersion halo. R. Q. Lewis, Sr., and R. H. Campbell (written and oral communications, 1958), who examined mines of the area as late as 1957 , have said that the mines are fairly dry and contain chiefly primary minerals that at most places are in the upper part of basal sandstones of the Chinle formation and are invariably overlain by relatively less permeable rocks such as mudstone or very argillaceous sandstone. Their observations seem to indicate that present-day ground-water circulation in the lowest Chinle rocks away from their outcrops has not greatly affected any older dispersion halos.

Uranium is generally associated with copper in the Shinarump member and related units on Elk Ridge and adjacent Deer Flat (Weeks and Thompson, 1954; Gruner and Gardiner, 1952, p. 18-19; Finnell and others, 1962; and Lewis and Krummel, written communication, 1954). The copper occurs in the deposits in chalcocite, chalcopyrite, malachite, and azurite. Iron, in the form of pyrite, is abundant locally in some of the deposits. The vanadium content of the deposits is very small (table 1 ).

Uranium minerals are invariably associated with carbon, which occurs as coaly material in seams, along fractures, and disseminated in siltstone, sandstone, and conglomerate, or as bitumen in blebs and coatings on grains in siltstone, sandstone, and conglomerate. The identified uranium minerals include uraninite, uranophane, autunite, metazeunerite, schroeckingerite, and bayleyite. 
Many of these uranium minerals are soluble in water and weak sulfuric acid (Weeks, 1956, p. 527; Katz and Rabinowitch, 1951, p. 75 and 89 ), both of which are likely to be present occasionally at some of the near surface uranium deposits in the area (Froelich and Kleinhampl, 1960, p. 79). These solubilities strengthen the postulate of extensive near-surface dispersion of uranium minerals at. South Elk Ridge, as does the known ease of movement of oxidized uranium in nonvanadiferous deposits (Garrels and Christ, 1956).

\section{GUIDES TO ORE}

Most of the geologic criteria used as guides to uranium deposits at South Elk Ridge are listed by Trites and Chew (1955, p. 247-248) and Finnell and others (1962). Lithology, sedimentary structures, visible ore minerals, and intensity of radioactivity have all been used to rate the rocks as to their favorableness for containing ore deposits.

Units considered most favorable for containing uranium ore deposits fill channels cut into the Moenkopi or have intrachannel-fill scours confined by relatively impermeable beds. In general, rocks of the Shinarump member and related rocks more than about 10 feet thick are considered most favorable for containing channel-fill structures and, therefore, are favorable for containing ore deposits. At many places cover obscures the relations of the channels, and other criteria are more useful in classifying strata as to favorableness. Relatively thick-bedded massive cross-stratified or horizontal strata ${ }^{1}$ are considered favorable if they are lenticular and are composed of poorly sorted silty and conglomeratic sandstone and siltstone or if they contain lenticular gray mudstone. The least favorable units seem to be sequences of interstratified silty sandstone and siltstone where the bedding and splitting are characteristically regular and thin. Observations indicate that this type of rock is generally barren or only weakly mineralized, particularly where it is a mottled white and light purplish red.

Some of the guides to ore, such as intensity of radioactivity and visible ore minerals, can be used to estimate extent, kind, and degree of mineralization. Because of secondary halos, however, these guides may lead to erroneous estimates, and, as guides to ore, are contingent upon favorable lithology and sedimentry structures of the basal rocks of the Chinle formation. Some guides, such as anomalous radioactivity, were noted only after ascertaining the presence of a botanical anomaly, which itself indicates the presence of anomalously large amounts of uranium. Mineralized parts of the lower Chinle lying

\footnotetext{
1 Terminology for stratification and splitting used in this report is that given by McKee and Weir (1953).
} 
above the ore zone were used in some places as a guide to ore at the base of the Chinle, but this guide seems to a poor one. A lack of outcrops generally prevented the full utilization of the ore guides.

Included in the section of this paper describing botanical anomalies is a table which summarizes for most botanical anomalies the host rock's favorableness for ore and the bases for these ratings. Comparisons of ratings generally can be made among the anomalies within a subarea, but comparisons among anomalies of different subareas are not so valid.

\section{PLANT ECOLOGY}

Some knowledge of plant ecology is important for the successful completion of a botanical-prospecting program in any area. Ecology affects the selection of a botanical-prospecting method as well as the details of procedure to be followed in using the method. This section of the report describes the types of vegetation at Elk Ridge and their interrelations to climate and topography. The effects of groundwater supply and the rooting medium on the success of plant prospecting are so important that they are discussed in more detail in other parts of the text.

Vegetation of the Elk Ridge area can be classified into two chief forest types, each of which is a climatic climax formation. The climax is defined as a relatively stable phase reached by continuous change in vegetation types (Tansley, 1935, p. 306). It is the highest type of vegetation possible with an existing climate (Weaver and Clements, 1938, p. 478). For example, the Rocky Mountain woodland climax, present in the Elk Ridge area, is adjusted to a climate with less precipitation and greater temperature and length of growing season than that of the Rocky Mountain montane climax, also present in the area (Weaver and Clements, 1938, p. 472).

In general, the Petran montane climax forest (Weaver and Clements, 1938, p. 505-507) is characteristic of the upper parts of Elk Ridge, where its presence indicates an annual precipitation ranging from about 18 to 23 inches. Major dominants of this climax are ponderosa pine, Douglasfir and white fir. Douglasfir and white fir occur chiefly as nearly pure stands on north-facing slopes, and ponderosa pine as nearly pure stands on the top of the plateau. The ponderosa forest is relatively open and has moderately well-developed shrub and grass layers. Common shrubs are saskatoon serviceberry, mountain snowberry, Gambel oak, and, locally, antelope bitterbrush, a holly grape, and the same plants that comprise the subdominants in the woodland climax. Common juniper grows locally in the montane forest. 
In the southwestern part of the plateau, near Burch and Woodenshoe Canyons, big sagebrush intermixed with ponderosa pine probably indicates an annual precipitation ranging from about 15 to 18 inches (Weaver and Clements, 1938, p. 506 and 534; Woodbury, 1947, p. 122 and 124). The presence of the sagebrush, which locally forms nearly pure stands, is considered to be due to the removal of climax plants. That some of this area is within the montane forest climax zone is indicated by the presence of mature, isolated ponderosa pines. Logging or burning of ponderosa pine and (or) overgrazing, which prevents growth of new pine seedlings and good grass cover, probably preceded the ingress of sagebrush. Left to natural circumstances, vegetation in this area would probably revert to ponderosa pine forest and grassland. Generally the Douglasfir and white fir forests form such dense stands as to restrict the development of shrub and grass layers. Some Rocky Mountain maple and a water birch(?) grow locally in open moist places. Quaking aspen is abundant in some localities on the top of the plateau, on slopes at the heads of some northfacing reentrants, and in the bottoms of some steep gullies that extend nearly to the top of the plateau. The aspen is probably a subclimax due to burning and logging of the climax forests.

The lower parts of Elk Ridge are covered by the woodland climax and an oak-mountainmahogany zone. The former is characterized by the Colorado pinyon pine, Utah juniper, and oneseed juniper. Some Rocky Mountain juniper grows in the more moist part of the woodland climax. Subdominants in the woodland climax community include mountainmahogany, apacheplume, and greenleaf manzanita. The herb and grass layers are typical of the woodland community. Gregory $(1938$, p. 23-26) gives a long list of plants found at Elk Ridge and adjacent areas. Daubenmire $(1943$, p. 340$)$ places the pinyonjuniper zone between the ponderosa pine and the oak-mountainmahogany communities, but locally at South Elk Ridge the pinyon-juniper zone is so poorly developed as to be practically nonexistent.

The montane forest generally forms a sharp boundary or very narrow transition zone (fig. 6) with the lower communities. This boundary or zone is useful in locating the contact of the Moenkopi and Chinle formations, because at many places between the altitudes of 8,200 and 8,600 feet the contact and boundary coincide. Some nearly pure patches of fir, maple, or aspen are also useful in this respect because they either occur along spring lines at the base of the sandstones in the lowest part of the Chinle or grow on these same units where they are concealed by overburden. The factor controlling the location of the lower boundary of the montane forest and the location of the nearly pure patches of fir, maple, and aspen is chiefly 
that of available water. The generally porous and permeable rocks in the basal part of the Chinle provide pore water and, locally, perched water greatly in excess of that available from the underlying Moenkopi; thus different types of vegetation grow on the rock units.

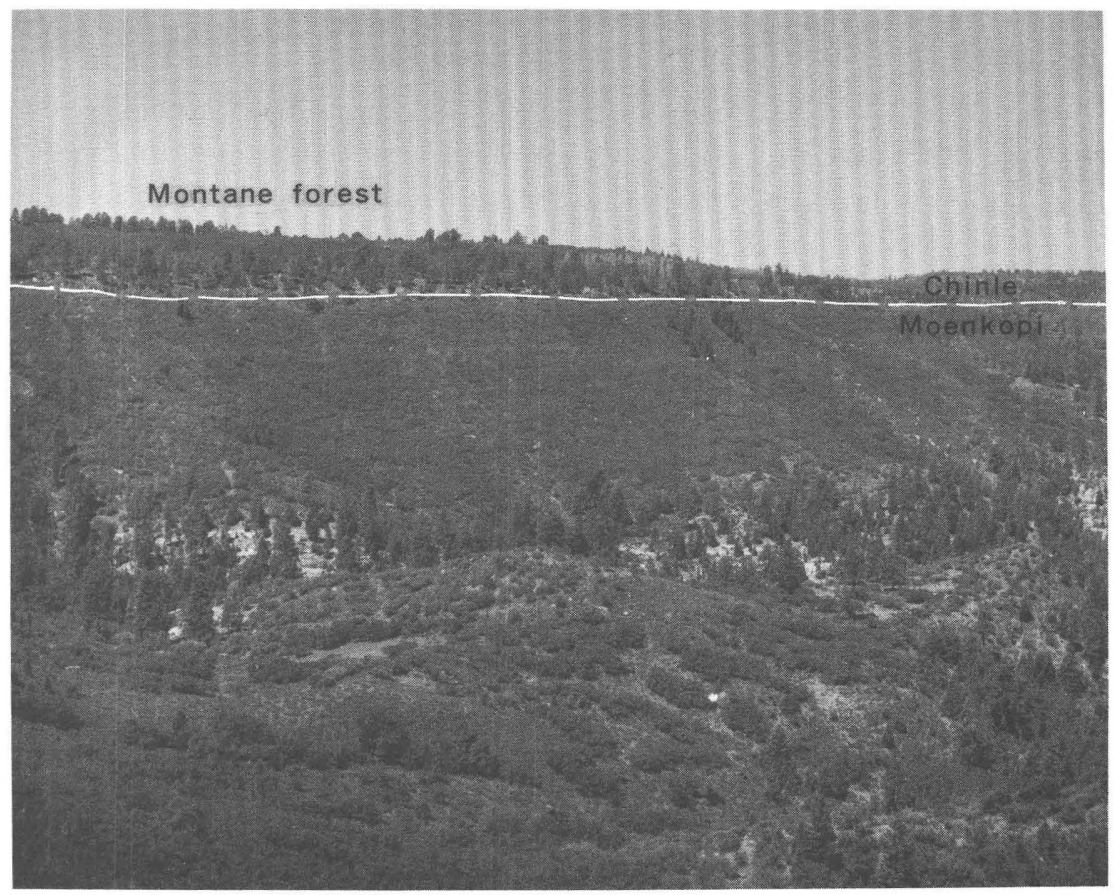

Figure 6.-View looking west across Dark Canyon from The Notch, showing the sharp boundary between the upper montane and the lower plant communities, and the relation of the boundary to the contact of the Moenkopi and Chinle formations. Dashed line demarcates lower limit of montane forest and the approximate contact of the Moenkopi and Chinle formations.

Exceptions to a sharp boundary between the climax communities occur on slopes receiving large annual amounts of heat energy, which effectively makes the environment more arid (Cottle, 1932, p. 121-134). The most arid slopes are those having a south-facing component, because here the sun's rays are most direct and longest lasting. At these places, ponderosa pine, the dominant in the montane forest climax requiring the least moisture (Weaver and Clements, 1938, p. 506), may be intermixed with pinyons and junipers throughout a wide zone.

Commonly on Elk Ridge there are places where the usual positions of plant communities are abruptly changed with respect to one another. Montane forest extends completely down some north-facing slopes and is replaced laterally and abruptly by the woodland climax. $6274700-62 \longrightarrow 3$ 
Patches of montane forest, and even spruce trees, which require more moisture and cooler climates for growth than do the Douglasfir and white fir, occur in deep gullies, well below their normal positions, where lack of sunshine and (or) cold air drainage from the plateau top provides optimum growing conditions.

According to definition, climatic climax formations of plants are controlled by climate, which, in turn, is controlled by a number of factors. At Elk Ridge the major local factor controlling climate is altitude but there are other local controls, such as the slope-facing direction, slope angle, and air currents. The factors of angle and direction of slope principally affect the amount of runoff and insolation. Air currents chiefly affect temperature and transpiration. To the extent that all these factors affect the amount of water available to plants and the movement of water into and out of plants, they are related. Lithology, like climate, affects the amount of available moisture and thus may locally affect the distribution of climax associations.

The effect of altitude on climate is best seen in the contrasting climax associations of the flat open high parts of Elk Ridge and in the low surrounding areas, such as the Grand Gulch Plateau. Montane forest dominates the top of Elk Ridge and the woodland climax dominates the low surrounding areas. Local irregularities in this distribution order at Elk Ridge indicate that factors other than altitude have superposed controls on climate.

Along the north-facing slope of Cherry Canyon, for example, the climate has a degree of coolness and moistness equivalent to that found at or slightly above the flat top of Elk Ridge. Such a climate is indicated by dense stands of Douglasfir and white fir, which require more moisture than ponderosa pine. Other observations suggest that here slope-facing direction and slope angle chiefly control climate by greatly reducing insolation. First, fir forests grow on both sandstone and shale units, indicating the subordinate nature of the lithologic control of moisture; and second, dissimilarity of vegetation at the same altitude on the north- and south-facing slopes of the canyon indicate that insolation effects dominate those of cold air drainage into the canyon from the plateau top. Woodland climax vegetation interspersed with some ponderosa pine and Douglasfir forms the chief cover on the south-facing slope.

In other parts of Elk Ridge, the importance of the lithologic factor in determining vegetation type is greater. This is well illustrated in Dark Canyon (fig. 6), where a sharp boundary between the upper montane forest and lower plant communities generally coincides with the base of the Chinle formation. Basal units of the Chinle consist 
of poorly sorted sandstone and siltstone that contain more available moisture than the underlying shale and siltstone of the Moenkopi formation. The effect of altitude must locally dominate that of lithology, however, because at places the lower plant communities extend up across the contact of the major rock units. Three factors, lithology, insolation, and the increased amount of water available in runoff, together account for the stand of ponderosa pine that grows in a seemingly incongruous position at the bottom of Dark Canyon well below the normally positioned montane forest (fig. 6). The ponderosa pines grow on the Cedar Mesa sandstone member of the Cutler formation (white areas in middle foreground of figure 6 mark approximate top of the member), where more moisture is available than in the overlying clayey and silty members of the Cutler. The steepened slope, formed by the cliff-forming Cedar Mesa sandstone member, provides more protection from insolation than the overlying more gentle slope, and trees of the montane forest growing in the canyon bottom form their most dense stands on and below cliffs, particularly those cliffs having a north-facing component.

\section{BOTANICAL PROSPECTING}

Two common methods of botanical prospecting were considered initially for prospecting at South Elk Ridge. Both methods, indicatorplant and plant-analysis prospecting, are dependent on the availability of uranium or associated elements to the roots of the plants, either through direct rooting of the plants in uraniferous material, or through access to these elements in vadose and ground waters. Thus the primary and secondary dispersion halos around uranium ore deposits (described on p. 110) could increase the size of the targets in botanical prospecting beyond the size of the ore deposit itself. At South Elk Ridge botanical prospecting is restricted to that part of the Chinle formation at and just back of the outcrops; therefore, the observation by Lewis and Campbell (see p. 111) that away from outcrops the dispersion halos have not been greatly affected by present-day ground-water circulation has little relation to the use of the prospecting methods.

Determinations of plant copper content might supplement the uranium-in-plant determinations that are used in locating uranium deposits at South Elk Ridge and adjacent Deer Flat. Copper is about three times more abundant in uranium mineralized sandstones than in barren sandstones of Late Triassic age (Shoemaker and others, 1955 , p. 49). The effectiveness of the copper-in-plant method in locating uranium deposits has not yet been completely evaluated, and will not be discussed in this report. 


\section{INDICATOR PLANTS}

Most of the indicator plants listed by Cannon $(1952,1954)$ that were found at South Elk Ridge bore no apparent relation to mineralized rocks or to botanical anomalies located by plant-analysis prospecting. Astragalus, species of which are the best selenium-indicators, was not seen. Sulfur- and calcium-indicator plants, less reliable than most selenium indicators, were generally useless in prospecting because sulfur and calcium are ubiquitous in the rocks at and immediately above the tested horizon, and thus mask sources of these elements in the uranium deposits. Indicator and uranium-tolerant plants reported (Helen L. Cannon, oral communication, 1954) in the vicinity of the mineralized parts of the Shinarump member of the Chinle formation include Indian ricegrass, rock goldenrod, a paintedcup (paintbrush), Stansbury cliffrose, and an eriogonum. Most of these and the segolily mariposa and an onion have been seen by the author, but all also grow on barren rocks in the area. One place where onions grow in profusion deserves additional description because the location is about 225 feet above the known ore horizon and away from any obvious localized source of sulfur. This onion locality, in the extreme northeastern part of the studied area (in unsurveyed NE1/4 sec. 36 , T. 34 S., R. 19 E.), is more completely described in a later section of this report because of the locality's coincidence with trees that contain anomalously large amounts of uranium.

A scarcity of the best indicator plants at and above the altitude of the tested horizon appears to be attributable chiefly to the cold moist climate. The tested horizon at Elk Ridge ranges in altitude from about 7,600 to about 8,600 feet, and only that part near Burch Canyon has a climate similar to that of the usual warm arid habitat of the known indicator plants (Cannon, 1954, p. 218 and 219). Another factor that would inhibit the growth of good selenium indicators is a deficiency of available selenium, and at Elk Ridge only small, perhaps unavailable, amounts are known to occur in the uranium deposits (table 1 and Froelich and Kleinhampl, 1960, p. 52, 54 and 60$)$.

\section{PLANT-ANALYSIS PROSPECTING}

\section{BOTANICAL ANOMALIES}

Trees containing anomalous uranium indicate localities underlain by anomalous amounts of uranium. These places are termed botanical anomalies. Botanical anomalies within each subarea (pl. 9 and table 9) are briefly described in another part of this report.

All reliable anomalies contain anomalously large amounts of ura- 
TABLE 1.- Analyses of grab samples of mineralized rock from the Shinarump member of the Chinle formation at different localities on Elk Ridge, San Juan County, Utah

[Analysts: S. Furman, J. S. Wahlberg. R. C. Tripp, R. G. Havens, C. E. Thompson, and J. Siverley, U. S. Geological Survey]

\begin{tabular}{|c|c|c|c|c|c|c|c|}
\hline \multirow{2}{*}{ Sample No. } & \multicolumn{2}{|c|}{ Locality } & \multirow{2}{*}{$\begin{array}{c}\mathrm{eU} \\
\text { (percent) }\end{array}$} & \multirow{2}{*}{$\begin{array}{c}U \\
\text { (percent) }\end{array}$} & \multirow{2}{*}{$\begin{array}{c}\mathrm{V}_{2} \mathrm{O}_{5} \\
\text { (percent) }\end{array}$} & \multirow{2}{*}{$\begin{array}{c}\mathrm{Se} \\
(\mathrm{ppm})\end{array}$} & \multirow{2}{*}{$\underset{(\mathrm{ppm})}{\mathrm{Cu}}$} \\
\hline & $\begin{array}{l}\text { Botanical } \\
\text { anomaly }\end{array}$ & Subarea & & & & & \\
\hline AJF-53-978 & 6 & 5 & 0.16 & 0.11 & $<0.05$ & 4 & $>4,000$ \\
\hline AJF-53-979 & $\begin{array}{l}\text { Few hundred } \mathrm{ft} \\
\text { south of } 6 \text {. }\end{array}$ & 7 & .047 & .016 & $<.05$ & $<2$ & 1,500 \\
\hline AJF-53-980 & 23 & $1 \mathrm{~N}$. & .14 & .14 & $<.05$ & $<2$ & 1,000 \\
\hline AJF-53-983 & 25 & $1 \mathrm{~N}$. & .31 & .22 & $<.05$ & 2 & 300 \\
\hline $522-12$ & At or near 32-- & $1 \mathrm{~N}$. & .018 & .022 & $\cdots$ & $<.1$ & $\cdots$ \\
\hline AJF-53-981 & 32 & $1 \mathrm{~N}$. & .078 & .073 & $<.05$ & 2 & 50 \\
\hline AJF-53-982 & 32 & $1 \mathrm{~N}$. & .061 & .068 & $<.05$ & $<2$ & 100 \\
\hline
\end{tabular}

${ }^{1}$ AJF samples collected by A. J. Froelich; sample 522-12 collected by H. L. Cannon.

nium in the rooting medium. Where trees contain indeterminately anomalous uranium, the botanical anomalies are of indeterminate reliability. Botanical anomalies become increasingly reliable with an increase in number of trees defining them, with a closer grouping of the trees, with a greater contrast between the reliably anomalous uranium contents of the defining trees and the background contents of trees adjacent to the locality, and with increased numbers of confirming resamples and reanalyses of portions of the original sample. An apparent botanical anomaly is one defined by trees whose anomalous uranium contents reasonably can be attributed to some contamination factor, as anomaly 6 , subarea 5 (table 9 ). Contamination masks the real effects of the rooting medium, making it difficult to assign a more useful anomaly classification. All these factors have been used to classify the reliability of botanical anomalies found at Elk Ridge.

Botanical anomalies are also rated in this report as to their favorableness for containing minable quantities of uranium. (See section "Guides to ore".) Those anomalies with the best favorableness ratings for containing ore deposits deserve the highest priority in any exploration plans.

The boundaries of a botanical anomaly are partly arbitrary; some elongate ones might be divided into two or more shorter ones. Boundaries are generally placed at the limit of all adjacent or closely spaced samples that contain more than background amounts of uranium (table 3), and, as a result, may inadvertently include a few samples containing background amounts of uranium. To facilitate the comparison of botanical anomalies, direct measurement of their linear extent is made wherever possible. Those anomalies defined by only one tree or by irregularly spaced trees require different treatment to obtain their linear extents. The area tapped by a tree's 
roots provides a measure of linear extent. At south Elk Ridge, some trees of the kinds and sizes composing the bulk of sampled types had exposed roots extending a maximum of about 25 feet laterally from the trunk. For the purpose of determining anomaly length, therefore, a tree's surface roots were considered to tap an area in the form of a circle having a radius of 25 feet measured from the tree trunk. Studies of botanists (Woodbury, 1947, p. 116) indicate that such an area is reasonable. The area actually tapped depends on many factors, such as the species and duration of growth of a tree, density of trees, and the position and amount of available water. For this reason, anomaly length does not necessarily coincide with the actual extent of mineralized ground. A more important reason for lack of coincidence is that the length may reflect the effect of ground-water circulation, which exaggerates the extent. Thus, boundaries of botanical anomalies generally include some barren ground, but do not exclude actual mineralized ground.

\section{SAMPLE TYPE, INTERVAL, AND HORIZON}

The tested parts of Elk Ridge are treated as nine subareas (pl. 9) in this report because sampled parts are either separated by unsampled parts or have special geologic or botanical features. One quart of branch tips, which includes twigs and needles, was collected from the entire periphery of each sampled plant. Thirteen kinds of trees and shrubs were sampled because no one kind consistently occurs at the sample horizon. Plants sampled included ponderosa and Colorado pinyon pines; Douglasfir and white fir; oneseed, Rocky Mountain, Utah, and common junipers, mountainmahogany, manzanita; Rocky Mountain maple; quaking aspen and Gambel oak. Generally only a few kinds of plants were sampled within a single subarea. Different kinds of plants that were growing close together were sampled so that they could be compared for their uranium and ash contents.

The sample interval and horizon were selected on the basis of experience of other workers on the Colorado Plateau. Suitability was confirmed by experimental sampling and by observations of the discontinuity of the massive sandstone lenses at the base of the Chinle and of the size of uranium deposits and dispersion halos. A sample interval of 50 to 60 feet was used along covered intervals or poor exposures of rocks at the base of the Chinle. Almost no samples were collected along excellent exposures of these rocks where scintillometer tests of the units indicated intense radioactivity; but a few samples were collected for control purposes to compare the intensity of radioactivity and the amounts of uranium in plants. The sample interval used seems to be in accord with the general features of both 
dispersion halos around the uranium deposits and the effects of present-day ground-water movements on the halos. Also, based on actual testing, the sample interval was found generally to be satisfactory.

Based on the observations of factors influencing the choice of a sample interval, it appears that no significant deposit should have been missed as a result of the sample interval chosen. This choice on Elk Ridge is of less importance than the choice of a sample horizon, which, if injudiciously chosen, could easily miss a deposit.

The major ore-bearing sandstones lie about 150 to 300 feet below the top of the plateau and crop out locally along steep slopes of canyons. Plant sampling had to be confined mainly to a single line near the top of the sandstones, because only a few feet back from the cliff the great thickness of overlying strata make depth to the ore zone too great for successful prospecting. The sample horizon ranges upwards from the top of the Moenkopi formation to about 40 feet above the top and averages about 20 feet above.

A study to determine the optimum position of a sample horizon was difficult to make because two mutually exclusive factors existed at the places most suited for such a study. One factor, contamination of plants, is detrimental to the test. Contamination generally occurred in well-prospected localities where the helpful second factor, the extent of mineralized rock, was best known. As a corollary, where contamination did not occur prospecting generally had not progressed enough to know adequately the disposition of uranium.

Field observations show empirically, however, that tree samples generally contain only background amounts of uranium where the trees grow more than about 20 feet above uranium deposits. Exceptions do occur. For example, at one place (fig. 7) some trees containing anomalously large amounts of uranium grow along a horizon about 20 feet above the position of inferred uranium deposits at the base of the Chinle formation.

Where exceptions are found, other trees, sampled lower and closer to the inferred deposits generally contain great or even greater amounts of uranium than the higher trees. No single good example demonstrated this relation but several poor ones at least suggest it.

At other places such as at botanical anomalies 11 and 12, subarea 1-S (fig. 8), a different relation exists. In the examples, trees contain anomalously large amounts of uranium where they grow in rocks of the Monitor Butte member of the Chinle formation about 45 feet above the base of the Chinle, which is the usually inferred position of mineralized material. But most samples collected from trees at a horizon closer to the inferred mineralized zone contain only normal amounts 


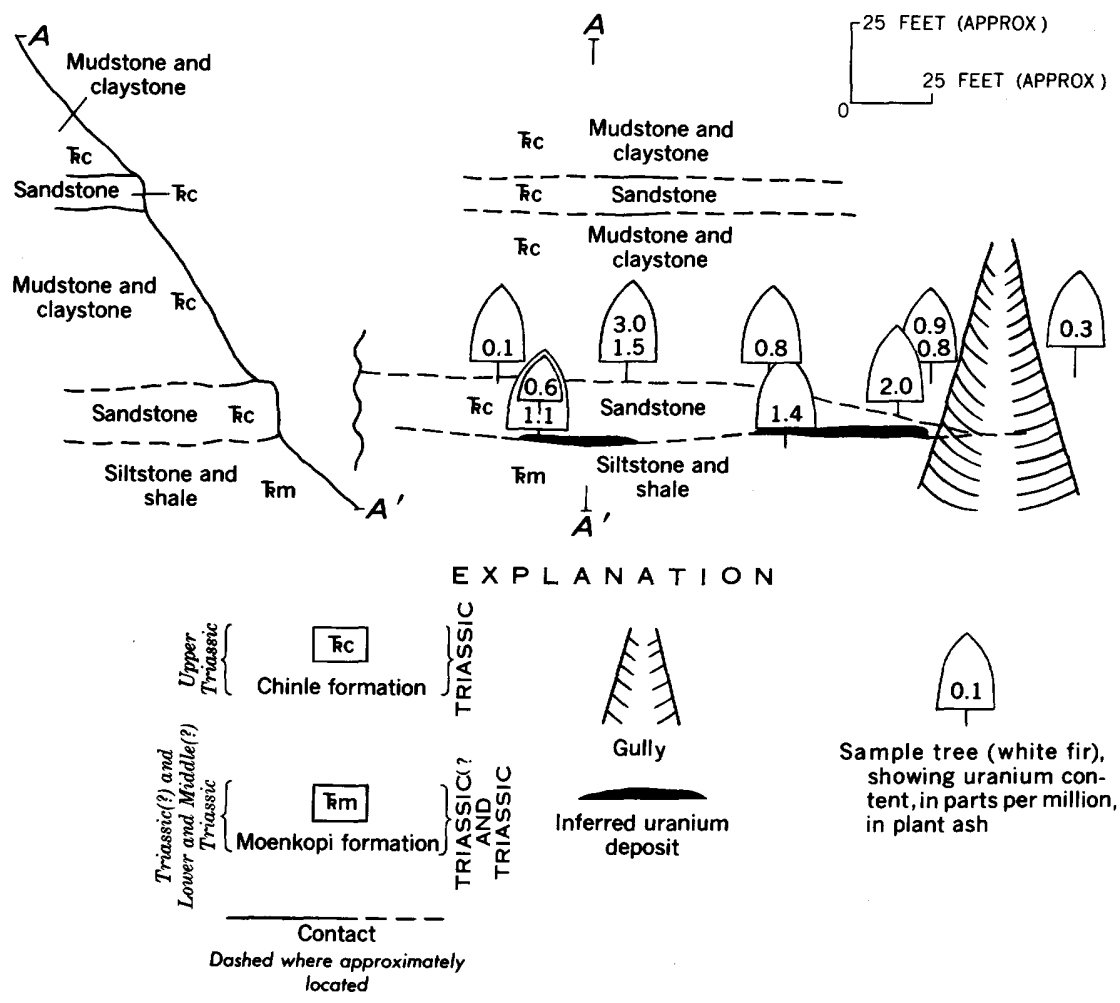

FIGURE 7.--Sketched longitudinal profile, looking south at slope, and a cross section of the slope at botanical anomaly 5, subarea 4, showing relations of tree samples and geology, South Elk Ridge, San Juan County, Utah.

of uranium. Such discrepancies are often attributable chiefly to a lack of uranium in the lower zone and to the presence of uranium higher up in the Monitor Butte member and the upper part of the Shinarump member of the Chinle formation. A high sample horizon, then, most likely will either find no uranium deposits or will lead to the discovery of uranium that may or may not be related to ore deposits.

Considering the habits of the ore deposits of South Elk Ridge, the best sample horizon is that which will test the sandstone at the base of the Chinle formation and plant-analysis prospecting indicates that this sample horizon lies no more than 20 feet above, and in some places at, the top of the Moenkopi formation.

At South Elk Ridge, then, 20 feet is the effective depth of root penetration, which is defined as the maximum depth at which most sampled trees in an area will define mineral deposits. For any area, this depth is a function of the factors of mineral dispersion and the 


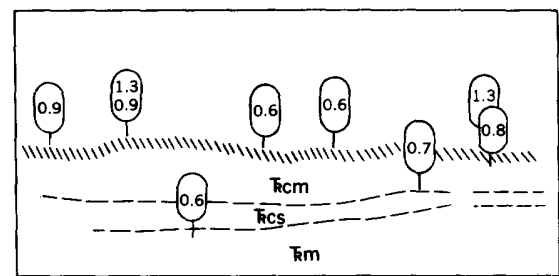

$A$
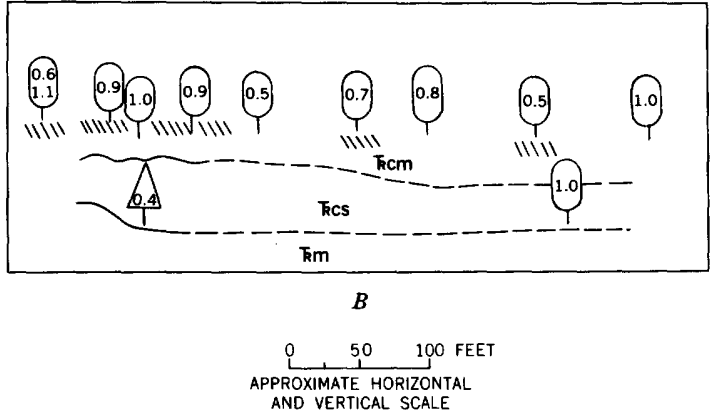

EXPLANATION

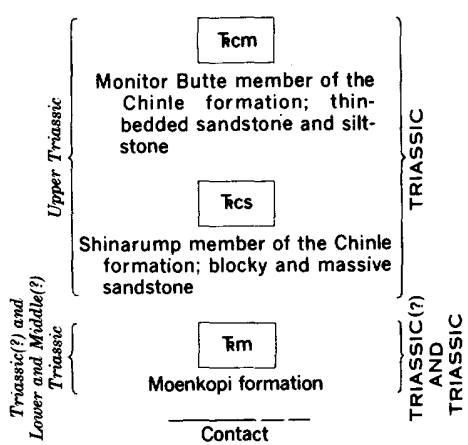

Doshed where indefinite

11111111111

Top of topographic bench

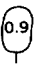

Ponderosa pine tree and uranium content of sample, in parts per million, in plant ash

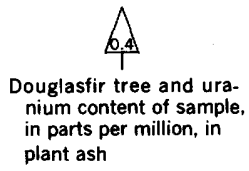

FigURE 8.--Sketched longitudinal profiles at botanical anomalies showing relations of tree samples and geology, South Elk Ridge, San Juan County, Utah. $A$, Northeastfacing slope at botanical anomaly 11, subarea 1-S: $B$, northeast-facing slope at botanical anomaly 12, subarea 1-S.

actual depth of root penetration. A measure of either factor is less useful in plant-analysis prospecting than a measure of the effective penetration depth. Fortunately, at most places, empirical observation of sample results makes it easier to measure the effective penetration depth than to measure either component.

On South Elk Ridge the sample horizon along covered slopes was located from spatial relations and guide features of the nearest outcrops, topographic breaks in slope, and from fragments of the Shinarump member of the Chinle formation in the colluvium. A sharp topographic break, present in parts of the area, marks resistant strata in the lowest part of the Chinle and is about 10 to 25 feet above the top of the basal massive sandstones. The resistant strata upon which the bench is developed typically consist of sandy siltstone and some thin lenses of medium- to coarse-grained hematitic sandstone. The siltstone is thin bedded, well cemented, and characterized by white to light-gray and mottled white and purple coloration and (or) abundant minute irregular fractures. A poorly developed topographic 
break, generally lying within the upper 40 feet of the Moenkopi formation, is present in parts of the area and serves as an additional guide to the location of the sample horizon.

\section{URANIUM CONTENT OF TRGES AND BOTANICAL ANOMALIES}

At Deer Flat, Utah, Froelich and Kleinhampl (1960, p. 59) consider evergreens containing less than $1.0 \mathrm{ppm}$ uranium in the plant ash of their branch tips as having background uranium contents. Empirical observation of the uranium-in-plant analyses from South Elk Ridge partly confirms this $1.0 \mathrm{ppm}$ cutoff for background uranium content. There are discrepancies, however, and when the analyses of samples collected in 1954 are arranged in sets (populations) according to tree species, some unusual distribution features appear (fig. 9). Calculations show that different geometric means exist for some of the populations. That the populations studied are typical for the kinds of trees in the area is indicated by the wide areal distribution of analyses. In order to determine whether or not the different means of the

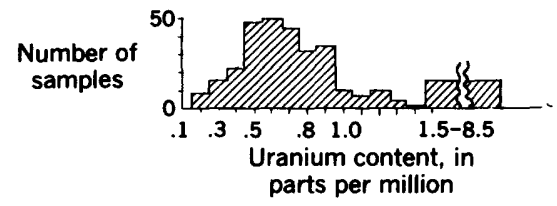

A. PONDEROSA PINE (295 SAMPLES)

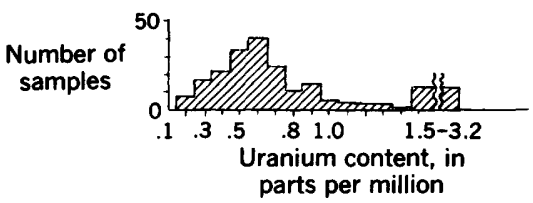

B. PINYON PINE (193 SAMPLES)

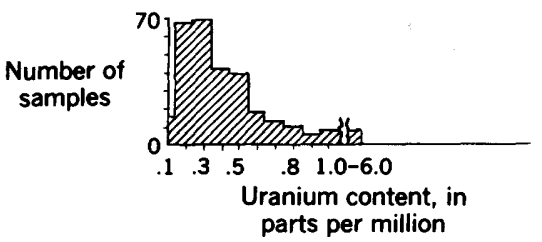

C. DOUGLASFIR (280 SAMPLES)

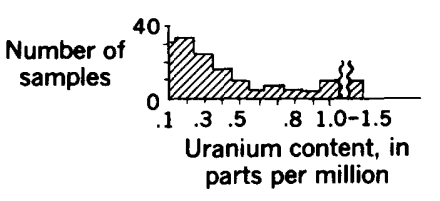

D. WHITE FIR (134 SAMPLES)

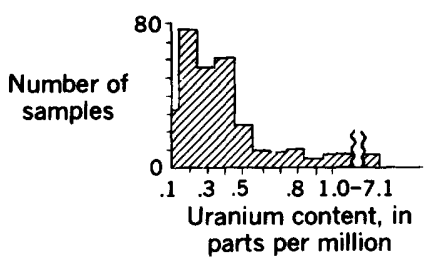

E. JUNIPER

(287 SAMPLES)

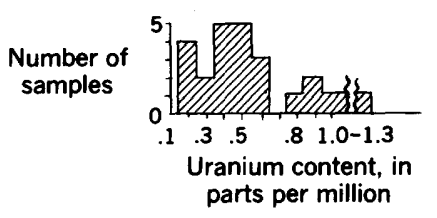

$F$. GAMBEL OAK (23 SAMPLES)

Figure 9.-Frequency distribution of plant samples arranged both py kind of plant and arithmetically by uranium content, South Elk Ridge, San Juan County, Utah. 
TABLE 2.- F and $t$ values calculated for pairs of tree populations, South Elk Ridge, San Juan County, Utah

\begin{tabular}{|c|c|c|c|c|c|c|c|}
\hline \multirow{3}{*}{ Compared trees ${ }^{1}$} & \multirow{3}{*}{$\begin{array}{l}\text { Number of } \\
\text { samples in } \\
\text { each tree } \\
\text { population }\end{array}$} & \multicolumn{3}{|c|}{$F$ values $^{2}$} & \multicolumn{3}{|c|}{$t$ values $^{3}$} \\
\hline & & \multicolumn{2}{|c|}{ Critical limits } & \multirow[b]{2}{*}{ Calculated } & \multicolumn{2}{|c|}{ Critical limits } & \multirow[b]{2}{*}{ Calculated } \\
\hline & & 0.05 & 0.01 & & 0.05 & 0.01 & \\
\hline $\begin{array}{l}\text { Rocky Mountain ponderosa pine* vs. white fir } \\
\text { Rocky Mountain ponderosa pine* vs. Douglas fir } \\
\text { Douglas fir* vs. white fir } \\
\text { Rocky Mountain ponderosa pine* vs. juniper } \\
\text { locky Mountain ponderosa pine* vs. Colorado pinyon pine } \\
\text { Colorado pinyon pine* vs. juniper } \\
\text { Colorado pinyon pine* vs. white fir } \\
\text { Juniper vs. white fir } \\
\text { Juniper vs. Douglas fir* }\end{array}$ & $\begin{array}{l}295 \text { vs. } 134 \\
295 \text { vs. } 280 \\
280 \text { vs. } 134 \\
295 \text { vs. } 287 \\
295 \text { vs. } 193 \\
193 \text { vs. } 287 \\
193 \text { vs. } 134 \\
287 \text { vs. } 134 \\
287 \text { vs. } 280\end{array}$ & $\begin{array}{l}1.28 \\
1.22 \\
1.28 \\
1.22 \\
1.29 \\
1.26 \\
1.30 \\
1.28 \\
1.23\end{array}$ & $\begin{array}{l}1.42 \\
1.34 \\
1.43 \\
1.33 \\
1.44 \\
1.38 \\
1.45 \\
1.42 \\
1.34\end{array}$ & $\begin{array}{l}1.8 \\
1.5 \\
1.2 \\
1.5 \\
1.1 \\
1.36 \\
1.6 \\
1.18 \\
1.0\end{array}$ & \begin{tabular}{r|}
1.96 \\
1.96 \\
1.96 \\
1.96 \\
1.96
\end{tabular} & \begin{tabular}{r}
-2.57 \\
2.57 \\
2.57 \\
\hdashline 2.57 \\
2.57
\end{tabular} & $\begin{array}{r}0.4 \\
2.4 \\
13.4 \\
0.3 \\
2.6\end{array}$ \\
\hline
\end{tabular}

${ }^{1}$ The asterisks indicate the population with the greater geometric mean; at the 0.01 probability level than where compared with respective critical the juniper and white fir have the same geometric mean.

${ }^{2}$ The critical $F$ and $t$ limits are determined from tables commonly found in statistical treatises and provide the basis for comparing $F$ and $t$ values calculated from the tree populations. More significance may be attached to cal$F$ ana $t$ limits at the 0.05 probability level. Calculated values greater than the critical limits indicate significant differences.

${ }^{3}$ Application of the $t$ test is valid only where no significant difference culated $F$ and $t$ values where they are compared with respective $F$ and $t$ limits 
analyses had any practical significance in plant-analysis prospecting, the populations were studied by statistical and empirical field methods. Examination was confined to samples collected in 1954 to restrict as much as possible the effects on the data of such factors as the time of sampling, changes in collectors, and modifications of analytical procedure.

Conventional statistical measures were used because the populations have distributions that resemble the log normal type. Actual tests for log normality were not made. Data was treated mathematically as Shoemaker and others (1955) treated semiquantitative spectrographic analyses. Initially, the data was transformed into logarithmic form and then arranged by placement in a series of equal logarithmic classes. Next, conventional statistical methods were applied to obtain comparisons of the geometric means of the populations. Geometric means were compared because of the stability of this statistic (Shoemaker and others, 1955).

The $F$ and $t$ tests, applied to pairs of populations, indicate whether or not significant differences exist between the populations (table 2). The $F$ test is an application of the ratio of the variances of two populations and is used to determine equality of the variances. When the calculated ratio of two variances exceeds a critical limit (given in prepared tables in standard statistical treatises), a difference exists between the variances and, therefore, between the compared populations. The critical $F$ limit can be chosen for any desired confidence level, which denotes the degree of confidence in stating that the difference is not due to chance. Critical $F$ limits for the 1 and 5 percent confidence levels are shown for comparison in table 2 , but the 1-percent level is chosen as the significant one. Significance at the 1-percent level means that the difference in the variances of the two populations could occur by chance only once in a hundred times.

The measure $t$ (table 2) tests the equality of the means of two populations and is the ratio of the difference between the means to the standard deviation of this difference (Youdin, 1951, p. 25). To apply the $t$ test, it must be assumed initially that there is no difference between the populations; where the $F$ test indicates that a difference exists, the $t$ test cannot validly be applied. In table 2 calculated $t$ values are compared to critical $t$ limits at the 1 and 5 percent confidence levels just as $F$ values are compared. It is apparent from the table that at the 1 percent level differences are probably real for all the comparisons except those (a) between Douglasfir and white fir, (b) between Rocky Mountain ponderosa and Colorado pinyon pines, and (c) between juniper and white fir. The closeness of the calculated $t$ and critical $t$ at the 1 percent level for juniper and Douglasfir 
is considered to mean no real difference because the 2.6 figure for calculated $t$ could really be 2.57 , depending on the significant figures used in the calculations. Also, field observation supports the viewpoint of no significant difference. A consideration of which population in each compared pair has the greater geometric mean (footnote 1 , table 2) permits the observation that the uranium contents of juniper, Douglasfir, and white fir are small compared to the uranium contents of pinyon and ponderosa pines.

Statistical treatment of uranium-in-plant analyses from South Elk Ridge has permitted a precise evaluation of empirical observations and tends to modify slightly the choice by other workers of a $1.0 \mathrm{ppm}$ cutoff to separate background and anomalous uranium contents of tree samples collected in widely separated areas on the Colorado Plateau (Cannon, 1954, p. 218; Froelich and Kleinhampl, 1960, p. 59; and P. F. Narten, written communication 1955). For different plant populations, the significant differences in uranium contents found by $F$ and $t$ tests could be due to a bias in analysis or to something inherent in the tree species that would affect the uranium content of branch-tip samples, such as different rates of uranium absorption or different uranium tolerance levels. There is no conclusive data to support any of the reasons for the differences, but successful prospecting is possible without such knowledge.

It is interesting to note (tables 2 and 3 ), however, that the average ash content of the tree species of each population appears to be related in some way to the findings of the $F$ and $t$ tests and to be inversely related to the background uranium contents of different tree species. Studies have shown that Colorado pinyon and Rocky Mountain ponderosa pines are likely to have a greater range in background amounts of uranium; anomalous contents for these trees begins at a higher level than for juniper, white fir, and Douglas fir. The number of samples from the other kinds of plants appeared too few to obtain any significant results by similar statistical treatment; however, Gambel oak was sampled in a quantity sufficient to permit some empirical observations concerning its uranium content. A study of the frequency distribution of analyses of 23 samples of oak leaves, each sample from a different tree (fig. 10), indicates that a background uranium content for oak ranges from 0.1 to about $0.6 \mathrm{ppm}$ uranium. Verification, however, requires many more samples. Ash content determined for 13 of the samples averaged 5.2 percent. In comparison with the ash and respective background uranium contents of the evergreens sampled (table 3), the upper limit of $0.6 \mathrm{ppm}$ for background uranium content in scrub oak seems to be reasonable. 


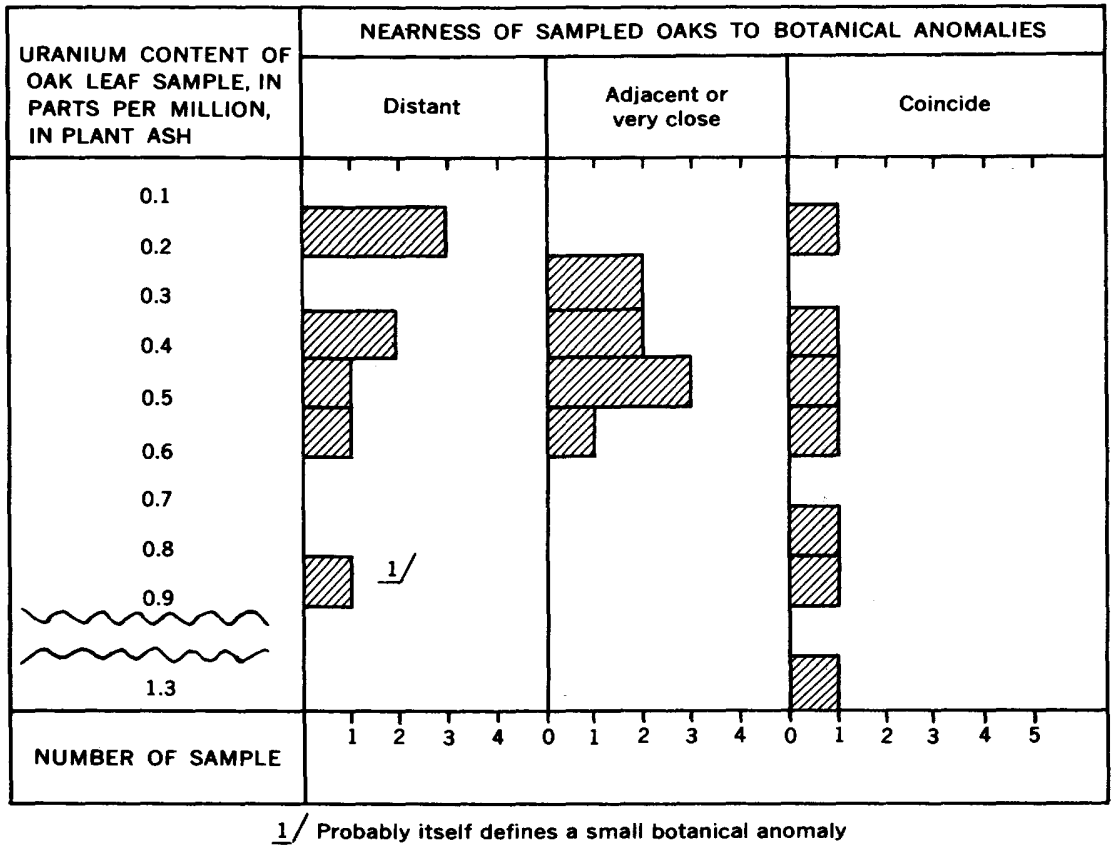

Figure 10.-Frequency distribution of sampled oaks arranged both by uranium content of the sample and by nearness to botanical anomalies which are defined by juniper,Colorado pinyon pine, Rocky Mountain ponderosa pine, and Douglasfir samples, South Elk Ridge, San Juan County, Utah.

Carl Koteff (oral communication, 1956) reports that the inverse relation of uranium and ash content also appears to exist in the evergreen and aspen genera in the Meeker, Colo., area. It appears, then, that throughout the Colorado Plateau, most kinds of evergreen trees and possibly scrub oak and aspen probably exhibit this relation. Caution must be exercised in exercised in extending the relation to other plants. H. L. Cannon (oral communication, 1956) says that such a relation does not exist between juniper and saltbush (Atriplex confertifolia), which has an average ash content of 20-30 percent.

It is useful in evaluating plant-prospecting results to know that samples from some tree species in the same environment characteristically contain different amounts of uranium, particularly if the expected magnitude of the differences can be determined for those plant samples that contain uranium in quantities near the cutoff limit between background and anomalous amounts. The expected magnitude of differences was obtained by studying field relations and frequency distributions for each population. Table 3 shows uranium contents expected to be exceeded by 10 and 30 percent of the total of each population. These uranium contents do not coincide with the 
TABLE 3.- Significant uranium and average ash content in plants and results of frequency distribution studies of different plant

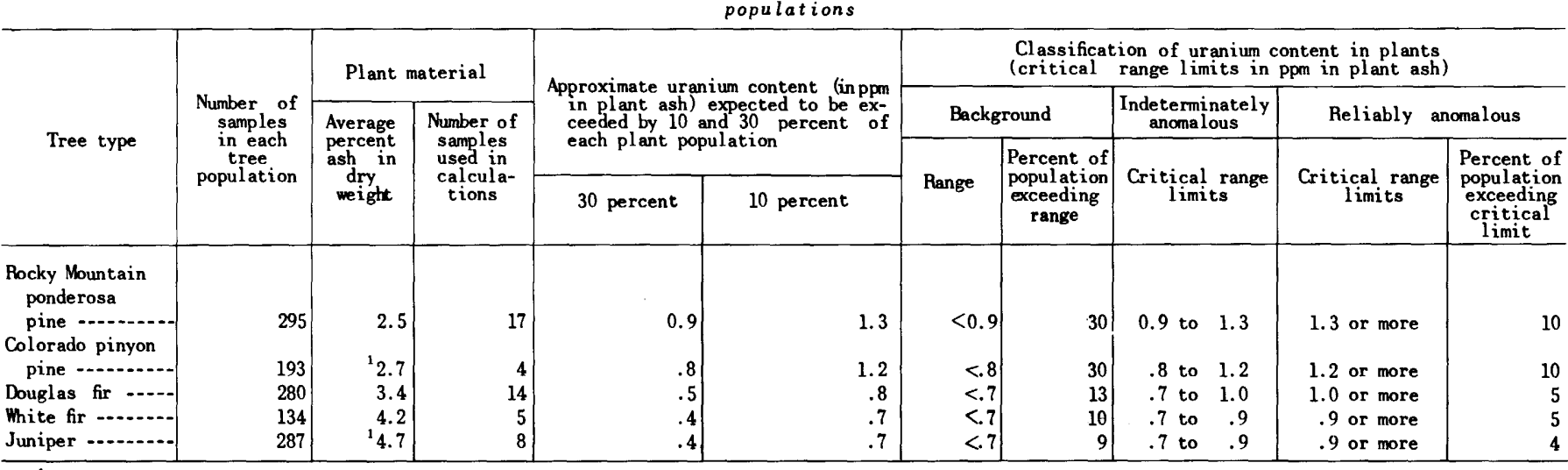

${ }^{1}$ Figures are in accord with those given for the Grants, N. Mex., district by Perry F. Narten (written communication, 1955), where pinyon branches from 941 trees contained an average of 2.3 percent ash and juniper branches from 667 trees contained an average of 5.6 percent ash. 
ranges for background uranium content that are based on empirically observed relations of samples to mineralized ground. Contents that coincide best with the empirically observed ranges are given in table 3 , along with the approximate percentages of each population that exceed the contents. From data in tables 2 and 3 and from empirical observations, the different populations show a crude progressive change in distribution of uranium from Rocky Mountain ponderosa pine to Colorado pinyon pine, to Douglasfir, and to white fir and juniper.

Some uranium-in-plant relations found to be especially useful in plant-analysis prospecting at South Elk Ridge appear in the classification section of table 3 . The ranges in uranium content for each category represent generalizations that only rarely needed minor changes to make better evaluations. The inclusion of one category requires an explanation: Some uranium contents in each population cannot be classified definitely as either background or reliably anomalous amounts $;{ }^{2}$ the contents within this range are classified as indeterminately anomalous. The necessity for classifying uranium content as indeterminately anomalous arises from sampling and analytical errors, both of which may be reduced but not completely eliminated by refinement of techniques and careful sampling and analysis. For Colorado pinyon pine and juniper the U.S. Geological Survey laboratory has been reporting analytical results with a standard deviation equal to 0.092 plus 0.066 times the concentration (expressed in parts per million of uranium), for a range from 0.4 to $40 \mathrm{ppm}$. Similar results are expected for the other kinds of trees that were sampled (L. B. Riley, written communication, 1956).

The differences in critical range limits for uranium contents appear in most cases to be very small from one kind of tree to another (table 3), especially when the known laboratory error is considered. Therefore, is it valid or even necessary to use slightly modified limits rather than a universal cutoff of about $1.0 \mathrm{ppm}$ ? Justification for using adjusted cutoffs is based on the following reasoning: doubt as to the presence of even small differences in limits decreases with an increase in the number of samples with such differences. Sampling and analytical errors could bias one analytical result more readily than a series; consequently, at South Elk Ridge more than one such sample generally marks a mineralized locality. Also, the use of a universal cutoff does not permit adjustment of cutoffs where contrast between background and anomalous contents is great or where the background level of uranium in tree samples is very low; whereas field observations

2 As used in this paper, "anomalous" uranium content in trees means "anomalously large amount" of uranium in plant ash, and all analyses are reported in parts per million (ppm) in plant ash. 
indicate that the lower limit of reliably anomalous uranium contents should be decreased. How these factors affect the definition of botanical anomalies is illustrated in table 4, where all the examples are from field data.

In table 4 (subarea 4 , anomaly 4 , tree 4 ), the use of a universal $1.0 \mathrm{ppm}$ cutoff permits saying that tree 4 might mark a small botanical anomaly. But, using the critical uranium limits of table 3 , it could be said that several trees, $3-5$, might mark a small botanical anomaly. Supplementing this with the fact that uranium contents of trees 3-5 contrast greatly with contents of adjacent trees, it can be said with much more certainty that these trees define an anomaly. Similar reasoning is applied to the other examples in table 4 .

\section{BOTANICAL ANOMALIES AT SOUTH ELK RIDGE-A PROSPECTOR'S GUIDE}

The tested parts of South Elk Ridge are described by subareas to facilitate discussion and reference (pl. 9 and fig. 5). Ratings of the reliability and favorableness for containing minable quantities of uranium of each botanical anomaly and reasons for the ratings appear in tables 10 and 11, and summaries of results of plant-analysis prospecting in each subarea are given. In general, those anomalies which are rated both as very reliable and as extremely favorable for containing uranium ore deposits should undergo the first testing by other exploratory methods.

To guide prospectors in locating anomalies, plate 9 shows their approximate location with respect to topography, and table 9 lists those trees marking the extremities of each anomaly, and the anomaly lengths or the approximate maximum extent of anomalies.

All the sampled plants are tagged and numbered in the field. Experience indicates that tags are torn off the plants before the numbers become illegible and that some tags remain on trees for 3 years or more. Collection of samples generally was done in consecutive order within each subarea; therefore, most sample numbers are consecutive. Thus, even though the numbers listed in table 9 may not be located in the field, anomalies may be found by locating numbers intermediate to those given in the table. A few anomalies in the field comprise adjacent series of samples and each series contains consecutively numbered samples. In the table, the limiting sample numbers for each such series are given.

\section{SUBAREA 1-S (SOUTH OF THE NOTCH)}

A total of about 5.5 linear miles of the Shinarump member of the Chinle formation or related units were tested in subarea 1-S (pl. 9)

$6224700-62-5$ 
TABLE 4.- Examples illustrating how the evaluation of botanical anomalies is altered by the consideration of adjusted cutoffs denoting an anomalous amount of uranium and the degree of contrast between uranium content of trees

\begin{tabular}{|c|c|c|c|c|c|c|c|c|c|}
\hline \multirow{2}{*}{\multicolumn{3}{|c|}{ Tree }} & \multicolumn{7}{|c|}{ Evaluation of botanical anomalies } \\
\hline & & & \multicolumn{3}{|c|}{$\begin{array}{c}\text { Before consideration of (a) cutoffs for each tree } \\
\text { and (b) contrast of uranium content in trees }\end{array}$} & \multicolumn{3}{|c|}{$\begin{array}{l}\text { After (a) consideration of contrast of uranium } \\
\text { content in trees, and (b) adjusting the cut- } \\
\text { off for each tree depending on its type }\end{array}$} & \multirow{2}{*}{$\begin{array}{l}\text { Degree of contrast } \\
\text { in uranium } \\
\text { content between } \\
\text { trees at and } \\
\text { adjacent to } \\
\text { anomalies }\end{array}$} \\
\hline No. & Type $^{1}$ & $\begin{array}{c}\text { Uranium } \\
\text { content } \\
(\mathrm{ppm})\end{array}$ & $\begin{array}{c}\text { Trees marking } \\
\text { botanical } \\
\text { anomaly }\end{array}$ & $\begin{array}{l}\text { Classification } \\
\text { of tree } \\
\text { uranium } \\
\text { content }\end{array}$ & $\begin{array}{l}\text { Classification } \\
\text { of reliability } \\
\text { of botanical } \\
\text { anomaly }\end{array}$ & $\begin{array}{c}\text { Trees marking } \\
\text { botanical } \\
\text { anomaly }\end{array}$ & $\begin{array}{l}\text { Classification } \\
\text { of tree } \\
\text { uranium } \\
\text { content }\end{array}$ & $\begin{array}{l}\text { Classification } \\
\text { of reliability } \\
\text { of botanical } \\
\text { anomaly }\end{array}$ & \\
\hline \multicolumn{10}{|c|}{ Subarea $1 S$, anomaly 19} \\
\hline $\begin{array}{r}1 \\
2 \\
3 \\
4 \\
5 \\
6 \\
7 \\
8 \\
9 \\
10\end{array}$ & $\begin{array}{l}\text { Douglas fir } \\
\begin{array}{l}\text { Ponderosa pine } \\
\text { Douglas fir }\end{array} \\
\begin{array}{l}\text { White fir } \\
\text { Ponderosa pine }\end{array}\end{array}$ & $\begin{array}{r}0.4 \\
.2 \\
.9 \\
.7 \\
.8 \\
.6 \\
.8 \\
.4 \\
.2 \\
.5\end{array}$ & $\begin{array}{l}3 \\
4\end{array}$ & 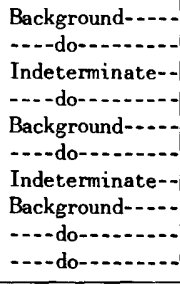 & $\begin{array}{l}\text { Indetermi- } \\
\text { nate. }\end{array}$ & $\begin{array}{l}3 \\
4 \\
5 \\
6 \\
7\end{array}$ & 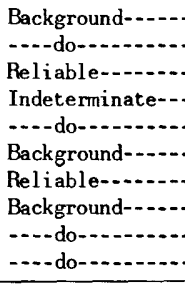 & $\left\{\begin{array}{l}\text { Indetermi- } \\
\text { nate, } \\
\text { perhaps } \\
\text { reliable. }\end{array}\right.$ & $\begin{array}{l}\text { Moderate(?) at } \\
\text { both ends of the } \\
\text { anomaly. }\end{array}$ \\
\hline \multicolumn{10}{|c|}{ Subarea 4, anomaly 4} \\
\hline $\begin{array}{l}1 \\
2 \\
3 \\
4 \\
5 \\
6 \\
7 \\
8\end{array}$ & $\begin{array}{l}\text { Pinyon pine } \\
\text { Ponderosa pine } \\
\text { Douglas fir } \\
\text { Juniper } \\
\text { Pinyon pine } \\
\text { Ponderosa pine }\end{array}$ & $\begin{array}{r}0.3 \\
.6 \\
.9 \\
1.0 \\
.7 \\
.4 \\
.4 \\
.5\end{array}$ & $\begin{array}{l}3 \\
4 \\
5\end{array}$ & 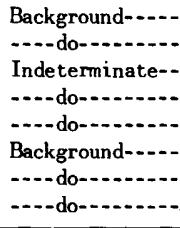 & $\begin{array}{l}\text { Indetermi- } \\
\text { nate. }\end{array}$ & $\begin{array}{l}3 \\
4 \\
5\end{array}$ & 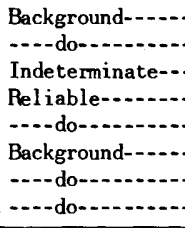 & $\left\{\begin{array}{l}\text { Indetermi- } \\
\text { nate, } \\
\text { perhaps } \\
\text { reliable. }\end{array}\right.$ & $\begin{array}{l}\text { Great (trees } 1-3 \text { ) } \\
\text { to moderate } \\
\text { (trees 5-8). }\end{array}$ \\
\hline \multicolumn{10}{|c|}{ Subarea 7, anomaly 2} \\
\hline $\begin{array}{l}1 \\
2 \\
3\end{array}$ & $\mid \begin{array}{c}\text { Juniper } \\
-10-10\end{array}$ & $\begin{array}{r}0.5 \\
.5 \\
.4\end{array}$ & & 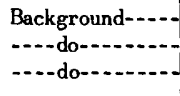 & & & 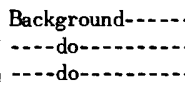 & & $\begin{array}{l}\text { Small (trees } 1-5) \\
\text { to great (trees } \\
9-13)\end{array}$ \\
\hline
\end{tabular}




\begin{tabular}{|c|c|c|c|c|c|c|c|c|}
\hline $\begin{array}{r}4 \\
5 \\
6 \\
7 \\
8 \\
9 \\
10 \\
11 \\
12 \\
13\end{array}$ & 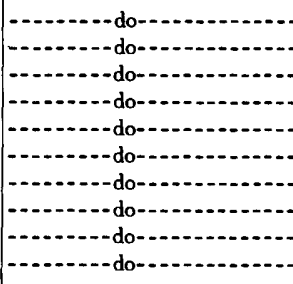 & $\begin{array}{r}.7 \\
.9 \\
.5 \\
1.0 \\
.9 \\
1.0 \\
.3 \\
.5 \\
.4 \\
.2\end{array}$ & $\begin{array}{l}5 \\
6 \\
7 \\
8 \\
9\end{array}$ & 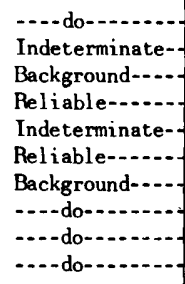 & $\begin{array}{l}\text { Indetermi - } \\
\text { nate, } \\
\text { perhaps } \\
\text { reliable. }\end{array}$ & $\begin{array}{l}4 \\
5 \\
6 \\
7 \\
8 \\
9\end{array}$ & 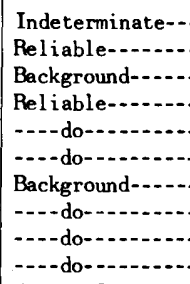 & $\begin{array}{l}\text { Indetermi- } \\
\text { nate, } \\
\text { perhaps } \\
\text { reliable. }\end{array}$ \\
\hline
\end{tabular}

${ }^{1}$ Trees are arranged consecutively as they appear in a line of samples in the field. 
by plant-analysis prospecting in 1953 and 1954. In 1953, A. J. Froelich and W. R. Martin collected 101 samples along the segment between anomalies 4 and 9 (pl. 9). In 1954, testing was continued by collecting about 500 samples along the segment that adjoins the area sampled in 1953. Fifty were repeat samples in the vicinity of some anomalies to check reliability classification of the anomalies.

The tested horizon lies about 120 to 160 feet beneath the plateau top on north-, east-, and west-facing slopes. Botanical anomalies $1-10,16$, and 17 are easily accessible in part by roads which go to drill and rim-strip sites at the base of the Chinle and in part by the main road connecting South and North Elk Ridge. No roads go to the other anomalies.

Eight types of trees were sampled, the distribution of types being chiefly dependent on slope-facing directions which affect the amount of insolation received on the slopes (see section "Plant ecology"). At anomaly 2 ( $\mathrm{pl} .9$ ), though, water availability controlled by geology influences the kinds and distribution of trees. Here a stand of ponderosa pine grows on a shale and mudstone slope above sandstone in the basal part of the Chinle. Near the base of the sandstone, ponderosa pine is mixed with Douglasfir and white fir. The change is attributed to increased amounts of moisture available in the sandstone, which probably contains a perched water table, and to the shade provided by the steepened slope at the sandstone. Both the Douglasfir and white fir require more moisture and probably more shade for growth than the ponderosa pine (Weaver and Clements, 1938, p. 405-410, 506; and Gail, 1921, p. 288). Rocky Mountain maple, a tree requiring much moisture, grows in dense thickets near the base of the sandstone at anomaly 2 , substantiating the explanation of lithologic control of moisture.

\section{GENERAL GEOLOGY}

Large segments of the sample horizon are covered by colluvium, which probably ranges in thickness from a few feet on most slopes to many feet at the heads of the big reentrants near anomalies 10 and 18-20. That the colluvium is thickest at the heads of these reentrants is indicated by the relatively gentle slopes, the dearth of outcrops, and the absence of a bench within the upper 40 feet of the Moenkopi formation, which is present along most other parts of the subarea.

Sandstone at the base of the Chinle crops out at more than half of the botanical anomalies. In general, the sandstone is blocky or massive and cross-stratified. It grades upwards and laterally chiefly into alternating more thinly stratified siltstone and sandstone. The siltstone is light grayish white and, where hematitic, mottled purple and 
white, sandy, well cemented, very thin bedded, and generally intensely and minutely fractured. The thinner bedded sandstone is silty to medium and even coarse grained, and generally well cemented. Interstratified shale and mudstone lenses are uncommon in the massive sandstones. No sulfides were noted at exposures, but pyrite was abundant locally in some drill core at anomalies 2 and 17 and secondary copper carbonates were seen at the contact of the Moenkopi and Chinle where stripping has exposed it north of anomaly 10. Coaly material (and bitumen?) occur abundantly at only a few anomalies.

Massive sandstone is absent south of anomaly 1 and variegated graypurple claystone of the Monitor Butte member of the Chinle formation is the dominant unit overlying the Moenkopi. From anomaly 1 north to anomaly 2 the test horizon is mostly covered; massive sandstone is absent at many places and, where present, is as much as 25 feet thick. There are few outcrops north of anomaly 2 to beyond anomaly 3 and massive sandstone is inferred to be absent or less than 10 feet thick. From about anomalies 4 through 7 , removal of overburden has exposed many anomalously radioactive thick lenticular sandstones. A few outcrops between anomalies 7 and 10 indicate that massive sandstone is present throughout much of this segment. Here the sandstone is inferred to range in thickness from about 8 to 20 feet. The slope is covered between anomalies 10 and 11 . From anomalies 11 to 15 massive sandstone is inferred to be generally less than 10 feet thick, except at anomalies 12 and 14 where it resembles a channel-fill unit because of its abruptly increased thickness. Along this segment the sandstone grades upward into very thin bedded white and mottled purple and white sandy siltstone, upon which is developed a well-defined bench about 25 feet above the sandstone. The few outcrops from anomalies 15 to 17 indicate that some massive lenticular sandstone is present and may fill shallow and narrow channels. The slope is covered between anomalies 17 and 20.

\section{RESULTS OF PHYSICAL EXPLORATION AT BOTANICAL ANOMALIES}

Drilling at botanical anomaly 2, done for the U.S. Geological Survey by Mott Core Drilling Co., shows that massive sandstone at the test horizon ranges in thickness from a few feet to about 25 feet. The drill holes cut some uranium mineralized sandstone and mudstone at different horizons within the lowest 35 feet of the Chinle formation. U.S. Atomic Energy Commission drilling (Eugene W. Oertell, written communication, 1956) at botanical anomalies 4-6, has defined an arcuate Shinarump-filled channel, and ore deposits are known just east of anomaly 6. 
Removal of overburden at the east end of anomaly 7 has exposed the uppermost part of the Moenkopi formation and an overlying 10foot-thick lens of sandstone that contains local disseminations of coaly material (or bitumen?). Locally both the sandstone and the upper part of the Moenkopi are anomalously radioactive.

Drilling for the T.S. Geological Survey by Mott Core Drilling Co. at the southern end of botanical anomaly 16 and at anomaly 17 found relatively thick sandstone and some weakly uraniferous rock at the base of the Chinle formation.

\section{RESUlTS AND CONOLUSIONS OF BOTANTCAL PROSPECTING}

Twenty botanical anomalies occur along about 5.5 miles of ore horizon tested by botanical prospecting. Nearly all of the anomalies are reliable (table 10A). Based on geologic criteria, which was determined partly by drilling, the anomalies most likely to contain ore deposits (table 11A) are 5, 6, 8, 9, 10, 12, 14, and parts of 7, 16, and 17 .

The botanical anomalies range in length from 50 to about 2,000 feet; most have lengths of about 100 to 500 feet (table 9). Based on the total maxinum lengths, reliable botanical anomalies comprise about 27 percent ( 7,700 feet) of the total length of sampled horizon. Anomalies rated favorable for containing ore deposits constitute about 10 percent (3,000 feet) of the sampled horizon and about 20 percent of that part of the horizon known or inferred to be underlain by sandstone 10 feet or more thick. Anomalies rated indeterminately favorable for containing ore deposits constitute about 15 percent $(2,240$ feet) of the horizon known or inferred to be underlain by sandstone 10 feet or more thick. In general, most of the botanical anomalies found are where sandstone is known or inferred to be present at the base of the Chinle.

\section{SUBAREA 1-N (NORTH OF THE NOTCH)}

Prospecting north of the Notch tested 2.5 linear miles of rock at the ore horizon. A. J. Froelich and W. R. Martin collected 207 branch-tip samples in 1953, using a sample interval ranging from 50 to 100 feet. Twenty-six additional samples were taken in the areas of greatest exploration activity. The tested horizon lies along east-, west-, and south-facing slopes (pl. 9). An open forest dominated by ponderosa pine covers a large proportion of the main westfacing slope at the sample horizon. Here undergrowth is scant to dense, and at a few places patches of pinyon-juniper forest extend up into the ponderosa forest. The sample horizon on the south-facing slopes is within the pinyon-juniper zone. The main east-facing slope is covered chiefly by a dense stand of firs for large distances above 
and below the sample horizon. Undergrowth is not as dense on this slope because the trees shade the forest floor.

The wild onion Allium sp., a sulfur indicator (Cannon, 1954, p. 218), and some Lathyrus sp., a legume resembling in appearance the primary selenium indicators of the Astragalus species, grow in a large patch on the bench developed on the upper part of the Moss Back member of the Chinle formation. The patch lies near the crest of a small gentle anticline, in a slight swampy depression, at an altitude of about 8,740 feet (see pl. 9, botanical anomaly 33, in the unsurveyed NE $1 / 4$ sec. 36 , T. 34 S., R. 19 E. The relation of these plants to uranium deposits is not clear, but the patch coincides poorly with a botanical anomaly (33, pl. 9) found by analyzing tree samples (fig. 11).

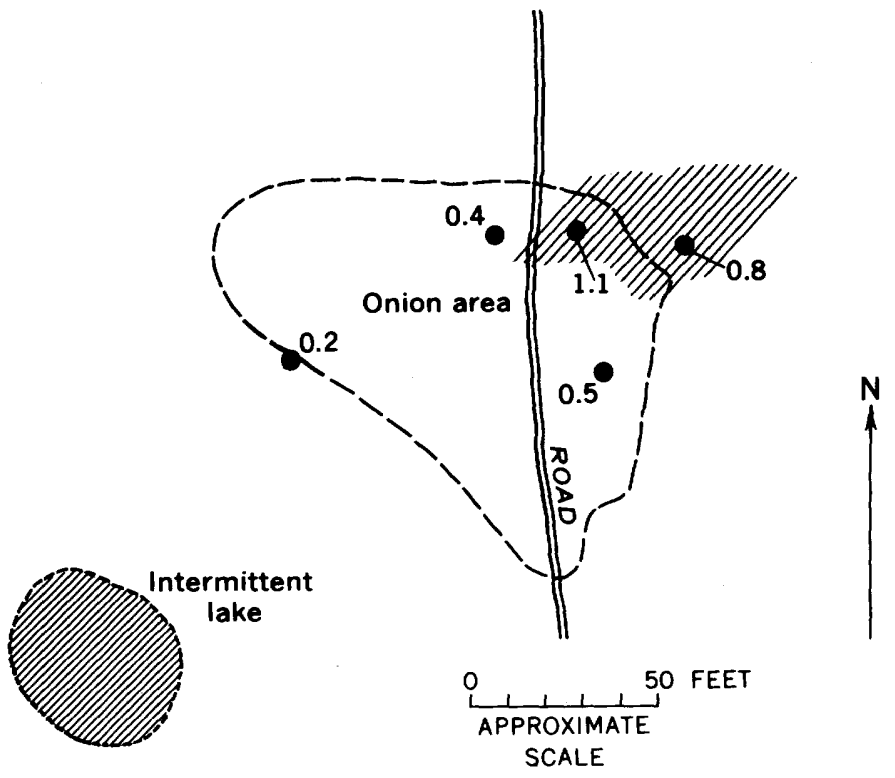

EXPLANATION

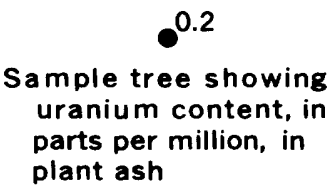

Botanical anomaly 33

parts per million, in

plant ash

Figure 11. - Sketch map showing relation of distribution of onion plants to botanical anomaly 33, subarea 1-N, Elk Ridge, San Juan County, Utah.

There is no close obviously localized source of sulfur to account for the presence of the onions, but minute amounts of sulfur from the adjacent rock surface may have been concentrated by drainage of 
surface water inte the depression. No explanation is offered for the anomaly delimited by trees that contain anomalous amounts of uranium.

\section{GENERAL GEOLOGY}

Colluvium and humic material cover most of the tested horizon, but because slopes are generally very steep, the cover is thought to be thin, ranging in thickness from about 1 to 15 feet. This estimate is based on observations made at and adjacent to outcrops. Even where the contact of the Moenkopi and Chinle formations is covered, the upper part of the Shinarump member of the Chinle formation or related sandstone generally crops out, and estimates of the continuity of sandstones at the base of the Chinle are probably accurate, particularly on the east-facing slope. Stripping along parts of the ore zone has aided geologic interpretations.

In subarea $1-\mathrm{N}$ the geologically determined extent of potential host rock of the basal Chinle formation constitutes what appears to be an abnormally large proportion of the tested ground when compared with all of the Elk Ridge area. Basal sandstones of the Chinle seem to be thickest and most continuous along the western one-third of the slope segment which extends from the west limit of sampling to botanical anomaly 22. Near the spring (pl. 9) stripping and drilling (U.S. Atomic Energy Commission, written communication, 1953) showed massive sandstones ranging in thickness from about 30 to 60 feet, but drilling located no ore deposits. At outcrops, the sandstones consist chiefly of fine- to medium-grained quartz and contain sparse to abundant interstitial silt and a few gray to purple siltstone and mudstone lenses. Most of these lenses are less than 3 feet thick, but some are as much as 10 feet thick. Much of the slope is covered between botanical anomalies 23 and 25 , but stripped parts indicate that thick sandstone is very discontinuous. Lenses of massive cross-stratified sandstone and siltstone locally overlap, and in places they occur within sequences of more thinly stratified sandstone and siltstone.

Ore deposits may be present at anomaly 25 because much mineralized rock is associated with a channel-fill unit that is more than 20 feet thick. The most radioactive rock at the outcrop is a carbonaceous gray siltstone lens at the northeast bank and near the bottom of the channel. Locally some of the siltstone is of ore grade by radioactivity measurement, and a sample of the most radioactive part found contained 0.31 percent $\mathrm{e} U$ and 0.22 percent $\mathrm{U}$ (table 1 ).

Between botanical anomalies 25 and 26 the lowest 10 feet of the Chinle consists mainly of regular thinly interstratified reddish-purple and white siltstone and sandstone. Some weathered sandstone is light 
brown to yellowish, showing much irregular limonite staining. From anomalies 26 through 32 sandstones are relatively continuous along the base of the Chinle. The sandstones range in thickness from 8 to about 50 feet and are lenticular. At least some of the lenses, particularly the thick ones, appear to be asymmetric channel-fillings where the steep side represents the relic cut-bank slopes of a channel. The lenses generally consist of massive cross-stratified fine- to coarsegrained sandstone and locally contain many small lenses of reddishpurple to white and gray siltstone. Carbon as coaly matter is abundant locally in the lenses. At some places north from botanical anomalies 25 to 32 an upper massive sandstone directly overlies a lower massive sandstone or locally is separated from the lower sandstone by only a few feet of thin-bedded sandy siltstone. Mining has been confined to the lower sandstone.

\section{RESULTS OF PHYSICAL EXPLORATION AT BOTANICAL ANOMALTES}

Subarea $1-\mathrm{N}$ was tested by drill holes made under the auspices of the U.S. Atomic Energy Commission. Their data (written communication, 1953) comprise all of the following drill-hole information.

At botanical anomaly 23, three drill holes cut only minor amounts of uranium and some pyrite and copper sulfides. Two drill holes a few hundred feet north of anomaly 24 showed anomalous radioactivity but no ore at the contact of the Moenkopi and Chinle formations. Drill holes behind the outcrop at anomaly 25 showed intensely radioactive zones, and core contained copper and iron sulfides and bitumen at the contact of the Moenkopi and Chinle formations. A 140-footlong adit failed to find ore (Richard Q. Lewis, Sr., written communication, 1956). A bulldozer road from anomalies 24 to 30 has exposed, except for short distances, the contact of the Moenkopi and Chinle formations. Good channel-fill structures and locally intense radioactivity occur at or near anomalies 28,29 , and 30 . An unexamined adit adjacent to anomaly 30 penetrates the basal part of a Shinarumpfilled channel. Bulldozer cuts have exposed the contact of the Moenkopi and Chinle formations throughout much of botanical anomaly 32 , and a number of short adits penetrate the basal parts of thick sandstones of the Shinarump member of the Chinle formation. Radioactivity tests located many places with about twice background intensity along the contact of the Moenkopi and Chinle, and at 2 places intensity exceeded 10 times the background amount. Drilling north of anomaly 32 found radioactivity at the base of the Chinle that ranged from very slight to moderate in intensity. The moderately radioactive rock contained $0.02-0.05$ percent $\mathrm{U}_{3} \mathrm{O}_{8}$.

$6224700-62-6$ 


\section{RESULTS AND CONCLUSIONS OF BOTANICAL PROSPECTING}

Twelve botanical anomalies, all reliable (table 10B), occur along about 2.5 miles of ore horizon tested by botanical prospecting. Geologic criteria indicate that six botanical anomalies, $23,25,28,30,31$, and 32 , have the best chance of containing ore deposits (table $11 B$ ). Anomaly 33 indicates a uranium deposit, but no ore is expected because the few ore deposits known from the Moss Back in the area occur at the base of the unit, whereas it is believed that the trees with anamalous uranium are reflecting uranium from a shallower nonore source.

There is a good correlation between botanical anomalies and ground considered favorable on the basis of geology for containing ore deposits. There is good correlation between anomalous radioactivity at the sample horizon and botanical anomalies (table 10B).

The botanical anomalies range in lengths from 50 to 2,400 feet (table 9). Most, however, have a maximum length of less than 600 feet. Based on the lengths, anomalies comprise about 40 percent (1 mile) of the total length of sampled horizon. Reliable anomalies constitute all of this length. Anomalies rated favorable for containing ore deposits constitute about 30 percent of the sample horizon.

Sandstone may underlie about 70 to 90 percent of the length of tested horizon but a maximum of only about 80 percent of the sandstone is known or inferred to be 10 feet or more thick. Botanical anomalies indicate that probably 45 to 60 percent of the sandstone is mineralized and of that, geologic criteria indicate that 35 to 50 percent might contain ore. The large indicated percentages of mineralized and ore-bearing rock do not appear to be compatible with the facts about the known extent of mineralized ground on Elk Ridge, where a figure of about 10 percent or less more nearly approximates the real distribution of mineralized ground. An examination of the plantanalysis data used in making the calculations shows that the percentages obtained are large, at least in part, because the anomaly lengths are too great. The length of any one anomaly generally includes some barren parts because a few trees containing background uranium are generally interspersed with trees containing anomalous uranium

The presence of a contamination factor at some of the botanical anomalies also increases their length. That contamination is present, particularly in the tested segment from anomalies 25 to 32 , is indicated by extremely large anomalous uranium contents of some samples and the areal distribution of these samples. Of the 121 samples that test this segment, 7 percent contain uranium ranging in amount from 9.9 to $25.0 \mathrm{ppm}$. Such large amounts are generally attributed to con- 
tamination. Also, these 7 percent grow in the proximity of mines and prospects, active in 1953 , where contamination would most likely occur. Others of the 121 trees may be contaminated to a lesser degree. An additional 26 samples taken in 1953 from the most intensely prospected places (botanical anomalies 25 and 32 ) contained uranium ranging in amount from 1.0 to $18.0 \mathrm{ppm}$. These results also support the conclusion that some of the sampled trees had been contaminated by dust from prospecting and mining activity. A downward adjustment of the percentages indicated by plant analysis of mineralized ground to account for the contamination factor would yield a value that would be more compatible with the percentage of basal Chinle host rock determined by geologic criteria.

Based mainly on plant-sample data, the ground in subarea 1-N between the west limit of testing and anomaly 23 is unlikely to contain much mineralized rock. Geologic and plant-sample studies indicate that, for the area tested, ore deposits generally are most likely to occur in the area from botanical anomalies 25 to 32 , inclusive.

\section{SUBAREA 2 (RIGAIIA CANYON)}

The sampled part of subarea 2 lies along the steep west slope of Kigalia Canyon (pl. 9). Two linear miles of sample horizon was tested by collecting 134 branch-tip samples at sample intervals of 50 to 100 feet. Soil, colluvium, and vegetation cover much of the tested area. A 50-foot interval was used in covered areas where sandstone was inferred to be present in the lowest part of the Chinle, and a lengthened interval of 75 to 100 feet was used where the sandstone was judged to be absent.

The area may be reached by walking downslope from a network of logging roads made on the Moss Back member of the Chinle formation. Generally the sampled slopes face east and support a mixed stand of conifers. It was possible to confine sampling mostly to ponderosa pine; however, juniper and Douglasfir represent the tree types most sampled between botanical anomalies 2 and 3 and between anomalies 3 and 4, respectively. The different slope-facing directions on each side of the large reentrant here (pl. 9) apparently provide such different climatic conditions that at the sample horizon juniper comprises most of the tree growth on the southeast-facing slope and Douglasfir most of that on the north-facing slope.

A locality of anomalously intense radioactivity not defined by a botanical anomaly occurs about 500 feet east-southeast of botanical anomaly 3. Here, radioactivity of 4 times background intensity was measured in a small hole dug into colluvium near the base of a sandstone exposure. The radioactivity is moderately close to the nearest 
sampled tree, which is about 20 feet laterally from and 15 feet above the hole.

\section{GENERAL GEOLOGY}

Sandstone at the base of the Chinle crops out as small lenses along the sample horizon. In general, upper and lower contacts of the lenses are not exposed. Lenses average about 10 feet in inferred length along the sample horizon. The sandstone is grayish white and in some places light brown and is generally massive and crossstratified in its lower part and thin bedded in its upper part. Minor conglomeratic sandstone stringers and small to moderate amounts of intersititial silt and clay occur in the sandstone, which is generally poorly sorted and fine to coarse grained. The sandstone is absent from the base of the Chinle north of botanical anomaly 2 and is inferred to be about 5 to 15 feet thick between anomalies 3 and 4 . At many places, as between anomalies 7 and 8 , strata in the basal part of the Chinle consists of thinly interstratified mudstone, siltstone, and sandstone.

Drilling or stripping of cover had not been done in that part of the Kigalia Canyon subarea that was tested by botanical prospecting; consequently, a description of physical exploration at this place is omitted.

\section{RESULTS AND CONCLUSIONS OF BOTANICAL PROSPECTING}

Prospecting along the west slope of Kigalia Canyon located eight botanical anomalies, three of which are relatively reliable and coincide with localities determined to be geologically favorable for containing ore deposits (tables $10 C$ and $11 C$ ). Concurrent with the plant sampling, scintillometer testing indicated anomalously intense radioactivity at three localities; two approximately coincide with botanical anomalies 3 and 8 , and one is away from any botanical anomaly. The tested horizon north of botanical anomaly 3 and between anomalies 4 and 7 appears unlikely to contain ore deposits because of a lack of anomalies and favorable sandstone. However, the tested horizon from about anomaly 4 to about anomaly 6 does not correspond with the position of the contact of the Chinle and Moenkopi formations as mapped by R. Q. Lewis Sr., and R. H. Campbell (pl. 9). It may very well be that the trees sampled along this segment are below the ore horizon, and if this is so, any observations concerning uraniferous ground along this part of the tested horizon are of little value, as are anomalies 4 and 5 . Botanical anomaly 3 and the anomalously radioactive locality east-southeast of it appear to be the anomalies most likely marking ore deposits.

Some estimate of the amount of ground underlain by sandstone approximately 10 feet or more thick was made by examination of 
topography and exposures. Exposures of such sandstone constitute about 4 percent (400 feet) of 2.0 linear miles of tested and examined ground; the known and inferred extents constitute 20 to 40 percent of the total tested and examined ground. The remaining 60 to 80 percent is underlain by sandstone less than 10 feet thick or by interstratified claystone, shale, siltstone, and thin sandstone of the Chinle formation.

Botanical anomalies comprise about 10 percent $(1,080$ feet) of the examined sample horizon's linear length (table 9). Only three anomalies, 3, 7, 8, constituting about 40 to 50 percent of the 1,080 feet, appear to coincide with potential ore-bearing rock (table $11 C$ ).

\section{SUBAREA 3 (PEAVINE CANYON)}

Twenty samples were collected along about 2,000 linear feet of strata at the bottom of the Chinle formation in Peavine Canyon. Nearly all the sampled trees were junipers; three were pines. At the north end of the tested area sandstone has been exposed at a stripping; further north the slope is extensively covered by colluvium and dense forest. Accessibility to the sample horizon is easy via the road to the stripping.

\section{GENERAL GEOLOGY}

Massive sandstone crops out for about 1,400 feet southward from the stripping, but the base of the sandstone is not well exposed. For about 1,000 feet southward from the stripping the sandstone has an inferred thickness of about 25 feet. Further south, it is progressively thinner, and is absent from the southernmost tested ground.

The sandstone generally grades upwards into more thinly stratified and more thinly split siltstone and sandstone. Some of the thickness of the massive sandstone is probably attributable to lateral gradation of overlying units into the sandstone, and some of the thickening probably represents channel-type filling in the top of the Moenkopi. Characteristically, the massive rock is a white cross-stratified and generally fine- to medium-grained quartz sandstone. At some places the upper part is thin bedded and more silty than the lower part; at some places the basal 10 to 12 feet is a medium- to coarse-grained conglomeratic sandstone. Some conglomeratic sandstone lenses, mostly less than 1 foot thick, are present throughout the unit where it crops out near the stripping. The massive sandstone has split into units that range in thickness from about 5 to 10 feet; some of the units are in direct contact, and others are separated by silty sandstone about 1 to 2 feet thick. 


\section{RESULTS OF PHYSICAL GXPLORATION AT BOTANICAL ANOMALIES}

Radioactivity of background intensity was measured along the sandstone and along the inferred contact of the Moenkopi and Chinle except at the stripping, where a maximum reading of about 90 times background was recorded in the top 3 inches of the Moenkopi and about 25 times background was recorded in the lowest foot of the Chinle in sandstone. The most radioactive rock of the Moenkopi is a micaceous sandstone in the upper part of a light-gray-green zone that is 1.5 feet thick. Secondary copper minerals coat fractures and bedding planes of the most radioactive part of the Moenkopi, and the fractures also appear to be coated with very fine particles of carbon. The most radioactive sandstone of the Chinle is poorly sorted, coarse grained and conglomeratic, with the latter part containing light-graygreen mudstone fragments of the Moenkopi and carbonaceous material as grain coatings.

\section{RESUlts AND CONClusions of botanical PROSPECTING}

Plant analysis and radiometric tests indicate that the sandstone south of the stripping is not mineralized. Only two nonadjoining sampled trees near the stripping contain amounts of uranium slightly greater than those amounts in nearby samples, but the two trees are Colorado pinyon pines, and do not contain enough uranium to constitute botanical anomalies. The sandstone may not be a favorable host for uranium because of an apparent absence of mudstone strata. Any more tests, if contemplated, should be drill tests to the east and north of the stripping that exposes some mineralized rock.

More botanical prospecting is warranted at the head of Peavine Canyon, including that part outside the subarea discussed, because the slopes are generally covered and some sandstone, probably representing channel-fill units in part, appears to be present at the base of the Chinle and because the area lies near ore deposits at the heads of Burch and Cherry Canyons.

\section{SUBAREA 4 (CHERRY CANYON)}

The prospected part of subarea 4 is a segment about 3 miles long that required 266 samples for adequate testing.

At the sample horizon on the long east-facing slope of the canyon, juniper and Colorado pinyon and Rocky Mountain ponderosa pines dominate an open forest; along the north-facing slope of the canyon, Douglasfir and white fir dominate a much denser forest. All of these types of trees were sampled.

Roads to mining and exploratory stripping sites provide easy access by vehicle to the east half of the tested horizon; the west part can be reached only by walking. 


\section{GENERAL GEOLOGY}

There are few outcrops of basal rocks of the Chinle in the tested part of Cherry Canyon because of abundant colluvium and forest cover. Even where the rocks crop out, their contact with the underlying Moenkopi formation is generally covered. Sandstone at the base of the Chinle is discontinuous; lenses range in inferred length from a few score to several hundred feet and range in maximum thickness from about 1 to 20 feet. Most lenses range in maximum thickness from 6 to 15 feet; a few lenses are superposed and have inferred maximum combined thickness of about 20-40 feet. Fresh exposures are generally white to gray, but weathered surfaces are white to buff or brown. Between anomalies 7 and 8 the sandstone is locally dull black for a few inches above its contact with the Moenkopi, and brown above this. In the Cherry and Woodenshoe Canyon areas, bitumen impregnates some of the sandstone; black material staining some of the sandstone may be a residual bitumen product. The sandstone is generally medium to coarse grained and contains sparse to abundant interstitial silt or clay. Thin mudstone lenses are present locally in the sandstone but are less common than conglomeratic sandstone lenses and stringers. Much of the sandstone is massive and cross-stratified in its lower and middle parts and more thinly split and finer grained in its upper part where it intertongues with and grades into evenly and thinly stratified white to mottled reddish-purple and white sandy siltstone. A light grayish-green zone, having a maximum thickness of a few inches, commonly occurs in the uppermost part of the Moenkopi formation just beneath the massive sandstone of the Chinle.

Massive sandstone appears to be absent from the northwest limit of the tested ground to about botanical anomaly 1 (pl.9). In this sector, mudstone and very thin lenticular sandstone of the Chinle formation overlie the Moenkopi. From anomalies 1 to 3 sandstone slump blocks of Shinarump-like rock, nearly in place, jut out of colluvium. Shinarump-like rubble, consisting of gray conglomeratic sandstone, occurs near anomaly 4 . The segment between anomalies 4 and 5 is covered. At the sample horizon just east of anomaly 5 a topographic bench appears and extends to about anomaly 9 , indicating that basal Chinle sandstone probably occurs throughoui the segment, but is absent to the west and east. A few outcrops corroborate the interpretation. Outcrops are scarce in the segment from anomalies 9 to 15 ; those that occur indicate, with a few exceptions, that massive sandstone is generally either absent or only a few feet thick. Relatively continuous thick sandstone crops out from just west of anomaly 16 eastward for hundreds of yards beyond the sampled trees. No anomalous radio- 
activity was noted anywhere along this outcrop (pl. 9) but colluvium covers the contact of the Moenkopi and Chinle formations.

\section{RESULTS OF PHYSTCAL EXPLORATION AT BOTANICAL ANOMALIES}

In 1955 , stripping removed overburden in the part of the tested sector from botanical anomalies 7 to 9 , but did not everywhere expose the basal part of the Chinle formation and its contact with the Moenkopi formation. Anomalous radioactivity of about twice background intensity was noted about 80 feet east of anomaly 7 where the stripping did expose the contact. Road cuts at anomalies 10 and 11 expose rock that lacks the lithology of a typical uraniferous unit. In 1955 , removal of overburden at anomaly 12 exposed a thick sequence of siltstone and sandstone at the base of the Chinle, the lowest part of which has radioactivity as much as 10 times background intensity. The tree containing a reliably anomalous amount of uranium (anomaly 12 , table $10 D$ ) was sampled after stripping and may have been contaminated by uraniferous dust. Although there had been no physical exploration at anomaly 16 when it was last examined in 1955, an ore deposit was being exploited about 400 feet to the northwest in the same sandstone or a unit related to that underlying anomaly 16 .

\section{Results and Conclusions of botanical prospecting}

Sixteen botanical anomalies occur along about 3.0 miles of horizon tested by botanical prospecting. Eight are reliable; the rest are of indeterminate reliability (table 10D). Based on geological criteria, anomalies $5-8,9,12$, and 16 are the most likely ones to contain ore deposits (table 11D) The most reliable anomalies generally coincide with those considered most favorable for containing ore deposits.

Shallow drilling behind the outcrops at all of the anomalies considered likely to contain ore deposits is justified. Shallow drilling is also justified at anomalies 4,14 , and 15 because they may lie on the flank of unexposed thick channel-fill units. A few holes could test whether or not the rocks at these anomalies have thicker mineralized extensions to the south. Long segments of the tested horizon do not warrant more exploration because they do not have any botanical anomalies or rocks considered favorable for containing ore deposits.

There is good correlation between botanical anomalies and places considered favorable on the basis of geologic criteria for containing ore deposits (fig. 12). A notable exception occurs near the east end of the tested horizon between anomalies 15 and 16. A favorable locality, now marked by a mine, was found here in 1954 by geologic and radioactivity investigations, but trees sampled directly above and adjacent to the deposits contained normal amounts of uranium. Some trees appeared to be rooted right in the deposit. The reason for the lack of 


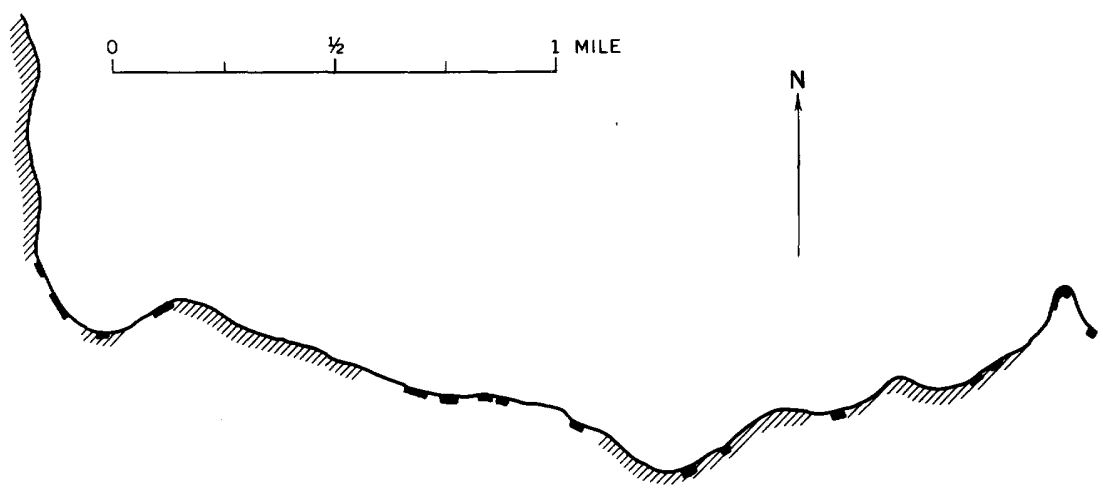

EXPLANATION

Sample horizon

Botanical anomalies

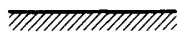

Ground considered unfavorable for containing ore deposits, based on geology

FigURE 12.-Relations between botanical anomanes and ground considered favorable on the basis of geologic criteria for containing ore deposits, subarea 4, South Elk Ridge, San Juan County, Utah.

sensitivity by the trees remains an enigma. It should be noted here that practically all sampling in subarea 4 preceded physical exploration, so that contamination of samples by uraniferous dust presented no problem.

Places of anomalous radioactivity at the sample horizon do not correlate well with botanical anomalies as shown below:

Number of occurrences

Exact coincidence of anomalous radioactivity ${ }^{1}$ at the sample horizon with botanical anomalies

Noncoincidence:

No anomalous radioactivity detected at botanical anomalies_-_- 9

No botanical anomalies at localities of anomalous radioactivity ${ }^{2}-8$

Total noncoincidence

1 Anomalous radioactivity is that amount which is twice background intensity.

2 The number of occurrences in this category is only approximate because the locality of anomalous radioactivity has arbitrary limits.

A lack of correlation generally can be accounted for by thick colluvium that absorbs the radiation, by inadequate radioactivity surveys, by an inadequate density of tree samples, or by a sample horizon that is locally too far above or below the radioactive locality.

The botanical anomalies range in maximum lengths from 50 to 360 feet, most having a maximum length of 50 feet (table 9). Based on the total maximum lengths, botanical anomalies constitute about 10 percent (1,600 feet) of the total length of sampled horizon. Anom- 
alies rated favorable for containing ore deposits constitute about 6 percent of the sampled horizon, or a smaller percent if that part of the horizon is included which was examined but not sampled because of its extreme unfavorableness (pl. 9).

Sandstone may underlie about 50 to 65 percent of the length of tested sample horizon. A maximum of about 60 percent of the sandstone could be ore bearing, based on geologic criteria; however, botanical anomalies indicate that only 10 percent might contain ore, to which might be added another 3 percent indicated by anomalous radioactivity. In general, the tested part of subarea 4 is relatively unfavorable for containing ore deposits except for a few small sectors, where the chance for finding ore deposits is good (table 11D).

\section{SUBAREA 5 (WOODENSHOE CANYON)}

The tested part of subarea 5, about 6 miles long, includes both sides of Woodenshoe Canyon from its head north to about $37^{\circ} 42^{\prime} 30^{\prime \prime} \mathrm{N}$. latitude (pl. 9). Most of the tested horizon is accessible only by walking and climbing down from roads on the Moss Back member of the Chinle formation; however, roads reach the test horizon at prospects and strippings in the vicinity of anomalies 4-6.

The canyon slopes are steep and covered in their lower parts by a dense forest of pinyon, juniper, and scrub oak. Salients of chiefly ponderosa pine and Douglasfir locally extend downward into the pinyon-juniper-oak zones, showing their best development along the sample horizon near the canyon head where the slopes face north and east. All of the evergreens mentioned above were sampled; junipers and pinyons were the types most sampled.

The author has examined only botanical anomalies 4 and 6 and vicinity; consequently, the evaluation of botanical-prospecting data is based chiefly on field notes made by A. J. Froelich and W. R. Martin.

\section{GENERAL GEOLOGY}

Sandstones rubble along the sample horizon from about anomalies 1 to 13 indicates that sandstone at the base of the Chinle is probably fairly continuous between these anomalies. North of botanical anomaly 1 to at least the northeast sample limit sandstone is absent. Between anomalies 1 and 6 the unit occurs as broad lenses that average about 400 feet in outcrop length and 15 to 25 feet in thickness. Series of lenses are superposed at places, as in the vicinity of anomalies 5 and 6 , where a prominent and probably discontinuous sandstone above the base of the Chinle formation channels into a mudstone unit of the Chinle and at places rests on a basal sandstone of the Chinle (A. J. Froelich, field notes). Cover between anomalies 6 and 8 generally 
conceals parts of the basal sandstone of the Chinle, particularly near the unit's upper contract, but the sandstone seems to be relatively continous. Near anomaly 6 this unit is as much as 35 feet thick, and a thickness of about 20 feet was estimated near anomaly 8 . The sandstone appears to be generally thicker between anomalies 6 and 8 than northward to the sample limits. Based on poor exposures between anomaly 10 and the northwestern limit of sampling, the sandstone may average only about 10 feet thick.

\section{RESULTS OF PHYSICAL DXPLORATION AT BOTANICAL ANOMALIES}

Removal of overburden, done many months after plant sampling, has exposed the contact of the Chinle and Moenkopi formations and an overlying 20 -foot-thick sandstone lens that is mineralized in its lowest few feet at the approximate location of botanical anomaly 4 . This discovery of mineralized rock, where an anomaly is indeterminate in reliability (table $10 E$ ) when classified on the basis of plant-sample results, emphasizes the fact that anomalies of indeterminate reliability are worthy of physical exploration, particularly if they occur in an area considered favorable for uranium deposits.

Anomaly 6 (East Woodenshoe claim) probably should be classed as an apparent anomaly. Only one tree contains an anomalous amount of uranium (2.5 $\mathrm{ppm})$, but that may be due to contamination by dust from stripping operations, because nearby randomly sampled trees, some closer to known mineralized rock, contain only normal amounts of uranium (fig. 13). The stripping has exposed a mineralized sandstone lens 2 feet thick, located about 35 feet above the top of the Moenkopi formation. Samples from the lens contain as much as 0.22 percent $\mathrm{U}_{3} \mathrm{O}_{8}$ (Richard Q. Lewis, Sr., written communication, 1954).

\section{ResUlts and Conclusions of Botanical PROSPECTING}

Plant-analysis prospecting along about 6 miles of ore horizon at the head of Woodenshoe Canyon found only 13 botanical anomalies. Seven of the anomalies are of indeterminate reliability; the others are of moderate to good reliability, but are small in extent (tables 9 and $10 \mathrm{E}$. Most of the least reliable and indeterminately reliable anomalies are on the west side of Woodenshoe Canyon; none of these have more than 2 and most have only 1 tree containing indeterminately anomalous amounts of uranium (table $10 E$ ). Little is known concerning the lithology and structures of the basal Chinle rocks along the west side of the canyon because exposures are scarce. The few exposures unreliably indicate that the best potential host rocks generally lie near the canyon head. Uranium deposits are known on the east side of the canyon in basal Chinle rocks; at several of these 

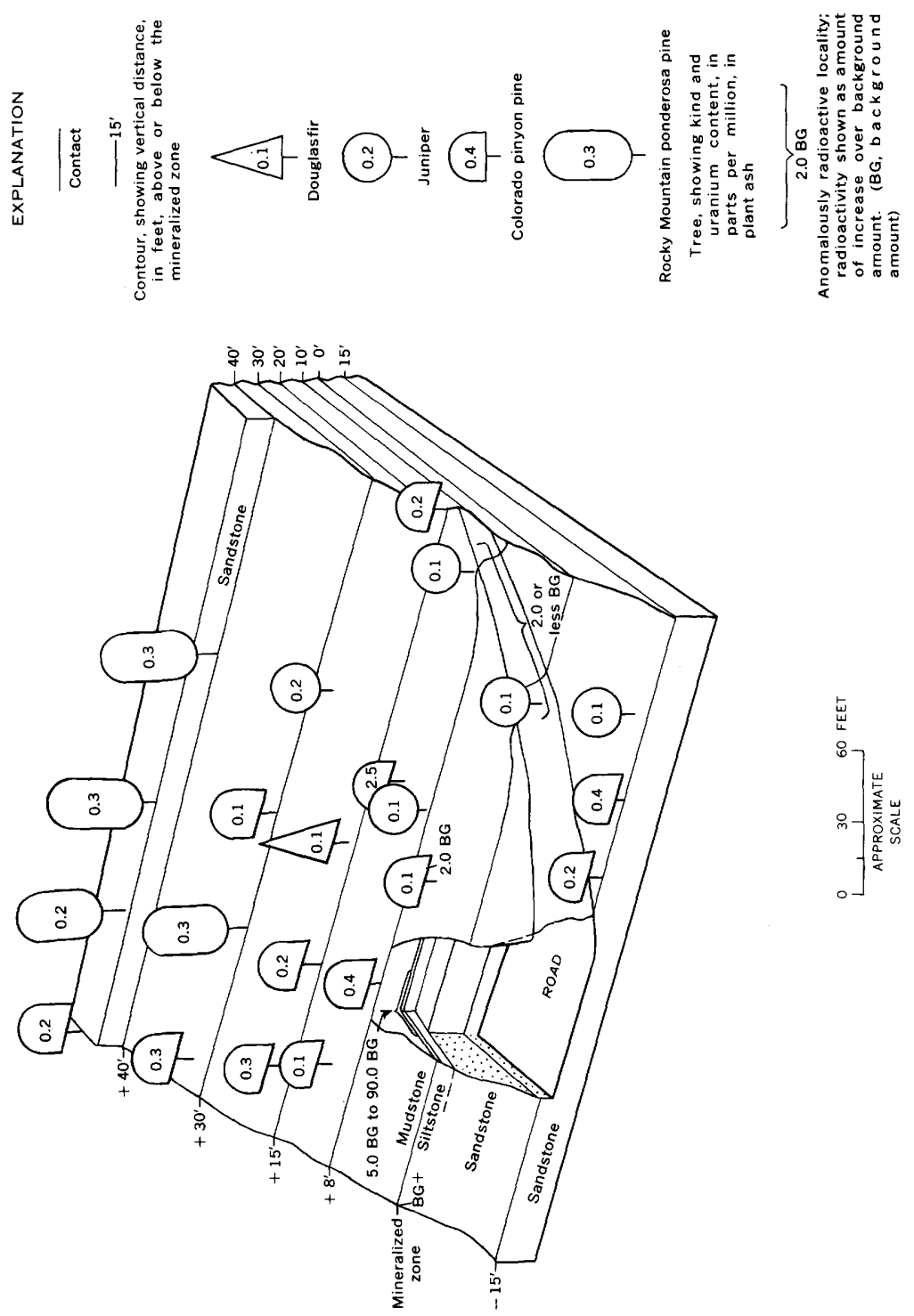

Figdre 13.- Results of control sampling at the East Woodenshoe claim, botanical anomaly 6, subarea 5, South Elk Ridge, San Juan County, Utah (A. J. Froelich, written communication, 1953). 
localities the rocks appear to have some structures favorable for containing ore deposits (table $11 E$ ). This justifies more exploration at all the eastern anomalies. On the west side, anomalies 8,11 , and, to a lesser degree, 12 , justify more exploration, particularly because the sandstone at these places may have favorable structures and thicknesses. Other anomalies on the west side of the canyon may not be as favorable for containing ore deposits; this suggestion is based chiefly on inferences that the sandstone is persistently thin.

Botanical anomalies constitute about 3 percent (950 feet) of the total horizon length tested, and most of the 3 percent lies on the east side of the canyon. A map by R. Q. Lewis, Sr., and W. J. Krummel, Jr. (written communication, 1954) shows that the Shinarump, mostly sandstone, constitutes about 25 percent (1.5 miles) of the total horizon length tested. Assuming that all the botanical anomalies coincide with this sandstone, they indicate that a maximum of only about 12 percent of it contains anomalously large amounts of uranium. Based on geologic criteria at the anomalies, though, only about 10 percent (800 feet) of the sandstone has a fair chance for containing ore deposits. Consequently, the Woodenshoe Canyon subarea is considered relatively unfavorable for more testing, except at those anomalies previously cited.

\section{SUBAREA 6}

The sample horizon in subarea 6 lies along a slope on the south side of South Elk Ridge (pl. 9) which rises precipitously above the Grand Gulch Plateau. Ecology is generally similar along the horizon because altitude remains nearly constant, ranging vertically from about 7,600 feet in the northwest to about 7,800 feet in the southeast. A woodland forest (pinyon pine and juniper) dominates the slope, but trees of the montane forest, such as ponderosa pine and Douglasfir, and deciduous trees and shrubs grow locally. Sampling was restricted chiefly to pinyon pine and juniper because of their abundance.

Most of subarea 6 was tested with samples spaced 50 to 70 feet apart, but where rocks at the sample horizon were anomalously radioactive along extensive sectors of slope or where basal sandstone of the Chinle was known to be absent or less than 5 feet thick, samples were spaced 100 to 200 feet apart or taken at much greater intervals for control purposes.

Because botanical prospecting was completed before large-scale prospecting and mining activity began here, contamination of the sampled trees by uraniferous dust was not an important factor in interpreting sample results.

In 1955, roads built to drill and stripping sites along the sample horizon made access easy to botanical anomalies 1-4, 8-11, and 15-17. 


\section{GENERAL GEOLOGY}

Rocks at the sample horizon are better exposed than in the other subareas; however, colluvium covers much of the horizon in the heads of the big reentrants which are at or near anomalies $1,8,10$, and 18 . Also, at most of the botanical anomalies the critical contact between the Moenkopi and Chinle formations is covered, and it can only be inferred whether or not sandstone of the Chinle fills channels cut in the top of the Moenkopi.

Basal sandstone of the Chinle crops out as discontinuous lenses which are generally hundreds of feet long and which range in maximum thickness from 1 to about 40 feet. Most of the outcrops are relatively thin compared to their lengths, as the one at anomaly 9 , which is more than 800 feet long and only about 30 feet thick. Some basal sandstones have irregular bottoms with relief ranging from about 1 to 10 feet. Locally these thickened places at the base of the lenses resemble filled channels.

At most places the basal sandstone of the Chinle forms one distinct resistant ledge. The unit is typically grayish white or light tan, massive and cross-stratified, moderately well cemented, and fine to coarse grained. It contains moderate amounts of interstitial silt, a few gray or variegated purple and white siltstone lenses, and conglomerate stringers and lenses. In some places the lowest Chinle rocks are sequences of interstratified sandstone and siltstone and form a series of thin shelving ledges. The sandstone generally grades laterally and vertically into thin-bedded or structureless white to variegated purple and white siltstone and ferruginous poorly sorted sandstone of the lower Chinle. This sequence is overlain by variegated light gray to purplish claystone and siltstone, but in some places the claystonesiltstone sequence rests directly on the Moenkopi.

\section{RESULTS OF PHYSICAL EXPLORATION AT BOTANICAL ANOMALIES}

The local occurrences at botanical anomaly 1 of favorable lithology and sedimentary structure and of anomalous radioactivity all indicated that an ore deposit might have been present (table 11F), but drilling for the Geological Survey in 1955 found only mineralized rock, most of which is in pyritic carbonaceous and silty sandstone above the basal channel-fill unit. Geological Survey drill holes at the trees which define anomaly 2 indicated that only colluvium about 30 feet thick covers the Moenkopi formation. However, the erosion which has dissected Elk Ridge may have removed basal sandstone of the Chinle formation from the location of the tree samples at anomaly 2 prior to covering by colluvium, so drilling has not ruled out the presence of sandstone farther away from the side of the canyon. 
Drill holes collared further upslope should penetrate bedrock overlying the Moenkopi, but more drilling is not justified because ore was absent in the rock tested at anomaly 1 and because more reliable botanical anomalies than anomaly 2 are present to the south. Removal of overburden in $\mathbf{1 9 5 5}$ from the slope in the vicinity of anomaly 4 exposed mineralized channel-fill-type sandstone and siltstone. It is thought that the tree containing anomalous uranium, knocked down during stripping operations, coincides in position with the most intensely mineralized rock exposed. Stripping did not completely expose the mineralized unit, and an ore deposit may still be found. In 1955 the Geological Survey removed overburden from anomaly 9 to expose the contact of the Moenkopi and Chinle but only a few spots of weakly mineralized rock were found; consequently, additional physical exploration is probably not warranted until other more favorable anomalies are tested. Uranium-ore deposits may be found here yet, however, because a sandstone at the base of the Chinle fills a broad depression as much as 7 feet deep in the top of the Moenkopi. Any additional exploration should be drilling designed to test for more favorable lithology in an extension of the filled depression. At botanical anomaly 17, stripping of overburden in 1955 exposed a broad sandstone lens, locally mineralized, that may be lying in a scour in the top of the Moenkopi formation.

\section{RESULTS AND CONCLUSIONS OF BOTANICAL PROSPECTING}

Twenty-four botanical anomalies were found along about 5.2 miles of ore horizon tested by botanical prospecting. Fifteen have differing degrees of reliability; the rest are of indeterminate reliability (table $10 F)$. Based on geologic criteria, anomalies 4-8, 11-18, 20, and 22-24 appear to be the most likely ones to contain ore deposits (table $11 F$ ). In general, the anomalies considered most favorable for containing ore deposits are reliable anomalies. There is good correlation between ground with botanical anomalies and ground considered favorable by geologic criteria for containing ore deposits, but there appears to be only a fair correlation between anomalous radioactivity and botanical anomalies as shown below:

Exact coincidence of anomalous radioactivity ${ }^{1}$ at the sample occurrences

horizon with botanical anomalies

Noncoincidence :

No anomalous radioactivity detected at botanical anomalies.----

No botanical anomalies at localities of anomalous radioactivity ${ }^{2}$

Total noncoincidence.

1 Anomalous radioactivity is that amount which is twice background intensity.

2 The number of occurrences in this category is only approximate because the locality of anomalous radioactivity has arbitrary limits. 
The botanical anomalies range in length from 50 feet to more than 600 feet; most range in length from 50 to 200 feet (table 9). Based on the total lengths, botanical anomalies comprise about 15 percent $(4,125$ feet) of the total length of sampled horizon. Reliable anomalies and anomalies rated relatively favorable for containing ore deposits each constitute about 9 percent of the sampled horizon. Sandstone may underlie a maximum of about 75 percent $(3.9$ miles $)$ of the length of sampled horizon, and a maximum of about 90 percent ( 3.5 miles) of the sandstone is 10 feet or more thick. Based on the distribution and sizes of botanical anomalies and geologic criteria at their loci, about 12 percent of the sandstone appears favorable for containing ore deposits. Geologic criteria and anomalous radioactivity indicate that another 5 percent of the sandstone might contain ore deposits.

The ease of sandstone demarcation and the large percentage of sandstone favorable for containing ore deposits permit close confinement of additional exploration to areas where the chance of ore discovery is best and decrease costs of exploration. This makes subarea 6 more attractive than most of the other subareas for additional kinds of exploration. Shallow drilling through the sandstone at the base of the Chinle is warranted at most of the anomalies considered favorable for containing ore deposits. The reliable anomalies should be tested first. A low priority is attached to physical exploration at anomalies 1, 2, and 9 because they were incompletely tested by the Geological Survey in 1955 and found not to contain ore. The most promising part of the tested horizon along which to prospect by drilling and (or) rim-stripping is that part between anomalies 11 and 16, because lithology and sedimentary structure of the rock appears to make it a very favorable host and because anomalous radioactivity was measured at many places along this part of the sample horizon. The sandstone at some of the other anomalies, particularly anomalies $5,6,7,20,22$, and 23 may, for similar reasons, contain ore deposits.

\section{SUBAREA 7 (BURCH CANYON)}

A. J. Frolich and W. R. Martin tested the basal sandstone of the Chinle formation in subarea 7 in 1953 by collecting branch-tip samples at about 100-foot intervals. The sample horizon ranges in altitude from about 7,800 to 8,000 feet and lies along steep slopes covered with pinyon-juniper forest. Sampling was generally restricted to these trees execpt along the north-facing slope near anomalies 10-12, where Douglasfir grew abundantly enough to provide the best sample media. 
During the sampling program, mining and prospecting was in progress in the NW1/4 sec. 24 , T. 36 S., R. 18 E. (pl. 9), but contamination does not seem to have affected the samples. Descriptions of geology and botanical anomalies in Burch Canyon are brief and, in places, incomplete because the author had briefly visited the sample horizon at only two localities that are not near the botanical anomalies and had to rely chiefly on field notes made during sampling by the earlier workers.

\section{GENERAL GEOLOGY}

As in other parts of South Elk Ridge, the basal sandstones of the Chinle formation at Burch Canyon are lenticular units, ranging in thickness from a knife edge to about 40 feet. The rock is similar in lithology to the sandstone in subarea 6. R. Q. Lewis, Sr., and P. H. Reitan (written communication, 1954) describe the unit in detail. In places, massive sandstone is separated into two parts by a prominent siltstone unit; only the lower part seems to contain uranium ore deposits. Carbon is abundant locally, as in the basal part of the thick sandstone that crops out in the vicinity of the prospect which lies south of anomaly 9 (pl.9).

Colluvium covers bedrock at anomalies 1 and 2 , but based on geology extrapolated into the vicinity from the west and northeast, a favorable sandstone host rock for uranium is inferred to be present. Sandstone at the sample horizon near anomaly 3 is about 6 feet thick and thickens to about 35 feet near anomaly 4 . The thickened sandstone may reflect a channel-fill unit; consequently, ore deposits may be present in the unit where it underlies the botanical anomalies. The geologic setting at anomalies 5 and 8-11 is not well known to the author; therefore, they are not classified as to their favorableness for containing ore deposits. In the vicinity of anomalies 6 and 7 ore occurs in a Shinarump-filled channel. Anomaly 12 is not classified either, because the base of the Chinle is mostly covered.

Physical exploration at Burch Canyon has been intensive and consists of underground workings, drill holes, and extensive stripping of overburden. Because the author did not do the plant sampling in this subarea and only briefly visited the prospected localities, no section on results of physical exploration is included in this report. R. Q. Lewis, Sr., and R. H. Campbell will describe those in the Burch Canyon area in more detail in a later paper.

\section{RESULTS AND CONCLUSIONS OF BOTANICAL PROSPECTING}

Twelve botanical anomalies are located within about 4.0 linear miles of tested horizon. Only three of the anomalies have good reliability 
(table 10G), but all justify, by their presence, additional investigation.

Calculated anomaly lengths show that about 6 percent of the total 4.0 linear miles of slope tested is probably mineralized. This figure is considerably less than that for subarea 6 , but is more in agreement with the percentages obtained in other subareas.

Distribution of the anomalies indicates in a general way that the most favorable ground for uranium deposits lies in the southwest, most northerly and most easterly parts of the tested horizon because the botanical anomalies are clustered at these places. Anomalies 6-9 lie in the immediate vicinity of active mining. The botanical anomalies failed to indicate known mineralized rock, some of ore grade, which crops out in two places along wide sectors of the sample horizon. The absence of anomalous uranium in sampled trees growing just over thin mineralized sandstone south of anomaly 6 cannot be satisfactorily explained. A similar absence in trees growing over sandstone south of anomaly 9 may be explained by the fact that the unit in that vicinity is extremely thick, attaining a maximum thickness of about 40 feet, and the mineralized rock is in the lowest part of the unit. The sampled trees grow at the top of the sandstone and cannot be expected to indicate such deeply located deposits.

According to R. Q. Lewis, Sr. (oral communication 1956) anomalies 2 or 3 and 12 are alined along the projected trend of a Shinarumpfilled channel. This justifies physical exploration along those parts of the channel not tested by plant-analysis prospecting.

\section{SUBAREA 8 (LYMAN CANYON)}

Twenty samples were collected along about 1,100 feet of sample horizon at the head of Lyman Canyon. Subarea 8 has ecology and geology similar to that in subareas 6 and 7 .

The only botanical anomaly found, a reliable one, coincides with mineralized rock at the base of the Chinle exposed by a short adit and a short stripped part of the slope. The slope is covered by colluvium away from the prospect. Thick sandstone at the base of the Chinle that would be favorable for containing a minable quantity of uranium is probably absent along the tested horizon.

\section{SUBAREA 9 (ARCH CANYON)}

The sampled part of subarea 9 lies at the head of Arch Canyon (pl. 9). A segment extending for about 2 miles along the sample horizon east of the tested part was examined but not sampled. A sample horizon here could not be selected or consistently maintained that would effectively test the base of the Chinle formation, because 
the horizon is covered by colluvium, possible landslide debris, and dense vegetation consisting mostly of shrubs. About 2.3 miles of sample horizon southwest of the tested part was examined but not sampled because no rock unit judged favorable for containing uranium deposits occurs at the horizon to which the sampling program was restricted. There are generally enough ponderosa pine and firs for sampling purposes growing along the test horizon.

The zone tested for uranium deposits lies along a steep, heavily wooded slope where vegetation and colluvium generally cover bedrock. The general absence at the tested horizon of a steepened slope that generally marks the typical ore-bearing unit on South Elk Ridge indicates that such a unit is absent throughout most of the subarea. Some poorly exposed rocks at the base of the Chinle appear to be unfavorable for the occurrence of uranium deposits. No uranium mines or prospects are known within a radius of about $1 \frac{1}{2}$ miles from the botanical anomalies.

In general, the head of Arch Canyon is considered unfavorable for containing uranium deposits as compared to the other subareas. Only three botanical anomalies, two of indeterminate reliability, were found in subarea 9 (table $10 H)$. The three anomalies constitute about 17 percent ( 1,100 feet) of the tested horizon which is 1.25 miles long. In general, these anomalies coincide with most of the known and inferred basal sandstone of the Chinle. None of the anomalies are rated favorable for containing uranium ore deposits because favorable lithology and sedimentary structures appear to be absent. There is poor correlation betwen botanical anomalies and anomalously radioactive localities as shown below:

Number of occurrences

Exact coincidence of anomalous radioactivity ${ }^{1}$ at the sample horizon

with botanical anomalies

Noncoincidence :

No anomalous radioactivity detected at botanical anomalies_--- 2

No botanical anomalies at localities of anomalous radioactivity ${ }^{2}-2_{2}$

Total noncoincidence

1 Anomalous radioactivity is that amount which is twice background intensity.

2 The number of occurrences in this category is only approximate because the locality of anomalous radioactivity has arbitrary limits.

\section{EVALUATION OF PLANT-ANALYSIS PROSPECTING}

Several programs were conducted to evaluate the success of locating uranium deposits and the reliability of plant-analysis and plantsampling methods. Another limited program was to relate the uranium content of trees to the content of other elements in rock and regolith. During the program to evaluate the success of locating 
uranium, it was hoped to learn something of the effects that size, spatial, and lithologic position, and grade of uranium deposits would have on the trees indicating an anomaly. Results of the programs are discussed below. All programs achieved important results, some mutually confirming, except the program to relate uranium in trees to other elements in rock and regolith.

Plant-analysis prospecting for uranium deposits defined 59 localities at Deer Flat and 110 localities at Flk Ridge as being underlain by material containing anomalously large amounts of uranium. The Deer Flat anomalies along with factors important in their interpretation are described in another chapter of this bulletin by Froelich and Kleinhampl (1960, p. 51-84). The Elk Ridge anomalies along with factors important in their interpretation are described in the preceding sections of the present report.

The success of locating uranium deposits was evaluated by examining the bedrock at and adjacent to botanical anomalies. Examination involved (a) diamond core drilling concomitant with radiometric surveying of drill holes and subsequent radiometric and uranium analyses of drill core, and (b) radioactivity testing at the surface concomitant with plant sampling. Evaluation results are summarized in the figures and tables that follow, and the text describes the evaluation procedures and the results in greater detail.

\section{SUCCESS EVALUATION BASED ON DRILLING}

\section{CHOICE OF DRILL-TEST LOCALTTIES AND DRILLING PROCEDURE}

Botanical anomalies selected for drilling in 1955 represented, chiefly, the class of anomalies of good reliability and poor to good favorableness for containing uranium deposits. Only anomalies of good reliability were drilled because financial considerations limited the number of tests. The procedure of drill testing the most reliable botanical anomalies first would be followed in any mineral exploration plan; consequently this phase is of major importance. It is to be expected that less reliable anomalies would yield less successful drilling results.

Other factors influenced the choice of anomalies for drilling. Feasibility of getting drilling equipment to the sample horizon was a major consideration. To drill some anomalies, very favorable for testing in many respects, would have required too great an expenditure of time because of difficult access. Some other anomalies were not adequately defined by sampling for evaluation purposes.

Seven botanical anomalies were selected for diamond core drilling. Three of these are at Deer Flat and include anomalies 4, 5, and 9 in the Southern Deer Flat locality, named according to the system used by 
Froelich and Kleinhampl (1960, p. 52 and pl. 6). The four anomalies tested at Elk Ridge are: Subarea 1S, anomalies 2, 16, and 17, and subarea 6 , anomaly 1 .

At each anomaly closely spaced drilling was done along a single line paralleling the line of tree samples and the cliff slope.

\section{INTERPRETATION OF DRILLING RESULTS}

Uranium content of the rock drilled is estimated in part by extrapolation from estimates of equivalent uranium oxide $\left(\mathrm{eU}_{3} \mathrm{O}_{8}\right)$ obtained by radiometric logging of the drill holes. At some places, uranium content was estimated by laboratory analysis of drill core for equivalent uranium and was measured directly by analysis for uranium. Radiometric or gamma-ray logging of holes, in common use by the Geological Survey, was generally done within a few hours of hole completion. Rock tested by gamma-ray logging is generally classified by the Survey on an economic basis as follows: ore holes contain at least 1 foot of 0.10 percent $\mathrm{eU}_{3} \mathrm{O}_{8}$ or more and mineralized holes contain less than 1 foot of 0.10 percent $\mathrm{eU}_{3} \mathrm{O}_{8}$ or more or contain at least 0.02 percent $\mathrm{eU}_{3} \mathrm{O}_{3}$ of any thickness where the grade is less than the minimum ore grade. Utilization of these figures as equivalent uranium rather than $\mathrm{eU}_{3} \mathrm{O}_{8}$ does not make an appreciable change for purposes of this report. Consequently, the gamma-ray log results are hereafter expressed as equivalent uranium rather than the originally reported $\mathrm{eU}_{3} \mathrm{O}_{8}$.

Interpretation or drilling data at botanical anomalies has been complicated by two factors. One commonly is the disparity between equivalent uranium content estimated from drill hole gamma-ray logs and equivalent uranium and uranium determined from analysis of drill core. The second is that the gamma-ray log classification of uranium content has an economic connotation, whereas the uranium contents actually delimiting barren and mineralized rock are considerably less and are established from norms of frequency distributions of actual contents, divorced from the economic implication. Each of these factors may significantly alter drilling interpretations. Because of this, two interpretations, both valuable, are presented. Both are based on the same botanical anomalies and drill holes. The first mainly utilizes the gamma-ray log classification of mineralized ground and is important to the mining industry because of the emphasis on economics. The second interpretation utilizes an adjusted classification, based on statistically derived limits, that eliminates the economic factor from the classification and which approximately accounts for disparity in gamma-ray log-estimated and laboratory-determined uranium contents. 


\section{INTERPRETATION BASED ON GAMMA-RAY LOG DATA}

A three-way comparison of drilling results is made that utilizes drill-hole data based on the same method of testing and reporting (estimates of $\mathrm{eU}_{3} \mathrm{O}_{8}$ from gamma-ray logs) : (a) a comparison of the success in locating mineralized localities by plant-analysis prospecting and by widely spaced drill sites, (b) a comparison of the success in drilling closely spaced mineralized holes at botanical anomalies and at geologically selected channels where mineralized rock is known to occur, and (c) a comparison of uranium content of rocks with uranium content of sampled trees. These results are summarized in table 5 and figures 14, 15, and 16.

As most of the comparisons to follow utilized drill-hole data based on the same method of testing and reporting, it is inferred that the comparisons are valid. However, the proximity to the canyon rims of the holes drilled in botanical anomalies compared to the other holes may introduce another variable which is the oxidation state of the uranium deposits. Thus, the interpretation of drilling data based on laboratory analysis of drill core, rather than on gamma-ray log data, is more reliable.

That the botanical anomalies define mineralized ground is indicated by the comparisons shown in table 5 . This table compares the success of finding mineralized rock at seven botanical anomalies with that at widely spaced drill sites in areas of unknown favorableness. Each widely spaced drill site can be considered as a random locality at the base of the Chinle formation and each botanical anomaly as a selected locality. But based on geologic criteria, the rocks underlying the botanical anomalies represent all degrees of favorableness for containing minable quantities of uranium. Because of this, they too, can be considered as a random selection. The comparison indicates that drilling at botanical anomalies is about four times as successful as random drilling in locating mineralized material and that all botanical anomalies are indicative of mineralized material.

TABLE 5.- Uranium in basal rocks of the Chinle formation at botanical anomalies and at widely spaced drill sites

[Drill-hole localities based on drilling for U. S. Geological Survey, 1955]

\begin{tabular}{|c|c|c|c|c|c|}
\hline \multirow{3}{*}{ Test localities } & \multirow{3}{*}{$\begin{array}{c}\text { Number of } \\
\text { tests }\end{array}$} & \multicolumn{4}{|c|}{ Percent of localities containing- } \\
\hline & & \multirow{2}{*}{ Ore } & \multicolumn{2}{|c|}{ Mineralized } & \multirow{2}{*}{ Barren } \\
\hline & & & Strong & Weak & \\
\hline \multicolumn{6}{|c|}{ Determined by garma-ray drill-hole logging } \\
\hline $\begin{array}{l}\text { Botanical anomalies } \\
\text { Widely spaced drill holes } \ldots \ldots \ldots \ldots\end{array}$ & $\begin{array}{r}7 \\
51\end{array}$ & $\begin{array}{l}0 \\
2\end{array}$ & \multicolumn{2}{|c|}{$\begin{array}{r}100 \\
20\end{array}$} & $\begin{array}{r}0 \\
78\end{array}$ \\
\hline \multicolumn{6}{|c|}{ Determined by core analysis and by adjusted ganma-ray log results } \\
\hline $\begin{array}{l}\text { Botanical anomalies } \\
\text { Widely spaced drill holes }\end{array}$ & $\begin{array}{r}7 \\
51\end{array}$ & $\begin{array}{l}0 \\
2\end{array}$ & $\begin{array}{l}14 \\
14\end{array}$ & $\begin{array}{l}86 \\
28\end{array}$ & $\begin{aligned} 0 \\
5 ?\end{aligned}$ \\
\hline
\end{tabular}


The success of finding mineralized rock by closely spaced drilling at the seven botanical anomalies is compared with closely spaced drilling at four Shinarump-filled channels (fig. 14), which were selected

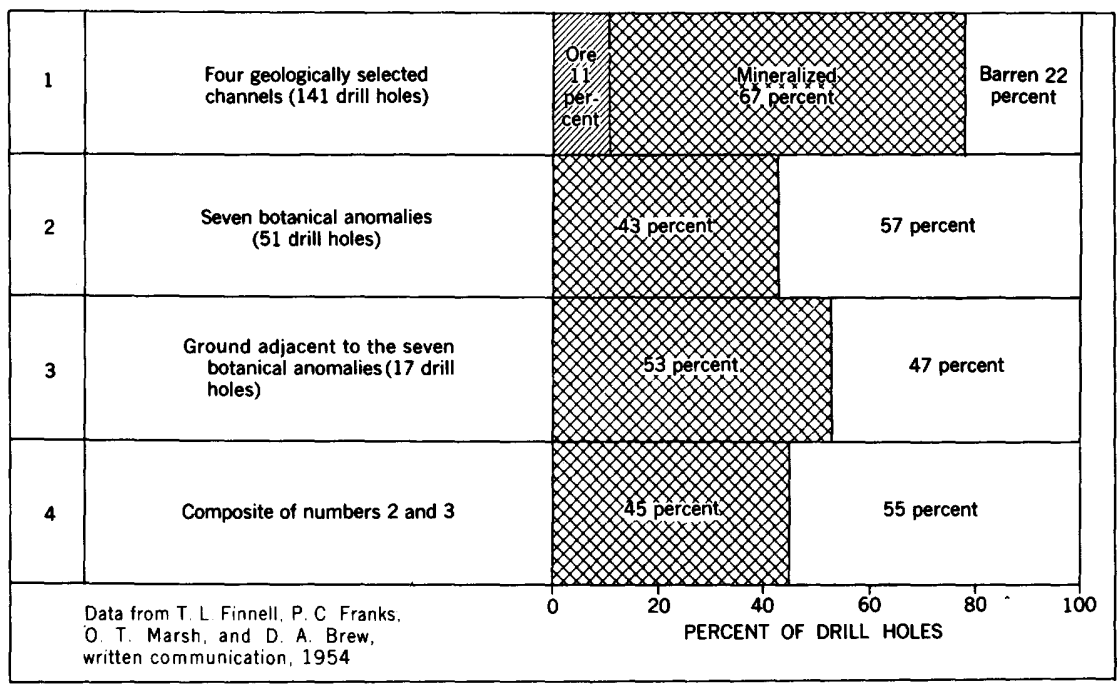

Figure 14.-Results of closely spaced drilling at geologically selected channels and at randomly selected botanical anomalies, based on gamma-ray log data, Deer Flat-Elk Ridge area, Utah.

for drilling because of their known favorable structure, lithology, and mineralized rock at the outcrop (T. L. Finnell, oral communication, 1955). This comparison indicates that closely spaced drilling at botanical anomalies (line 4, fig. 14) is only about one-half as successful as similar drilling at geologically selected channels (line 1, fig. 14). By choosing only reliable botanical anomalies and using only the best of these, based on geological criteria, a procedure not adhered to in the study made, the success of drilling botanical anomalies can approach that of drilling selected channels.

Fifty-one holes were drilled within the seven botanical anomalies (line 2, fig. 14), and 17 holes were drilled just outside the lateral limits (line 3, fig. 14). As seen from the figure, both groups have similar percentages of barren and mineralized holes. Because of this, and because the lateral limits are somewhat arbitrary, it is concluded that the botanical anomalies cannot be relied on to define the precise position of uranium deposits. At four tested anomalies, uranium contents of spatially related rocks and trees seem to lack good positive or negative correlations. These anomalies include all those drilled at Deer Flat and anomaly 1 in subarea 6, Elk Ridge. Some of the in- 
determinate correlations at Deer Flat may be due to inadequate numbers of tree samples or to slight differences in vertical separation of sampled trees with respect to mineralized rock. At anomaly 16, subarea 1-S on South Elk Ridge, there is a good negative correlation between the uranium contents of spatially related rocks and trees. The negative correlation may be only apparent, because downward leaching of uranium from mineralized zones overlying the tested horizon could account for the uranium contents of the trees.

At two localities, anomaly 2 and 17, subarea 1-S, Elk Ridge, the correlation in uranium contents is good in detail between spatially related rocks and trees (figs. 15 and 16). The plan and profile of
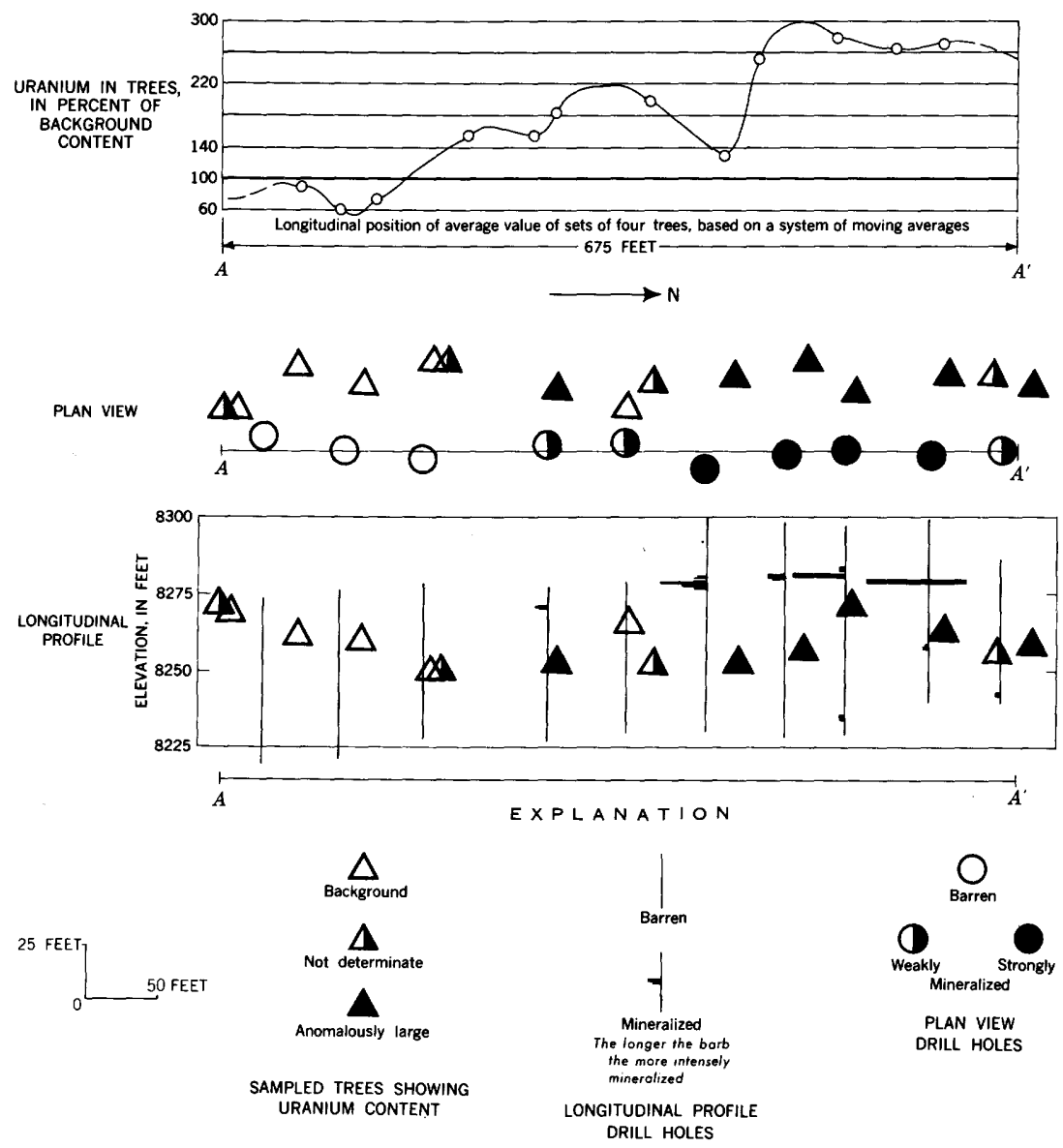

Figure 15.-Plant-sample results compared to gamma-ray logs of drill holes at botanical anomaly 17, subarea 1-S, Elk Ridge, Utah 

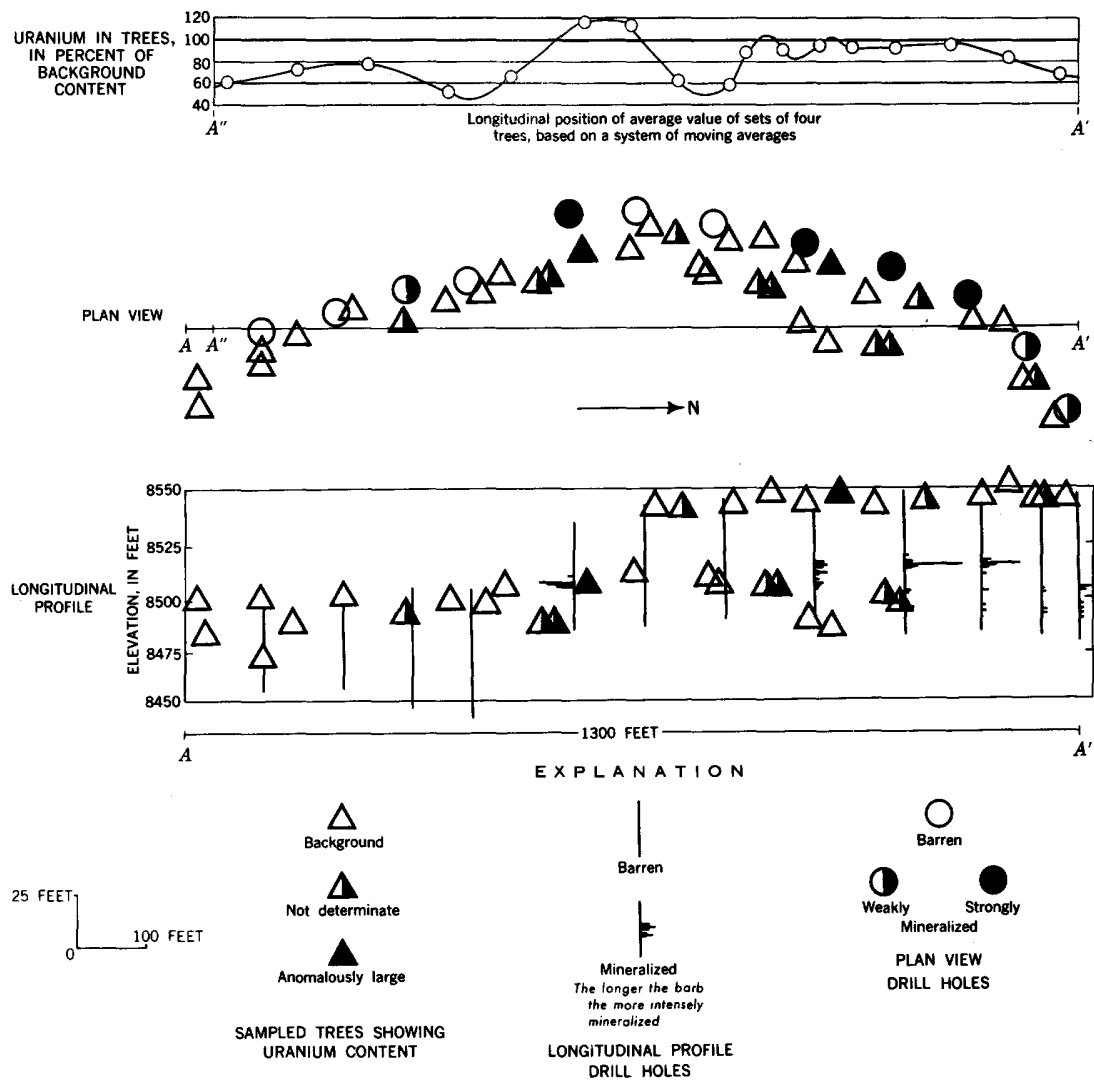

Fig URE 16.-Plant-sample results compared to gamma-ray logs of drill holes at botanical anomaly 2, subarea 1-S, Elk Ridge, Utah.

figures 15 and 16 show the relations of spatial position and uranium content of rocks and trees. The curve at the top of each figure connects points which represent the average uranium content of sets of four successive tree samples. The sets of trees are overlapping and in figure 15 are displaced one tree for each successive set and in figure 16 are displaced two trees. A choice of displacement of trees in a set alters the shape of the curve locally, but its general shape is maintained (fig. 17). The same is true by choosing different numbers of trees in a set (not illustrated).

Each curve, then, represents uranium content of trees throughout the length of the tested locality; the end points of a curve represent the lateral limits of the botanical anomaly. The significant features of the curve are its shape and contrasting ordinate values. Uranium content for each tree was calculated as a percent of the upper cutoff for background uranium content (table 3 ). This was made necessary 


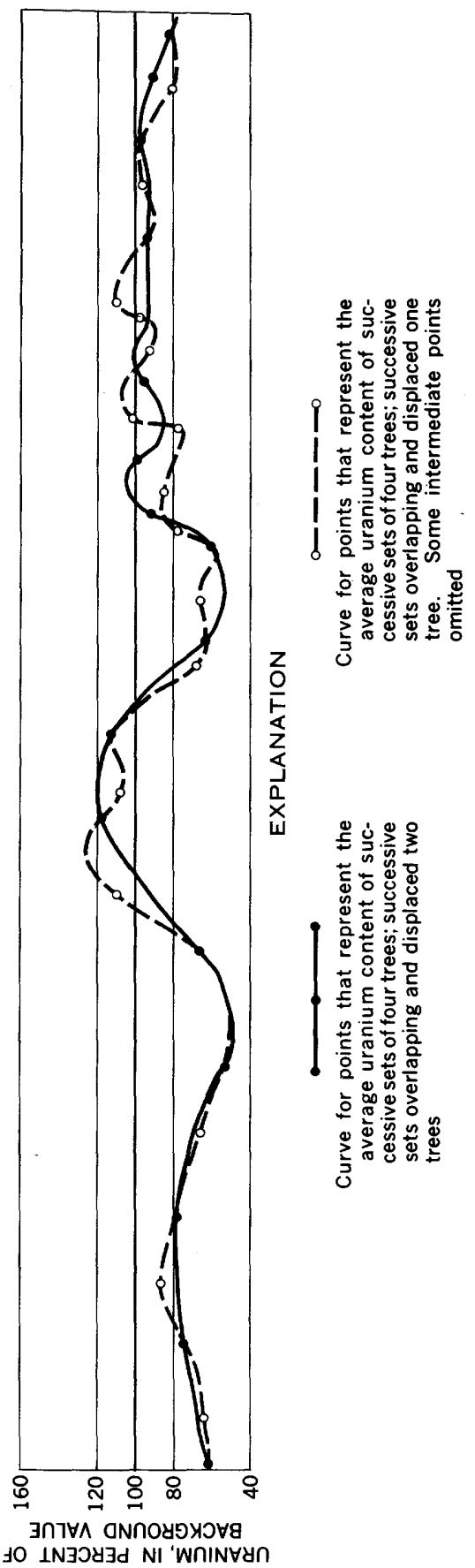

Frgore 17. - Comparison of curves each of which sbows, in a slightly different manner, the uranium content of trees sampled in a line across botanical anomaly 2, subarea 1-S, Elk Ridge (see fig. 16). 
because mixed tree types were sampled at each anomaly and most types were found to have slightly different background uranium contents. Where lithology is nonhomogeneous, as is the case particularly at the anomaly shown in figure 16, complexities may be expected in the availability and circulation of moisture, root penetration, and absorption of nutrients, and these generally decrease the preciseness of definition of uranium deposits by tree samples (compare figs. 15 and 16).

\section{INTERPRETATION BASED ON ACTUAL URANIUM CONTENT OF DRILL CORE AND ON AN ADJUSTED ROCK CLASSIFICATION}

Drilling results are adjusted in this interpretation to account for disparity in many gamma-ray log determinations of equivalent uranium contents and corresponding laboratory-determined equivalent uranium and uranium contents. Actual uranium contents are used wherever available, because nearly all the mineralized parts of drill holes as indicated by the gamma-ray logs are more intensely mineralized compared to equivalent uranium and uranium analyses of drill core from corresponding places in the hole. The differences in equivalent uranium between core and gamma-ray logging of the holes range in amount from about 2 to 25 times. Differences between equivalent uranium determined from gamma-ray logging and uranium determinations from core are even greater, ranging from 2 to 125 times. The differences in values obtained by testing of holes and cores are probably due to multiple factors, such as the presence of a radioisotope of short half life, and local poorly consolidated friable rocks. The latter lead to poor core recovery from some of the most intensely mineralized zones and to irregularly shaped drill holes, which alter the geometrical relations of hole to gamma-ray probe and invalidate factors used to convert counts per minute to equivalent uranium.

Studies of two sets of uranium analyses, that from botanical anomaly drill core and that from some barren sandstone samples collected by W. L. Newman (written communication, 1955) from the Shinarump and Moss Back in the same area, indicate that $10 \mathrm{ppm} \mathrm{U}$ and about $20 \mathrm{ppm}$ eU represent the upper limit of background uranium contents. The following interpretation of drilling results utilizes actual uranium analyses along with equivalent uranium analyses of drill core (where uranium analyses were not available), rather than gamma-ray log data. The interpretation is based on the studies cited above, which provide the means to classify rock as mineralized or barren. The classification was extended by adding some arbitrarily defined categories to permit a better evaluation of drilling results. The added categories include weakly mineralized rock, which contains more uranium than barren rock but less than 0.05 
percent; strongly mineralized rock, which contains uranium ranging in amount from 0.05 to 0.099 percent where the rock is more than 1 foot thick or uranium in any amount more than 0.05 percent where the rock is less than 1 foot thick; and ore, where the uranium content is 0.10 percent or more.

A comparison of the success of finding mineralized rock at the botanical anomalies and at widely spaced drill sites in areas of unknown favorableness shows that plant-analysis prospecting is about twice as successful as random drilling in locating mineralized rock (table 5). This comparison does not favor botanical prospecting as much as the adjacent comparison which was based only on gammaray logging results. All tested bötanical anomalies contain some mineralized rock.

Comparison of the 51 holes drilled within botanical anomalies to those 17 holes drilled just outside the lateral limits of the anomalies shows a closer similarity between percentages of barren and mineralized holes (fig. 18, lines 2 and 3) than when the same holes were

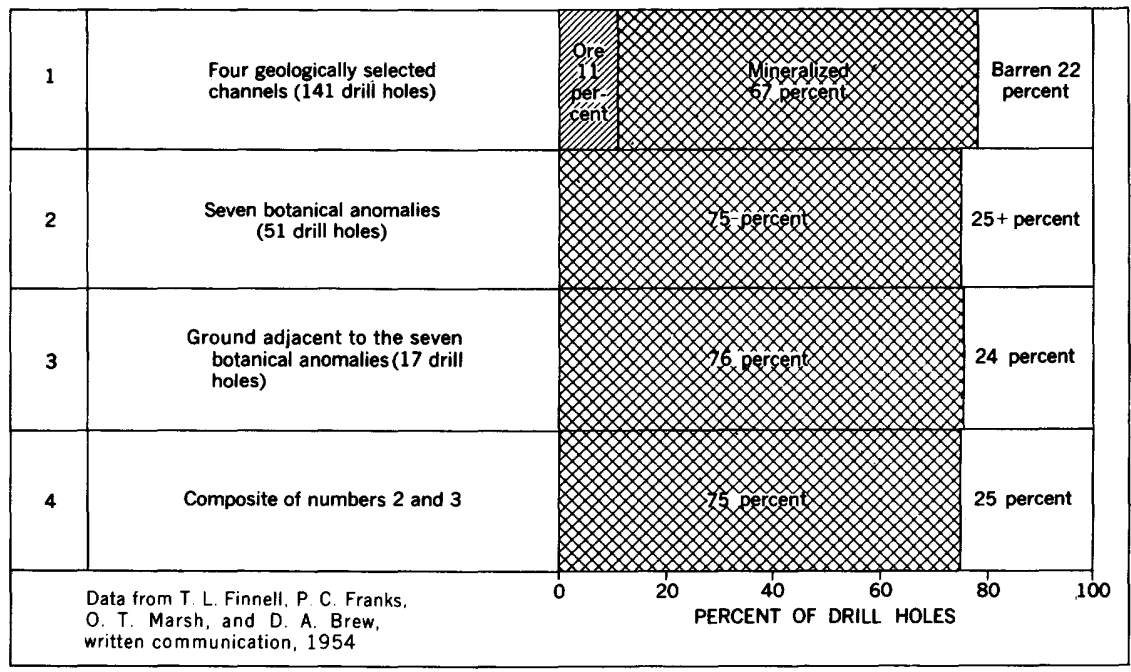

FIGURE 18.- -Results of closely spaced drilling at geologically selected channels and at randomly selected botanical anomalies, based on core analysis and adjusted gamma-ray $\log$ results.

compared chiefly on the basis of gamma-ray log data (fig. 14, lines 2 and 3$)$.

The success of closely spaced drilling at botanical anomalies (line 4, fig. 18) is probably slightly more than three-fourths to almost equally as successful as similar drilling at geologically selected Shinarump-filled channels (line 1, fig. 18). The wide range of rating for the comparative degree of success is necessitated because the "barren" 
part of line 1 (fig. 18) is determined from the gamma-ray log classification (no core analyses were made for holes indicated as barren by gamma-ray logging), and probably includes some mineralized holes according to an actual uranium content classification, which is used for lines 2, 3, and 4 (fig. 18). The comparative success ratings show a 50 to 100 percent improvement in favor of drilling botanical anomalies compared to the less realistic success rating based on unadjusted gamma-ray log data (fig. 14).

When the drilling data for uranium content of the rocks is adjusted, figures 15 and 16 are altered to figures 19 and 20, respectively. For
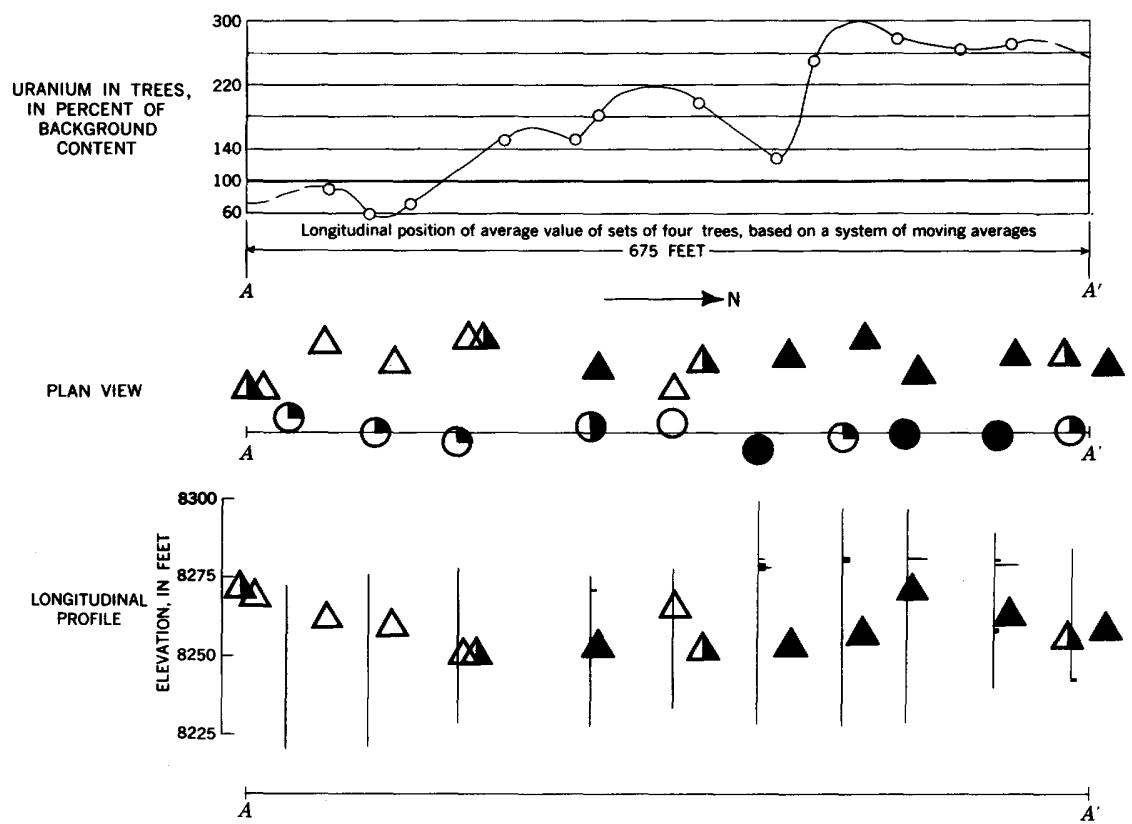

EXPLANATION

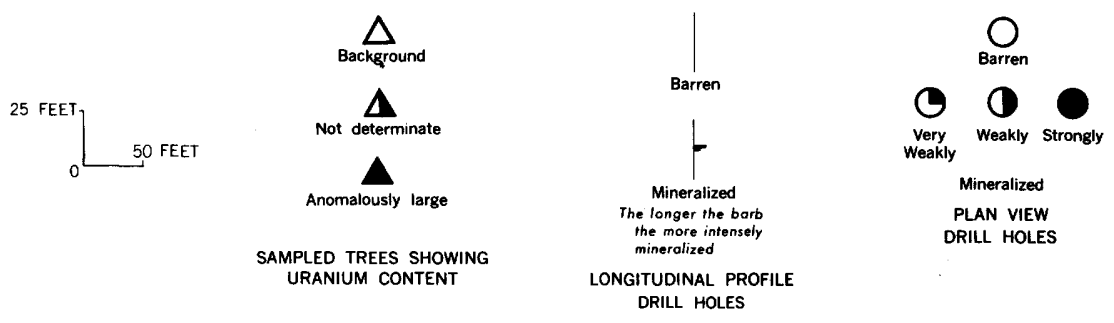

Figure 19.-Plant-sample results compared to adjusted drilling data at botanical anomaly 17, subarea 1-S, Elk Ridge, Utah.

the anomalies shown, as well as for the other five drilled ones, correlations between uranium contents of spatially related rocks and trees 


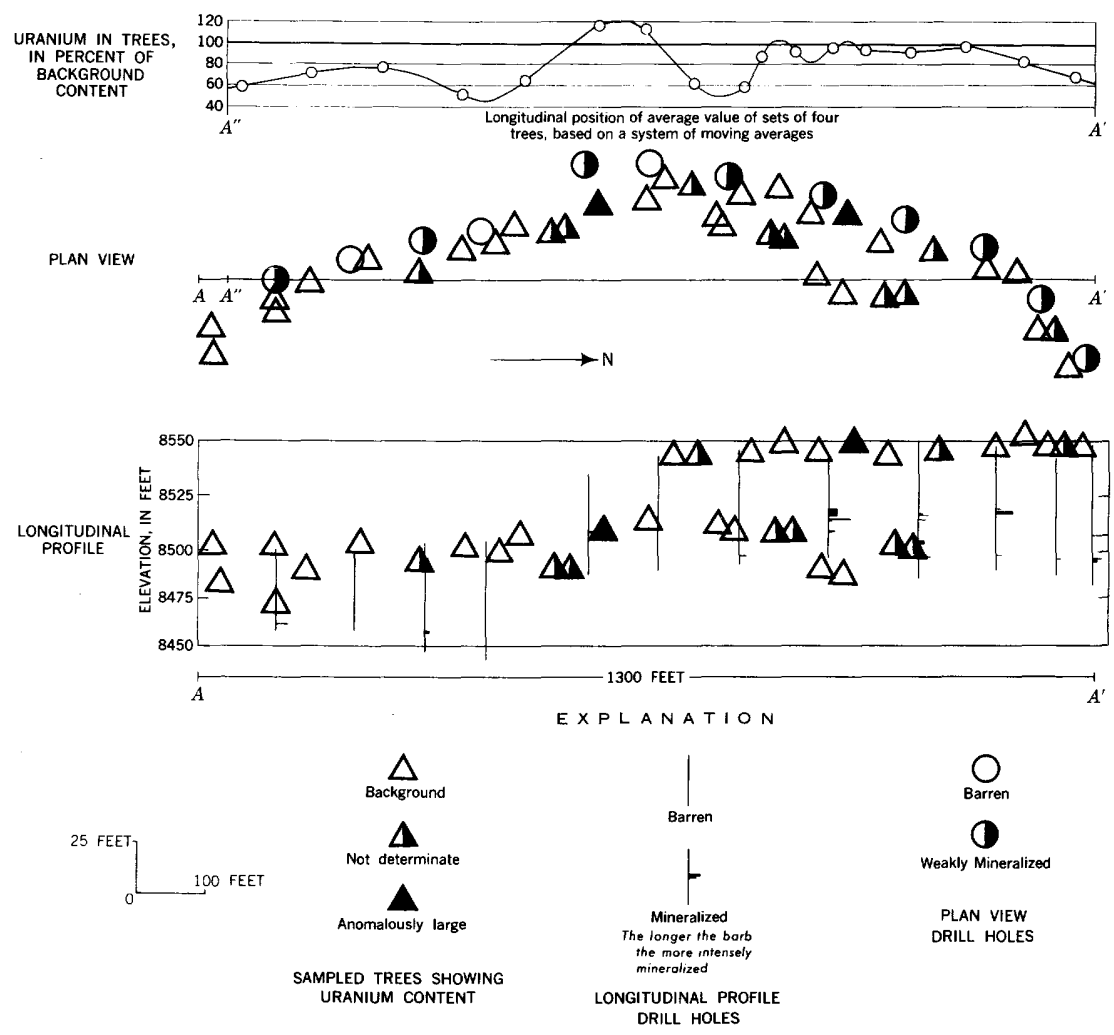

FIGURE 20.-Plant-sample results compared to adjusted drilling data at botanical anomaly 2, subarea 1-S, Elk Ridge, Utah.

remain similar to the correlations obtained from unadjusted drilling data. Empirical observation indicates that the very small but anomalous amounts of uranium, about 10 to $20 \mathrm{ppm} \mathrm{U}$, commonly found in rocks drilled at botanical anomalies will locally suffice for trees to absorb anomalously large quantities. This is in accord with Mehlich and Drake $(1955$, p. 310$)$, who indicate that the ability of a plant to absorb a particular cation may not be dependent solely on a large concentration of that cation in the soil, but may be a function of the source of the ion; that is, organic or inorganic.

\section{SUCCESS EVALUATION BASED ON RADIOACTIVITY TESTING}

In some of the subareas at Elk Ridge, testing of the radioactivity of basal Chinle rocks was done concomitant with plant sampling. Table 6 compares results of the two prospecting methods along about 11 linear miles of test horizon. Based on the large number of cases of coincidence of botanical anomalies with anomalously radioactive 
TABLE 6.- Effect of cover on the frequency of occurrence of botanical anomalies and the detection of anomalous radioactivity, South Elk Ridge, San Juan County, Utah

[" Radioactivity" means anomalous amounts generally at least twice background intensity, but in a few cases amounts barely more than background]

\begin{tabular}{|c|c|c|c|c|c|}
\hline \multirow[b]{2}{*}{ Cover conditions } & \multirow{2}{*}{$\begin{array}{c}\text { Botanical } \\
\text { anomalies } \\
\text { and no } \\
\text { radioactivity }\end{array}$} & \multirow{2}{*}{$\begin{array}{c}\text { Padioactivity } \\
\text { and no } \\
\text { botanical } \\
\text { anomalies }\end{array}$} & \multirow{2}{*}{$\begin{array}{c}\text { Botanical } \\
\text { anomalies } \\
\text { and } \\
\text { radioactivity }\end{array}$} & \multicolumn{2}{|c|}{ Total } \\
\hline & & & & \begin{tabular}{l|} 
Botanical \\
anomalies
\end{tabular} & $\begin{array}{c}\text { Radio- } \\
\text { activity }\end{array}$ \\
\hline $\begin{array}{l}\text { Some exposures-. } \\
\text { Moderately thick colluvium (few } \\
\text { inches to about } 1 \text { to } 2 \mathrm{ft} \text { ) } \\
\text { Thick colluvium (more than about } \\
3 \mathrm{ft} \text { ) }\end{array}$ & 15 & 19 & 14 & $\begin{array}{l}29 \\
21\end{array}$ & 33 \\
\hline Total & 35 & 29 & 19 & 54 & 48 \\
\hline
\end{tabular}

localities (19), probably most of the 35 botanical anomalies not visibly associated with anomalous radioactivity do define mineralized ground but the thickness of cover or incompleteness of radioactivity testing prevented the detection of anomalous radioactivity.

A comparison of frequency of occurrence of botanical anomalies and anomalously radioactive localities with estimates of colluvium thickness in the tested areas indicates that where cover is thickest, frequency of occurrence of both kinds of anomalies is least (table 6). Also, the number of occurrences of both kinds of anomalies falls off greatly with only small increases of thickness. The great fall-off in number of botanical anomalies is attributed chiefly to the shallow effective depth of root pentration, which is a factor not generally present in more arid parts of the Colorado Plateau. Although frequency of occurrence of both kinds of anomalies is least where cover is thickest, botanical anomalies exceed radioactivity anomalies at these places. This might be expected, and indicates that plant-analysis prospecting is still practical where cover thickness is too great for radioactivity prospecting. It should be emphasized that the orders of magnitude of the frequencies listed in table 6 are considered to be reliable even though minor variations of the figures is possible because of the arbitrariness of classifying coincidence of botanical and radioactivity anomalies.

On the qualified assumption that almost all the 54 botanical anomalies in the tested area define mineralized material (table 6) and the fact that about equal numbers of botanical anomalies and radioactive localities were found, it is concluded that plant prospecting in such an area as Elk Ridge is about as successful as radioactivity prospecting. Also, the two prospecting methods tend to complement one another but because radioactivity prospecting is much faster, cheaper, and more reliable, it shoud be used first where cover is not excessive. 


\section{RELIA BILITY OF PLANT-SAMPLE ANALYSIS AND SAMPLING METHODS}

Study of tree-sample data serves to evaluate the reliability of analysis, sampling methods, and botanical anomalies. Cutoffs between background and anomalously large uranium contents in the tree samples lie in the range from about 0.7 to $1.3 \mathrm{ppm}$ in plant ash. These values, consequently, are critical ones. The precision of analysis (discussed under "Uranium content of trees and botanical anomalies") is such that some trees which actually contain uranium in amounts at the low end of this range will not be found, but almost all those with actual uranium contents near the upper end of the range will be detected. It is concluded that the precision with which the laboratory can reproduce analytical results for different portions of the same sample is adequate for plant-analysis prospecting.

Another factor operative in determining the reliability of the analyzed uranium content of tree samples is the representativeness of the sample analyzed. It is well known that the chemical content of some elements, such as copper and uranium, differ considerably for different types of samples, such as berries, leaves, twigs, and branch tips (Warren and Delavault, 1949, p. 541; and Cannon, 1952). Sample material must therefore, be of one type. Also, differences in uranium content may arise because of different ages of sampled parts or because some samples were collected during a wet as opposed to a dry period. The rate of absorption and transfer of nutrients to other plant parts may vary with available moisture. Such differences could cause temporarily altered chemical contents of sampled parts. These differences may be minimized by sampling similar-aged parts during similar weather periods or seasons.

Ten samples, each representing the latest complete one year's growth of branch tips, were collected from 10 trees and analyzed for uranium. Results were compared with uranium analyses made for 10 more samples collected from the same trees. The second set of samples consisted of mixed-age branch tips, duplicating the type samples generally collected during the prospecting at Elk Ridge.

Application of the $F$ and $t$ tests to determine whether or not there is a difference between the sets indicates that no difference is likely to exist (table 7). Thus the rapid method of collecting mixed-age branch tips is probably satisfactory for prospecting. Additional samples would be needed, however, to verify the results of the tests, since the number of samples used was so small. Also, the sampled trees grow in an unmineralized area and contain amounts of uranium near the lower limit of sensitivity of the analytical method. The basic data, then, are not conclusive. This fact may explain the lack of a significant linear correlation between the sets (table 7). 
TABLE 7.- Statistical measures based on plant-sample analyses

\begin{tabular}{|c|c|c|c|c|c|c|c|}
\hline \multirow[t]{2}{*}{ Statistic } & \multirow[t]{2}{*}{$\begin{array}{c}\text { Probability } \\
\text { level } \\
\text { (in percent) }\end{array}$} & \multicolumn{2}{|c|}{$\begin{array}{l}\text { Significant } \\
F \text { and } t \text { values } \\
\text { for sets of } 10 \\
\text { samples each }\end{array}$} & \multicolumn{2}{|c|}{$\begin{array}{c}\text { Significant } \\
F \text { and } t \text { values } \\
\text { for sets of } 44 \\
\text { samples each }\end{array}$} & \multirow[t]{2}{*}{$\begin{array}{l}\text { Branch-tip samples } \\
\text { (mixed-age yersus } \\
\text { latest complete } \\
\text { year's growth-10 } \\
\text { samples each set) }\end{array}$} & \multirow[t]{2}{*}{$\begin{array}{l}\text { Resamples and } \\
\text { reanalysis } \\
(2 \text { sets of } 44 \\
\text { samples each) }\end{array}$} \\
\hline & & $F$ & $t$ & $F$ & $t$ & & \\
\hline & $\begin{array}{l}1 \\
5\end{array}$ & $\begin{array}{l}5.3 \\
3.1\end{array}$ & -..... & $\begin{array}{l}2.0 \\
1.6\end{array}$ & $\mid \begin{array}{l}\ldots \\
\ldots \ldots\end{array}$ & 1.3 & 1.1 \\
\hline$t^{1}-$ & $\begin{array}{l}1 \\
5\end{array}$ & 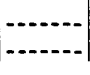 & $\begin{array}{l}2.8 \\
2.1\end{array}$ & ........ & $\begin{array}{l}2.6 \\
1.9\end{array}$ & .39 & .5 \\
\hline \multicolumn{6}{|c|}{ Linear correlation coefficient $(r)$ and $z$-transformation ${ }^{2}--$} & $\begin{array}{rr}r= & -0.16 \\
z= & .17 \\
z= & .38\end{array}$ & $\begin{array}{l}r=+0.84 \\
z=1.22 \\
z=\quad .16\end{array}$ \\
\hline
\end{tabular}

${ }^{1}$ See Youdin, 1951, p. 24-32, 50-51.

${ }^{2}$ See Waugh, 1943, p. 393-402.

To further check the representativeness of the mixed-age branchtip samples, 2 sets of 44 such samples were collected from 44 trees, some of different types, and were analyzed for uranium. A significant positive linear correlation as well as no significant difference between the sets (table 7 ) indicate that the type samples collected are representative and therefore satisfactory for prospecting.

\section{FELATION OF URANIUM IN TREES TO OTHER ELEMENTS IN ROCK AND REGOLITH}

Observations in the Deer Flat-Elk Ridge area have not shown any important unequivocal relations between "soil" elements and botanical anomalies, partly because studies were not extensive, but probably chiefly because soil as such is absent at the sampled horizon. Overburden consists chiefly of colluvium and (or) small or large amounts of residual mineral and organic material. The "soil" elements selected for study are chiefly those essential to plant nutrition, and include calcium $(\mathrm{Ca})$, potassium $(\mathrm{K})$, sulfur $(\mathrm{S})$, phosphorus $(\mathrm{P})$, and copper $(\mathrm{Cu})$. The others, uranium (U) and sodium $(\mathrm{Na})$, are not known to be nutritive elements. All observations were based on analyses for the total concentration of each of these elements (table 8). No comparisons could be made concerning the concentration of each of the elements in the water-soluble portions of the samples chiefly because many of the concentrations were less than the limits of detection.

Correlation diagrams were constructed for most of the regolith elements that had been determined quantitatively in order to relate them to one another and to the uranium content of tree branch-tip samples. Only one unequivocal correlation was found, and that is a positive linear correlation between the regolith constituents sodium and potassium. This is not considered significant with respect to botanical anomalies. 
TABLE 8.- Concentrations of some elements, in percent, in regolith and rock samples, along with uranium content, in parts per million, of branch-tip samples from the nearest trees, Deer Flat-South Elk Ridge, San Juan County, Utah

\begin{tabular}{|c|c|c|c|c|c|c|c|c|c|c|c|c|}
\hline \multicolumn{11}{|c|}{ Regolith and rock samples } & \multicolumn{2}{|c|}{ Nearest tree sample } \\
\hline $\begin{array}{l}\text { Sample } \\
\text { No.1 }\end{array}$ & $\begin{array}{l}\text { Field } \\
\text { No. }\end{array}$ & Location $^{2}$ & $\begin{array}{l}\text { Type and description } \\
\text { of sample }\end{array}$ & $\mathrm{U}$ & $\mathrm{Na}$ & K & $\mathrm{Ca}$ & $\mathrm{P}_{2} \mathrm{O}_{5}$ & $\mathrm{~S}$ & $\mathrm{Cu}$ & $\mathrm{U}$ & Field No. \\
\hline 1 & FJS- 545-21 & $\begin{array}{l}\text { Botanical anomaly } 3, \\
\text { Dead Buck locality, } \\
\text { Deer Flat. }\end{array}$ & Regolith, silty-....... & 0.0017 & 0.05 & 0.35 & 0.17 & 0.089 & 0.02 & 0.0315 & ${ }^{3} 1.7$ & $\begin{array}{l}\text { WRM }-53-101 \\
\text { and } \\
\text { FK-545-1214X }\end{array}$ \\
\hline 2 & FJS -545-28 & 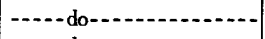 & Regolith-........... & .0002 & .06 & .33 & .33 & .059 & .02 & .0065 & .4 & FK $-545-1224$ \\
\hline 3 & $\begin{array}{c}\text { FJS }-545-26 \\
\text { and } 27 .\end{array}$ & 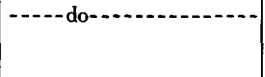 & - & .0004 & .04 & .21 & .28 & .086 & .05 & .0090 & 3.8 & $\begin{array}{l}\text { WRM }-53-93 \\
\text { and } \\
\text { FK }-545-1293\end{array}$ \\
\hline 4 & FJR - 545-23 & - do- & $\begin{array}{l}\text { Regolith and gray } \\
\text { siltstone. }\end{array}$ & .0029 & .05 & .33 & .07 & .19 & .01 & .0240 & 2.1 & FK $-545-1217 \mathrm{X}$ \\
\hline 5 & FJR -545-29 & $\begin{array}{l}\text { Botanical anomaly } 7 \text {, } \\
\text { subarea } 6 \text {, South Elk } \\
\text { Ridge. }\end{array}$ & $\begin{array}{l}\text { Regolith with some } \\
\text { humic material. }\end{array}$ & .0008 & .13 & .58 & 2.93 & .12 & .04 & .0085 & 3.9 & $\begin{array}{l}\text { FK }-445-914 \\
\text { and } \\
\text { FK }-545-914 \mathrm{D}\end{array}$ \\
\hline 6 & FJS $-545-32$ & $\begin{array}{l}\text { Botanical anomaly } 6 \text {, } \\
\text { subarea } 6 \text {, South Elk } \\
\text { Ridge. }\end{array}$ & Regol ith--- & .0002 & .04 & .30 & .79 & .11 & .01 & .0055 & ${ }^{3} 1.9$ & $\begin{array}{c}\text { FK }-445-905 \\
\text { and } \\
\text { FK }-545-905 D\end{array}$ \\
\hline 7 & FJS $-545-3$ & $\begin{array}{l}\text { Between botanical } \\
\text { anomalies } 15 \text { and } 16, \\
\text { subarea } 4 \text {, South Elk } \\
\text { Ridge. }\end{array}$ & (2.-. do- & .0006 & .25 & .96 & .50 & .13 & .03 & .0030 & .4 & FK $-445-601$ \\
\hline 8 & FJS - 545-4 & $\begin{array}{l}\text { Botanical anomaly } 15, \\
\text { subarea } 4 \text {, South Elk } \\
\text { Ridge. }\end{array}$ & $\begin{array}{l}\text { Regolith and gray } \\
\text { sandstone. }\end{array}$ & .0015 & .05 & .23 & .07 & .016 & .02 & .0080 & ${ }^{3} 4.6$ & $\begin{array}{l}\text { FK }-445-592 \\
\text { and } \\
\text { FK -545-592D }\end{array}$ \\
\hline 9 & KS - 545-5 & - - - - do- & -....-do- do & .0002 & .08 & .60 & .21 & .076 & .03 & .0025 & ${ }^{4} 1.1$ & $\begin{array}{l}\text { FK }-445-590 \\
\text { and } 591 ; \\
\text { and } \\
\text { FK - } 545-590 \mathrm{D} \\
\text { and } 591 \mathrm{D} \text {. }\end{array}$ \\
\hline 10 & FJS - 545-6 & $\begin{array}{l}\text { Botanical anomaly } 15, \\
\text { subarea } 4 \text {, South Elk } \\
\text { Ridge. }\end{array}$ & $\begin{array}{l}\text { Regolith and some } \\
\text { sandstone. }\end{array}$ & .0006 & .09 & .35 & .11 & .065 & .03 & .0025 & ${ }^{3} 1.0$ & $\begin{array}{l}\text { FK }-445-589 \\
\text { and } \\
\text { FK - 545-589D }\end{array}$ \\
\hline 11 & FJS - 545-10 & $\begin{array}{l}\text { Botanical anomaly } 5 \text {, } \\
\text { subarea 4, South Elk } \\
\text { Ridge. }\end{array}$ & Regolith-... & .0004 & .13 & .45 & .15 & .054 & .02 & .0055 & .6 & FK $-545-434 \frac{1}{2}$ \\
\hline
\end{tabular}




\begin{tabular}{|c|c|c|c|c|c|c|c|c|c|c|c|c|}
\hline 12 & F JS -545-11 & 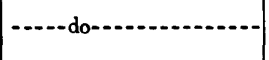 & $\begin{array}{l}\text { Regolith and humic } \\
\text { material. }\end{array}$ & .0006 & .19 & .70 & .29 & .081 & .02 & .0040 & 1.1 & FK $-545-434 \%$ \\
\hline 13 & F JS - 545-12 & $\begin{array}{l}\text { Botanical anomaly } 8 \text {, } \\
\text { subarea } 4 \text {, South Elk } \\
\text { Ridge. }\end{array}$ & - do-chend & .0006 & .06 & .38 & .22 & .11 & .01 & .0090 & .5 & FK $-545-4531 / 2$ \\
\hline 14 & F JR - 545-25 & $\begin{array}{l}\text { Botanical anomaly } 3, \\
\text { Dead Buck locality, } \\
\text { Deer Flat. }\end{array}$ & Black shale-... & .006 & .04 & .13 & .40 & .14 & .59 & .0025 & 3 & $\begin{array}{l}\text { WRM }-53-93 \\
\text { and } \\
\text { FK }-545-1223\end{array}$ \\
\hline 15 & F JR - 545-18 & - & Siltstone, gray- & .0010 & .03 & .28 & .09 & .078 & .05 & .0165 & ${ }^{3} 1.1$ & $\begin{array}{l}\text { WRM }-53-100 \\
\text { and } \\
\text { FK - } 545-1012 X\end{array}$ \\
\hline 16 & F JR -545-16 & $\begin{array}{l}\text { Botanical anomaly 4, } \\
\text { southern Dear Flat } \\
\text { locality. }\end{array}$ & $\begin{array}{l}\text { Siltstone; carbona- } \\
\text { ceous and with } \\
\text { jarosite. }\end{array}$ & .012 & .15 & 1.15 & .02 & .21 & .22 & .0120 & .9 & EEC - 53-280 \\
\hline 17 & F JR $-545-31$ & $\begin{array}{l}\text { Adj acent to Botanical } \\
\text { anomaly } 6, \text { subarea } 6, \\
\text { South Elk Ridge. }\end{array}$ & $\begin{array}{l}\text { Siltstone, carbona- } \\
\text { ceous. }\end{array}$ & .009 & .03 & .38 & .02 & .05 & .02 & .0065 & 2.6 & FK $-445-9081 / 2$ \\
\hline 18 & F JR $-545-13$ & $\begin{array}{l}\text { Between botanical } \\
\text { anomalies } 16 \text { and } 17 \\
\text { subarea } 6 \text {, South Elk } \\
\text { Ridge. }\end{array}$ & $\begin{array}{l}\text { Sandstone, siltstone, } \\
\text { mudstone, carbona- } \\
\text { ceous. }\end{array}$ & .014 & .03 & .60 & .02 & .08 & .09 & .0054 & .3 & FK $-445-1108$ \\
\hline
\end{tabular}

${ }^{1}$ Sample Nos. 1-8, 11-13, 15, and 16 reported in laboratory TDC-6741, dated June Sample Nos. 14, 17, and 18 reported in laboratory TDC-6739, dated June 6, 7.1956. Analysts: R. P. Cox (U), R. F. Dufour (Ca, K, Na), W. D. Goss (Cu), E.C. Mallory, Jr. (S), and J. P. Schuch $\left(\mathrm{P}_{2} \mathrm{O}_{5}\right)$. Sample serial Nos. (in numerical order to correspond with the sample Nos.): $114,118,116$ and 117, 115, 119, 120, $103,104,106,107,108,111$, and 109, to each of which prefix 234 .

Sample Nos. 9 and 10 reported in laboratory TDC -6519 , dated Jan. 12, 1956.

Analysts: R. P. Cox, R. F. Dufour, W. D. Goss, E. C. Mallory, Jr., and J. P.

Schuch. Sample serial Nos. (in numerical order to correspond with the sample

Sample Nos. 14, 17, and 18 reported in laboratory TDC-6739, dated June 6 ,

Mallory, Jr. (S), Wayne Mountjoy $(\mathrm{Ca}, \mathrm{K}, \mathrm{Na})$ and J. P. Schuch $\left(\mathrm{P}_{2} \mathrm{O}_{5}\right)$. Sample

serial Nos. (in numerical order to correspond with the sample Nos.): 234138, 234139 , and 234140 .

${ }^{2}$ Deer Flat localities are designated as reported by Froelich and Kleinhampl (1960, p. 52 and $\mathrm{pl}, 6)$

Nos. ): 234126 and 234127 .

${ }^{3}$ Average of two samples.

Average of four samples. 


\section{GENERAL SUMMARY AND CONCLUSIONS}

The botanical-prospecting program at South Elk Ridge provides information to aid additional prospecting in that area and to aid plantanalysis prospecting in other areas. At South Elk Ridge and probably elsewhere on the Colorado Plateau, background uranium content of trees differs slightly for different genera when the contents are reported in parts per million in plant ash. Utilization of this discovery served to define known botanical anomalies more sharply and also to locate new botanical anomalies.

The different backgrounds for different genera may be inversely related to the average ash content of the respective genera. When uranium content of plants is reported in parts per million in ash, therefore, it seems advisable to use different limits of background uranium content for the tree genera that differ greatly in average ash content. The limits can be established by utilizing a statistical analysis of uranium contents for the different genera and by field observations of the relations of sampled plants to barren and mineralized rock. A crude guide to more precise evaluation of background uranium for evergreen trees in any area may be obtained by determining the average ash content of the type sample used for each kind of tree. Background uranium content should be slightly greater for a tree type with a small average ash content than for a tree with a large average ash content. This guide presumes the universality of the inverse relation of background uranium content to ash content for all kinds of evergreen trees, and possibly scrub oak and aspen on the Colorado Plateau.

Choice of a sample horizon appears to be very limited in the cool moist upper parts of South Elk Ridge. Here, and probably in other places of similar climate on the Colorado Plateau, the effective depth of root penetration is locally very shallow or erratic, and plants cannot be relied upon to tap the ore zone where they grow more than 20 feet vertically above it. Minor uranium deposits overlying the ore zone can prevent distinguishing the effects that deposits at the ore zone have on sampled plants.

Botanical prospecting chiefly on South Elk Ridge located 110 botanical anomalies along about 30 linear miles of tested horizon at the base of the Chinle formation. Most of the anomalies are in subareas 1,4 , and 6 . In general, these three subareas also contain the anomalies rated most favorable for containing minable quantities of uranium. Many of the anomalies on the east side of Woodenshoe Canyon (subarea 5) also appear favorable for containing minable quantities of uranium; some may coincide with favorable channel-fill units that are continuous into the area from just south of the tested part of 
Cherry Canyon (subarea 4). In general, additional testing programs should give priority to the botanical anomalies in subareas 1-N, 4, 5,6 , and 7 because the known ore deposits and the rocks with most favorable lithology and structure for containing uranium ore deposits lie generally within these subareas.

In this paper priority in the selection of botanical anomalies for physical exploration has been discussed by subarea and specific botanical anomaly. Those anomalies having the best favorableness rating for containing minable quantities of uranium and that lie within the most favorable subareas deserve greatest priority in any exploration plans. Based on the frequency of occurrence and size of known uranium deposits and ore production in the basal Chinle rocks of the Deer Flat-South Elk Ridge area (Finch, 1955), none or only a few of the botanical anomalies found should be expected to indicate deposits containing 1,000 or more tons of ore.

Plant-analysis prospecting at Deer Flat and South Elk Ridge was able to define mineralized localities with a success about equal to that of radioactivity testing and, according to the most realistic of two methods of comparison, with success twice as great and almost as great, respectively, as that by drilling at random and by drilling at geologically selected channel-fillings. Colluvium as little as 1 to 3 feet thick restricts the effectiveness of prospecting by the radioactivity method more than by the plant-analysis method. Where both of these methods are applicable, they tend to complement one another in usefulness.

It is impossible to predict reliably the grade and precise extent of uranium deposits by plant-analysis prospecting because of complicating factors of environment and because trees appear to be able to absorb uranium in anomalously large but inconstant amounts that are not usually in proportion to the amount in the rooting medium. Material containing as little as 10 to $20 \mathrm{ppm} \mathrm{U}$ may locally suffice for trees to absorb anomalously large quantities.

Uranium analyses of replicate plant samples (mixed-age branch tips) yield results that are satisfactorily reproducible for the plantprospecting method. The tests supplement empirical observations at Deer Flat, Elk Ridge, and other places on the Colorado Plateau concerning the close association of botanical anomalies and uraniferous localities.

The comparisons made in the study relating plant, regolith, and rock constituents showed no relations considered to be significant to plant-analysis prospecting. It is emphasized, however, that the observations were based on inadequate data. It is hoped that future studies will show the nature of the absorption, transport, and emplacement of uranium in plants. 


\section{TABLE 9.-Botannical anomalies, their lengths, and the trees that mark the extremities of the anomalies}

[Sample numbers listed are arranged in the order of botanical anomaly numbers. The first and last sample numbers listed for each anomaly alwavs mark the extremity of the anomaly. Samples between those marking the extremities of the anomalies are numbered consecutively, except where indicated by more than one consecutive sequence within each anomaly. Sample no.: Letters (AJF, FK), collector's initials; numbers $(-53)$ year sample collected, $(-674)$ specimen no.; the first digit of the 3-digit number following FK indicates the year (1954 in F K-440-51)]

\begin{tabular}{|c|c|c|c|c|c|}
\hline $\begin{array}{l}\text { Botanical } \\
\text { anomaly } \\
\text { (Pl. 9) }\end{array}$ & $\begin{array}{l}\text { Anom- } \\
\text { aly } \\
\text { length } \\
\text { (feet) }\end{array}$ & Tree sample number & $\begin{array}{l}\text { Botanical } \\
\text { anomaly } \\
\text { (Pl. 9) }\end{array}$ & $\begin{array}{l}\text { Anom- } \\
\text { aly } \\
\text { length } \\
\text { (feet) }\end{array}$ & Tree sample number \\
\hline
\end{tabular}

Subarea 1-S (south of The Notch)

\begin{tabular}{|c|c|c|c|c|c|}
\hline $\begin{array}{l}\text { 3. } \\
4 \\
5 \\
6 \\
6 \\
7 \\
8\end{array}$ & $\begin{array}{l} \\
300 \\
450 \\
150 \\
150 \\
200 \\
400\end{array}$ & $\begin{array}{l}\text { FK-4-40-51 to }-43 \\
\text { FK-440-26 to }-22 ;-1 \text { to } \\
-8 ;-17 \text { to }-18 ;-88 \text { to }-91 \\
\text { (lower sample hori- } \\
\text { zon), }-97 \text { to }-104 \text { (upper } \\
\text { sample horizon) } \\
\text { FK }-440-114 \text { to }-119 \\
\text { AJF-53-634 to }-643 \\
\text { AJF-53-662 to }-664 \\
\text { AJF-53-674 to }-676 \\
\text { AJF-53-609 to }-616 \\
\text { AJF-53-624 to }-628\end{array}$ & $\begin{array}{l}9 \\
10 \\
11 \\
12 \\
13 \\
14 \\
15 \\
16 \\
17 \\
18 \\
19 \\
20\end{array}$ & $\begin{array}{r}50 \\
500 \\
425 \\
500 \\
50 \\
250 \\
250 \\
2,000 \\
450 \\
50 \\
150 \\
200\end{array}$ & $\begin{array}{l}\text { AJF-53-699 } \\
\text { FK-440-131 to }-143 \\
\text { FK-440-174 to }-179 \\
\text { FK-440-189 to }-196 \\
\text { FK }-440-202-1 / 2 \\
\text { FK }-445-208 \text { to }-211 \\
\text { FK-445-233 to }-238 \\
\text { FK }-445-245 \text { to }-274 \\
\text { FK-445-275 to }-283 \\
\text { FK-445-312 } \\
\text { FK }-445-319 \text { to }-323 \\
\text { FK }-445-346 \text { to }-348\end{array}$ \\
\hline
\end{tabular}

Subarea 1-N (north of The Notch)

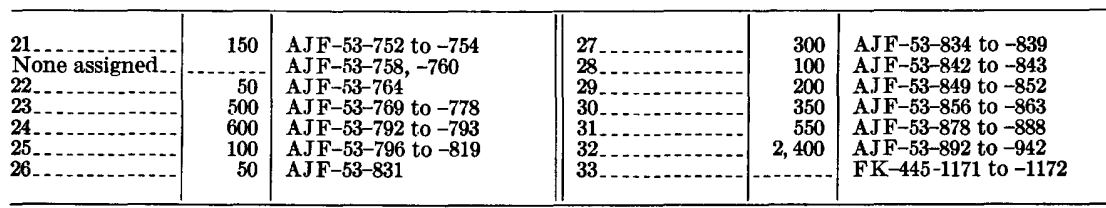

Subarea 2

\begin{tabular}{|c|c|c|c|c|c|}
\hline $\begin{array}{l}1 \\
\mathbf{2} \\
\mathbf{3} \\
\mathbf{4}\end{array}$ & $\begin{array}{r}50 \\
175 \\
225 \\
200\end{array}$ & $\begin{array}{l}\text { FK-445-707 } \\
\text { FK-445-712 to }-714 \\
\text { FK-445-745 to }-746 \\
\text { FK }-445-773 \text { to }-775\end{array}$ & $\begin{array}{l}\text { 5. } \\
6 \\
\mathbf{7} \\
\mathbf{8}\end{array}$ & $\begin{array}{r}50 \\
115 \\
150 \\
115\end{array}$ & $\begin{array}{l}\text { FK-445-780 } \\
\text { FK }-445-791 \text { to }-792 \\
\text { FK-445-803 to }-805 \\
\text { FK }-445-829 \text { to }-830\end{array}$ \\
\hline
\end{tabular}

Subarea 3

[No botanical anomalies]

\begin{tabular}{|c|c|c|c|c|c|}
\hline \multicolumn{6}{|c|}{ Subarea 4} \\
\hline $\begin{array}{l}1 \\
6 \\
6 \\
6 \\
6 \\
8\end{array}$ & $\begin{array}{r}50 \\
360 \\
50 \\
150 \\
145 \\
75 \\
50 \\
110 \\
50\end{array}$ & $\begin{array}{l}\text { FK }-445-368 \\
\text { FK }-445-373 \text { to }-376 \\
\text { FK }-445-381 \\
\text { FK }-445-384 \text { to }-386 \\
\text { FK-445-432 to }-434 \\
\text { FK }-445-440 \\
\text { FK }-445-446 \\
\text { FK }-445-453 \text { to }-454 \\
\text { FK }-445-467 \text { to }-469\end{array}$ & $\begin{array}{l}10 \\
11 \\
12 \\
13 \\
14 \ldots \\
15 \\
16 \ldots \ldots\end{array}$ & $\begin{array}{r}50 \\
50 \\
50 \\
50 \\
100 \\
\\
\\
250 \\
50\end{array}$ & $\begin{array}{l}\text { FK-445-502 } \\
\text { FK-445-507 } \\
\text { FK-445-532 } \\
\text { FK-445-553 } \\
\text { FK-445-561 (upper tra- } \\
\text { vers ), -571 to }-572 \\
\text { (lower traverse } \\
\text { FK-445-586 to }-593 \\
\text { FK }-445-617\end{array}$ \\
\hline
\end{tabular}

Subarea 5

\begin{tabular}{|c|c|c|c|c|c|}
\hline $\begin{array}{l}1 \\
2 \\
2 \\
3 \\
4 \\
5 \\
6 \\
7\end{array}$ & $\begin{array}{r}50 \\
50 \\
50 \\
100 \\
250 \\
50 \\
50\end{array}$ & $\begin{array}{l}\text { AJF-53-325 } \\
\text { AJF-53-335 } \\
\text { AJF-53-343 } \\
\text { AJF-53-357 to }-358 \\
\text { AJF-53-368 to }-372 \\
\text { AJF-53-255 } \\
\text { AJF-53-424 }\end{array}$ & $\begin{array}{l}8 \\
9 \\
10 \\
11 \\
13\end{array}$ & $\begin{array}{r}50 \\
50 \\
50 \\
50 \\
100 \\
50\end{array}$ & $\begin{array}{l}\text { AJF-53-441 } \\
\text { AJF-53-468 } \\
\text { AJF-53-479 } \\
\text { AJF-53-552 } \\
\text { AJF-53-559 to }-560 \\
\text { AJF-53-596 }\end{array}$ \\
\hline
\end{tabular}


TABLE 9.-Botanical anomalies, their lengths, and the trees that mark the extremities of the anomalies-Continued

\begin{tabular}{|c|c|c|c|c|c|}
\hline $\begin{array}{l}\text { Botanical } \\
\text { anomaly } \\
\text { (Pl. 9) }\end{array}$ & $\begin{array}{c}\text { Anom- } \\
\text { aly } \\
\text { length } \\
\text { (feet) }\end{array}$ & Tree sample number & $\begin{array}{l}\text { Botanical } \\
\text { anomaly } \\
(\text { Pl. 9) }\end{array}$ & $\begin{array}{c}\text { Anom- } \\
\text { aly } \\
\text { length } \\
\text { (feet) }\end{array}$ & Tree sample number \\
\hline \multicolumn{6}{|c|}{ Subarea 6} \\
\hline $\begin{array}{l}1 \\
2 \\
3\end{array}$ & $\begin{array}{r}1600 \\
100 \\
100 \\
50 \\
200 \\
225 \\
50 \\
100 \\
2475 \\
200 \\
150 \\
50 \\
50 \\
50\end{array}$ & 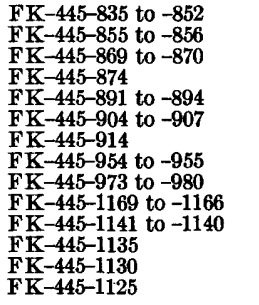 & $\begin{array}{l}15 \\
16 \\
17 \\
18 \\
19 \\
20 \\
21 \\
22\end{array}$ & $\begin{array}{r}50 \\
100 \\
2300 \\
425 \\
125 \\
125 \\
50 \\
350 \\
\\
50 \\
50\end{array}$ & $\begin{array}{l}\text { FK-445-1116 } \\
\text { FK-445-1110 to }-1109 \\
\text { FK-445-1104 to }-1101 \\
\text { FK-445-1082 to }-1075 \\
\text { FK-445-1060 to }-1059 \\
\text { FK-445-1053 to }-1052 \\
\text { FK-445-1045 } \\
\text { FK-445-1032 to }-1023 \\
\text { (some trees on lower } \\
\text { horizon at base of a } \\
\text { sandstone ledge) } \\
\text { FK-445-1010, -1009 } \\
\text { (superposed) } \\
\text { FK-445-993 }\end{array}$ \\
\hline
\end{tabular}

Subarea 7

\begin{tabular}{|c|c|c|c|c|c|}
\hline $\begin{array}{l}1 \\
2 \\
3 \\
4 \\
5\end{array}$ & $\begin{array}{r}250 \\
250 \\
50 \\
50 \\
50 \\
50\end{array}$ & $\begin{array}{l}\text { AJF-53-14 to }-18 \\
\text { AJF-53-26 to }-30 \\
\text { AJF-53-39 } \\
\text { AJF-53-48 } \\
\text { AJF-53-53 } \\
\text { AJF-53-91 }\end{array}$ & $\begin{array}{l}7 \\
8 \\
9 \\
10 \\
11\end{array}$ & $\begin{array}{r}50 \\
50 \\
50 \\
-150 \\
50 \\
300\end{array}$ & $\begin{array}{l}\text { AJF-53-95 } \\
\text { AJF-53-105 } \\
\text { AJF-53-123 } \\
\text { AJF-53-183 to }-185 \\
\text { AJF-53-192 } \\
\text { AJF-53-197 to }-202\end{array}$ \\
\hline
\end{tabular}

Subarea 8

\begin{tabular}{l|l|l|l|l|}
\hline 175 & FK-445-629 to -631 & & & \\
\hline
\end{tabular}

Subarea 9

\begin{tabular}{r|r|r||r|r}
\hline 150 & FK-445-657 to -655 & 3 & 250 & F K $-445-686$ to -690 \\
\hline
\end{tabular}

1 Adjusted because of irregularity of topography.

2 Probably too large because of inclusion of many trees containing background uranium. 
TABLE 10.-Reliability of botanical anomalies and reasons for the ratings, South Elk Ridge, San Juan County, Utah

[See section "Uranium content of trees and botanical anomalies" for criteria used to evaluate reliability . Symbols: $X$, applicable description;?, uncertain]

\begin{tabular}{|c|c|c|c|c|c|c|c|c|c|c|c|c|c|c|c|c|c|}
\hline \multirow{3}{*}{$\begin{array}{l}\text { Botanical } \\
\text { anomaly } \\
\text { (Pl. 9) }\end{array}$} & \multicolumn{4}{|c|}{$\begin{array}{l}\text { Reliability of } \\
\text { anomaly }\end{array}$} & \multicolumn{3}{|c|}{$\begin{array}{l}\text { Number } \\
\text { of trees }\end{array}$} & \multicolumn{2}{|c|}{$\begin{array}{l}\text { Tree dis- } \\
\text { tribution }\end{array}$} & \multicolumn{2}{|c|}{$\begin{array}{l}\text { Con- } \\
\text { trast }\end{array}$} & \multicolumn{2}{|c|}{$\begin{array}{l}\text { Uranium con- } \\
\text { tent of trees }\end{array}$} & \multirow{2}{*}{\multicolumn{2}{|c|}{$\begin{array}{c}\text { Con- } \\
\text { firmed by } \\
\text { reanalyses } \\
\text { and re- } \\
\text { sampling }\end{array}$}} & \multirow{2}{*}{\multicolumn{2}{|c|}{$\begin{array}{c}\text { Anoma- } \\
\text { lous } \\
\text { radio- } \\
\text { activity } \\
\text { at } \\
\text { locality }\end{array}$}} \\
\hline & 胥 & & & & & & & & & & & 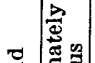 & $g$ & & & & \\
\hline & 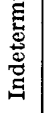 & 苍 & 䓵 & $\begin{array}{l}\text { ¿ } \\
0\end{array}$ & 1 & 2 & $>2$ & 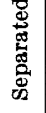 & 苞 & 昰 & 莺 & 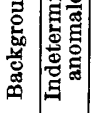 & 赵范 & No & Yes & No & Yes \\
\hline
\end{tabular}

\section{A. Subarea 1-S}

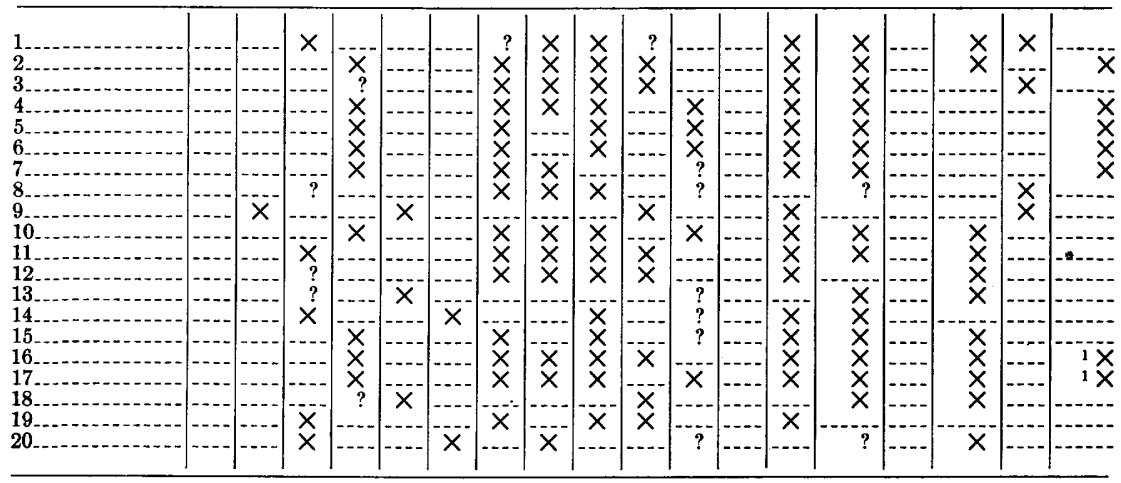

B. Subarea 1-N

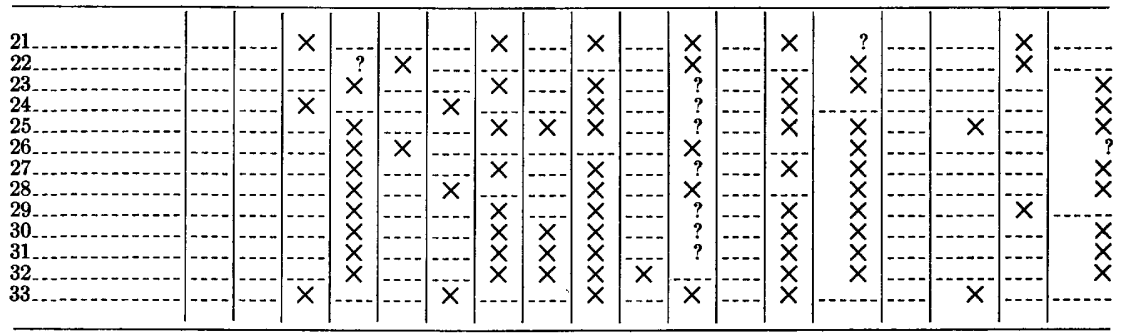

C. Subarea 2

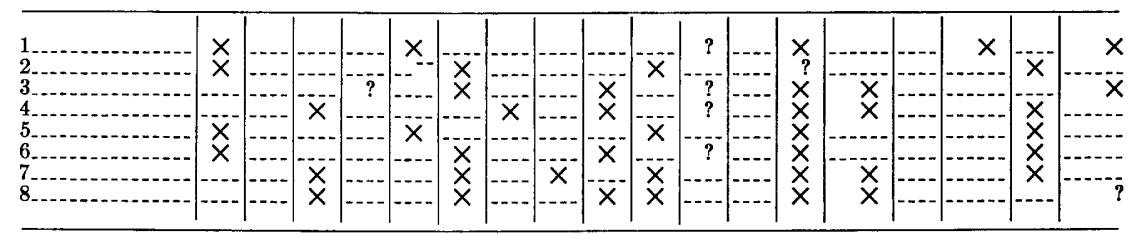

See footnotes at end of table. 
TABLE 10.-Reliability of botanical anomalies and reasons for the ratings, South Elk Ridge, San Juan County, Utah-Continued

\begin{tabular}{|c|c|c|c|c|c|c|c|c|c|c|c|c|c|c|c|c|c|c|}
\hline \multirow{3}{*}{$\begin{array}{l}\text { Botanical } \\
\text { anomaly } \\
(\text { Pl. 9) }\end{array}$} & \multicolumn{4}{|c|}{$\begin{array}{l}\text { Reliability of } \\
\text { anomaly }\end{array}$} & \multicolumn{3}{|c|}{$\begin{array}{l}\text { Number } \\
\text { of trees }\end{array}$} & \multicolumn{2}{|c|}{$\begin{array}{l}\text { Tree dis } \\
\text { tribution }\end{array}$} & \multicolumn{2}{|c|}{$\begin{array}{l}\text { Con- } \\
\text { trast }\end{array}$} & \multicolumn{3}{|c|}{$\begin{array}{l}\text { Uranium con- } \\
\text { tent of trees }\end{array}$} & \multirow{2}{*}{\multicolumn{2}{|c|}{$\begin{array}{l}\text { Con- } \\
\text { firmed by } \\
\text { reanalyse } \\
\text { and re- } \\
\text { sampling }\end{array}$}} & \multirow{2}{*}{\multicolumn{2}{|c|}{$\begin{array}{c}\text { Anoma- } \\
\text { lous } \\
\text { radio- } \\
\text { activity } \\
\text { at } \\
\text { locality }\end{array}$}} \\
\hline & $\stackrel{8}{8}$ & & & & & & & & & & & $=$ & & $g$ & & & & \\
\hline & 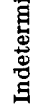 & 蒿 & 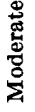 & $\begin{array}{l}8 \\
8 \\
0\end{array}$ & 1 & 2 & $>2$ & 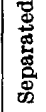 & 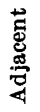 & $\begin{array}{l}\overline{\bar{\varpi}} \\
\text { 营 }\end{array}$ & 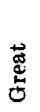 & 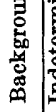 & हี: & 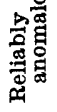 & No & Yes & No & Yes \\
\hline
\end{tabular}

\section{Subarea 4}

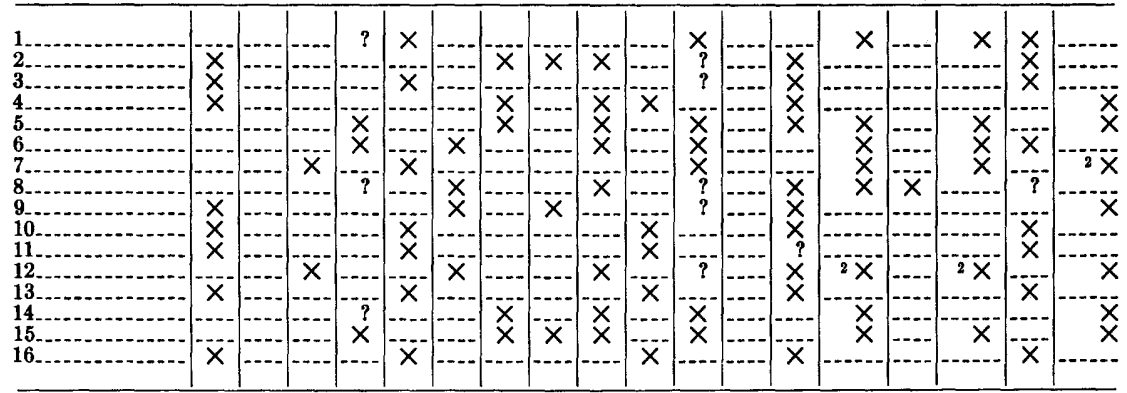

\section{E. Subarea 5}

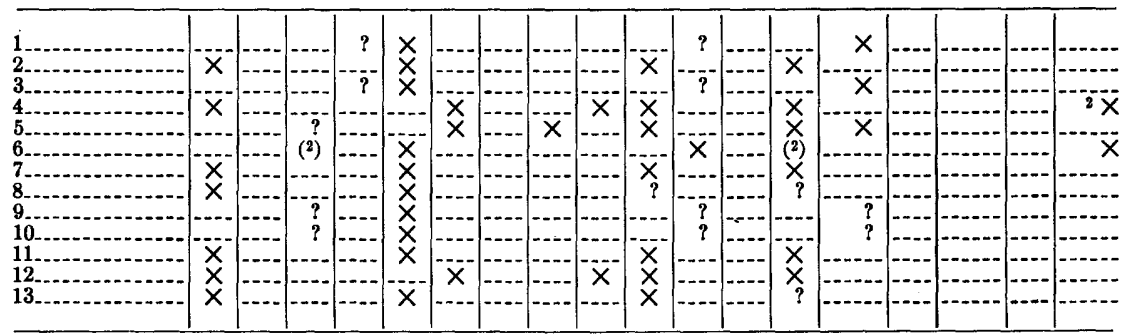

\section{F. Subarea 6}

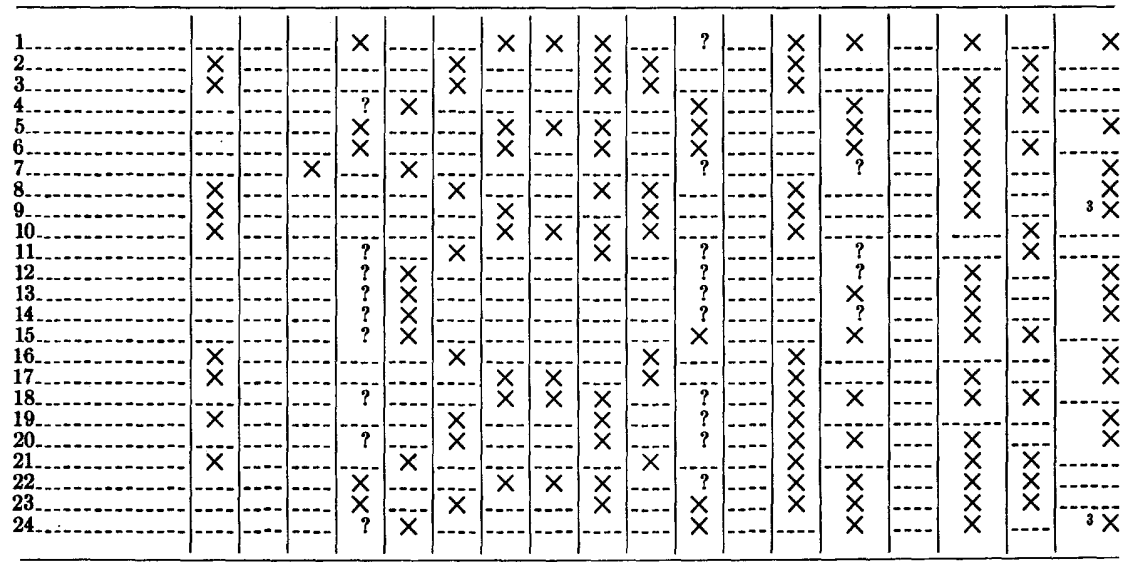

See footnotes at end of table. 
TABLE 10.-Reliability of botanical anomalies and reasons for the ratings, South Elk Ridge, San Juan County, Utah-Continued

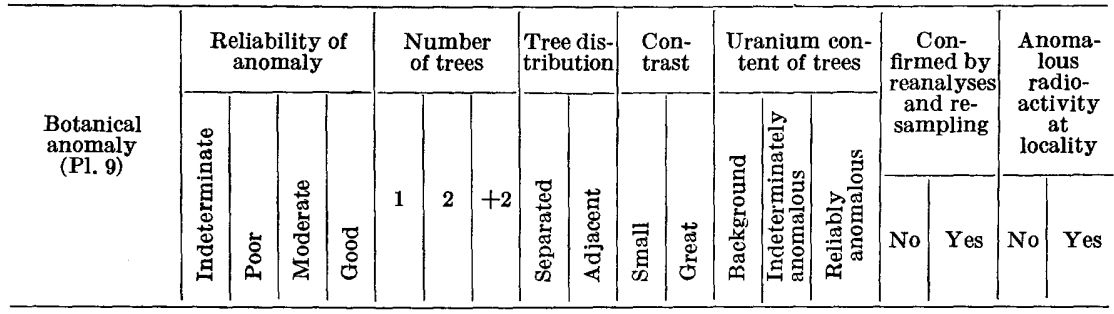

G. Subarea 7

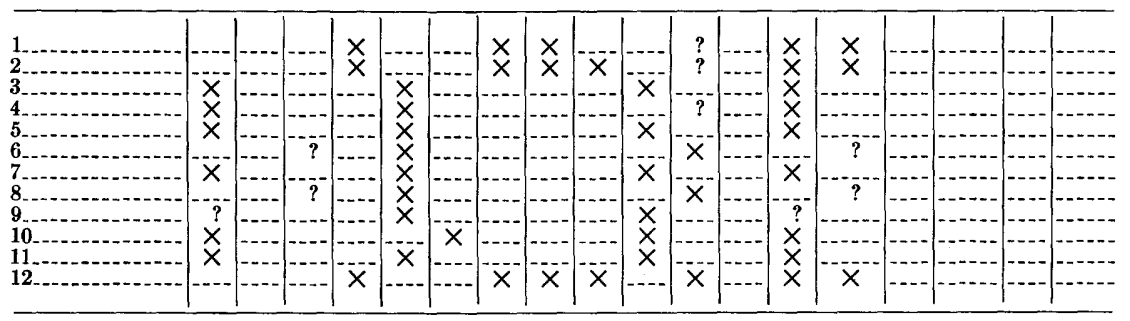

\section{H. Subarea 9}

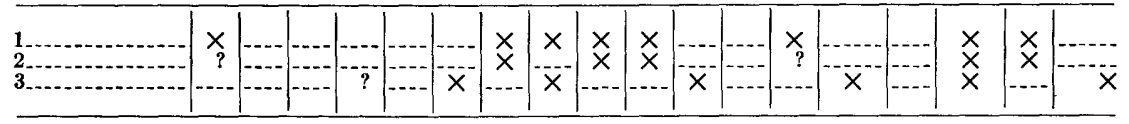

1 Found by intensive testing after discovery of the botanical anomaly.

2 See "Results of physical exploration at anomalies" for this subarea.

3 Radioactivity found only after stripping of overburden. 
TABLE 11.-Botanical anomaly ratings as to favorableness for uranium ore deposits, and reasons for the ratings, South Elk Ridge, San Juan County, Utah

[Symbols: $X$, applicable description; ?, uncertain; $I$, inferred-next best inference is in next less favorable numerical category]

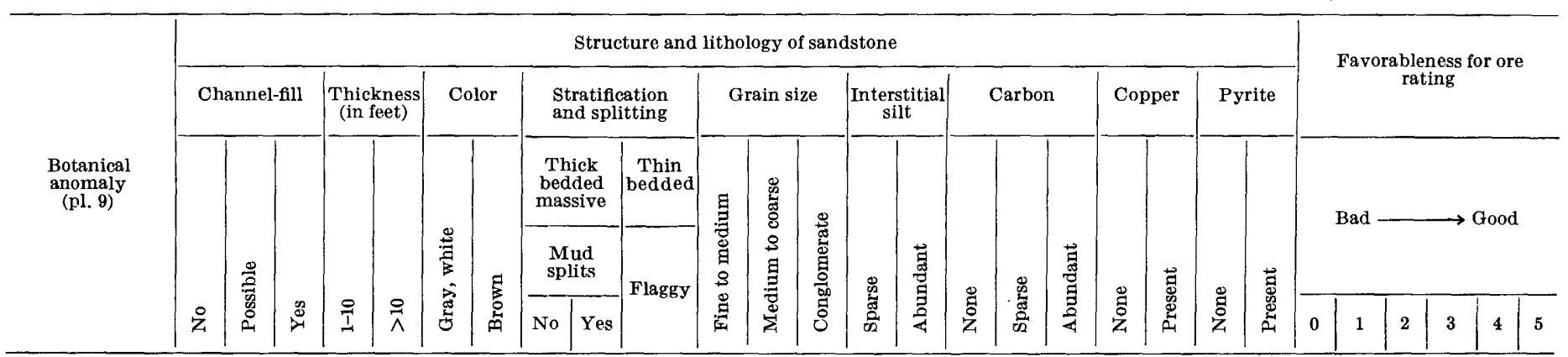

A. Subarea 1-s

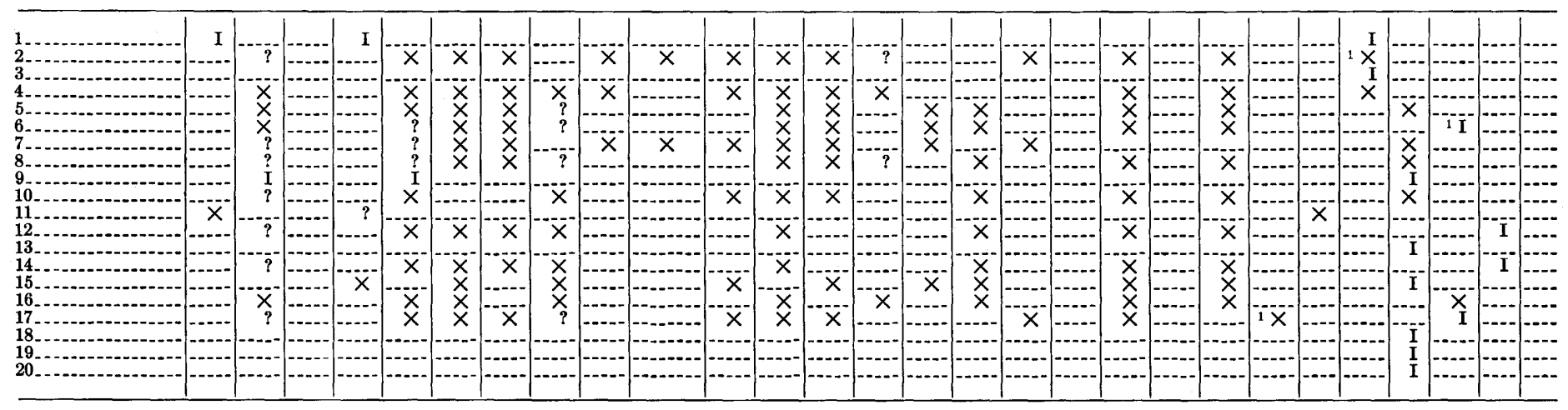


TABLE 11.-Botanical anomaly ratings as to favorableness for uranium ore deposits, and reasons for the ratings, South Elk Ridge, San Juan County, Utah-Continued

[Symbols: $X$, applicable description; ?, uncertain; I, inferred-next best inference is in next less favorable numerical category]

\begin{tabular}{|c|c|c|c|c|c|c|c|c|c|c|c|c|c|c|c|c|c|c|c|c|c|c|c|c|c|c|c|c|}
\hline \multirow{5}{*}{$\begin{array}{c}\text { Botanical } \\
\text { anomaly } \\
\text { (pl. 9) }\end{array}$} & \multicolumn{22}{|c|}{ Structure and lithology of sandstone } & \multirow{2}{*}{\multicolumn{6}{|c|}{$\begin{array}{l}\text { Favorableness for ore } \\
\text { rating }\end{array}$}} \\
\hline & \multicolumn{3}{|c|}{ Channel-fill } & \multicolumn{2}{|c|}{$\begin{array}{c}\text { Thickness } \\
\text { (in feet) }\end{array}$} & \multicolumn{2}{|c|}{ Color } & \multicolumn{3}{|c|}{$\begin{array}{l}\text { Stratification } \\
\text { and splitting }\end{array}$} & \multicolumn{3}{|c|}{ Grain size } & \multicolumn{2}{|c|}{$\left|\begin{array}{c}\text { Interstitial } \\
\text { silt }\end{array}\right|$} & \multicolumn{3}{|c|}{ Carbon } & \multicolumn{2}{|c|}{ Copper } & \multicolumn{2}{|c|}{ Pyrite } & & & & & & \\
\hline & \multirow[b]{3}{*}{ z } & \multirow{3}{*}{$\begin{array}{l}\stackrel{0}{0} \\
\text { 总 } \\
\text { 员 }\end{array}$} & \multirow[b]{3}{*}{$\sum_{\nu}^{\infty}$} & \multirow[b]{3}{*}{$\stackrel{ }{I}$} & \multirow[b]{3}{*}{$\stackrel{\ominus}{\wedge}$} & \multirow{3}{*}{ 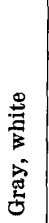 } & \multirow{3}{*}{ 草 } & \multirow{2}{*}{\multicolumn{2}{|c|}{$\begin{array}{c}\begin{array}{c}\text { Thick } \\
\text { bedded } \\
\text { massive }\end{array} \\
\begin{array}{c}\text { Mud } \\
\text { splits }\end{array} \\
\end{array}$}} & \multirow{3}{*}{\begin{tabular}{|l} 
Thin \\
bedded
\end{tabular}} & \multirow{3}{*}{ 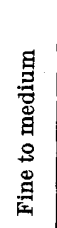 } & \multirow{3}{*}{ 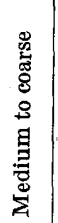 } & \multirow{3}{*}{ 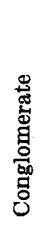 } & \multirow{3}{*}{ 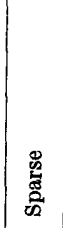 } & \multirow{3}{*}{ 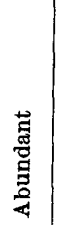 } & \multirow{3}{*}{ 妾 } & \multirow{3}{*}{ 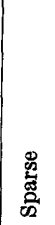 } & \multirow{3}{*}{ 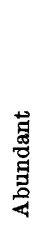 } & \multirow{3}{*}{$\begin{array}{l}\stackrel{8}{0} \\
\text { z }\end{array}$} & \multirow{3}{*}{$\begin{array}{l}\text { 若 } \\
\text { 怘 } \\
\text { م. }\end{array}$} & \multirow{3}{*}{ 号 } & & & Bad & & $\rightarrow$ & 1000 & \\
\hline & & & & & & & & & & & & & & & & & & & & & & $\overleftrightarrow{\sharp}$ & & & & & & \\
\hline & & & & & & & & No & Yes & & & & & & & & & & & & & 总 & 0 & 1 & 2 & 3 & 4 & 5 \\
\hline
\end{tabular}

\section{B. Subarea $1-\mathbf{N}$}

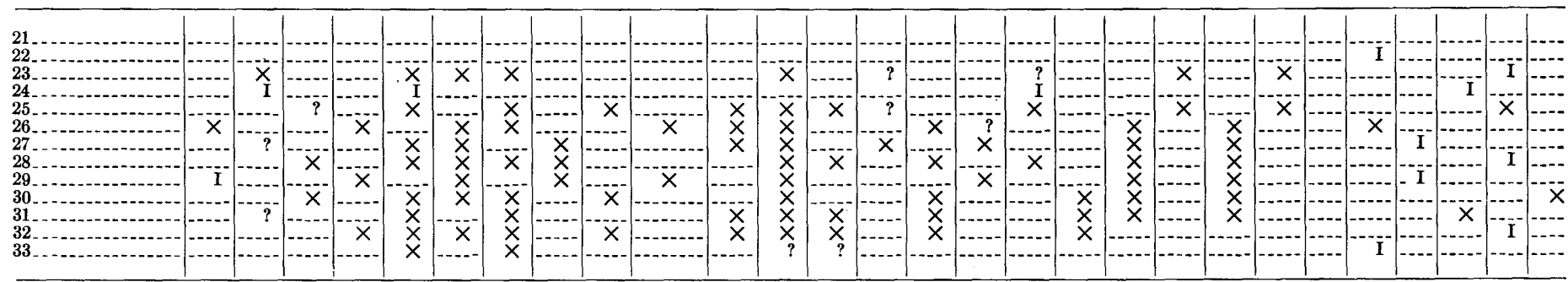




\section{c. Subarea 2}

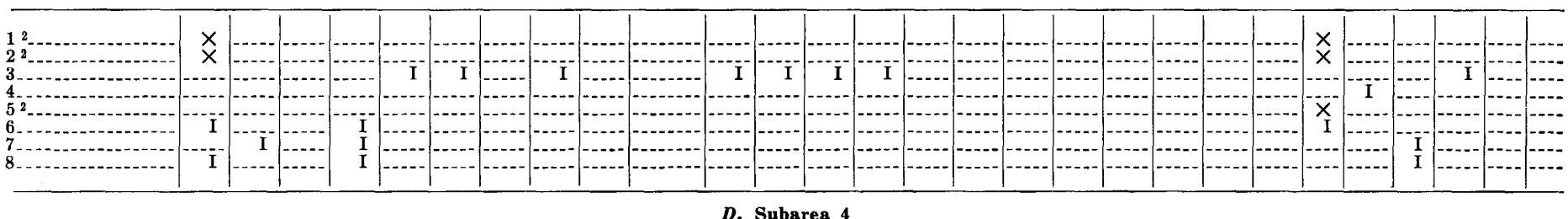

D. Subarea 4

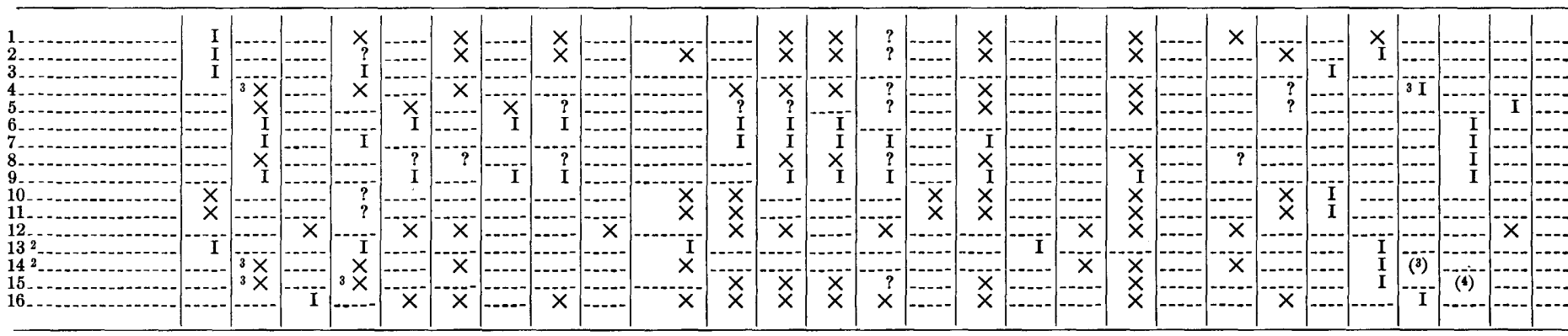

E. Subarea 5

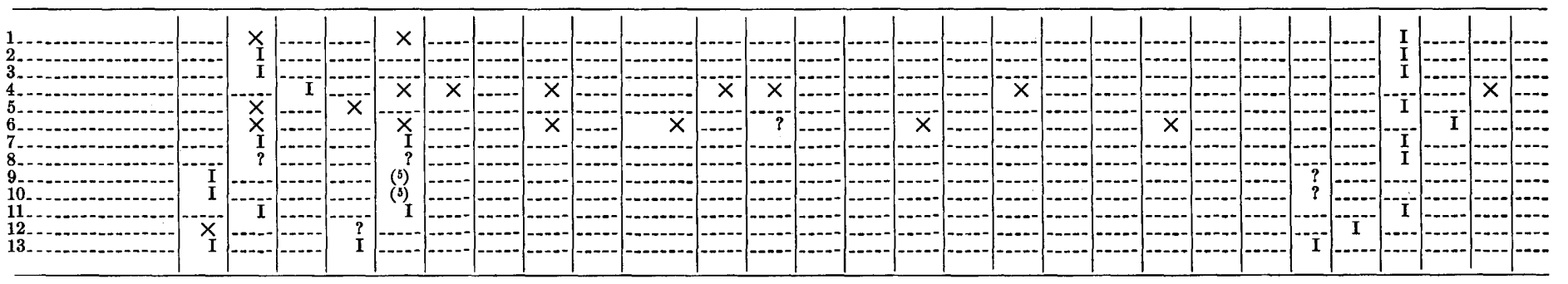


Table 11.-Botanical anomaly ratings as to favorableness for uranium ore deposits, and reasons for the ratings, South Elk Ridge, San Juan County, Utah-Continued

[Symbols: $X$, applicable description; ?, uncertain; $I$, inferred-next best inference is in next less favorable numerical category]

\begin{tabular}{|c|c|c|c|c|c|c|c|c|c|c|c|c|c|c|c|c|c|c|c|c|c|c|c|c|c|c|c|c|}
\hline \multirow{5}{*}{$\begin{array}{c}\text { Botanical anomaly } \\
\text { (pl. 9) }\end{array}$} & \multicolumn{22}{|c|}{ Structure and lithology of sandstone } & \multirow{2}{*}{\multicolumn{6}{|c|}{$\begin{array}{l}\text { Favorableness for ore } \\
\text { rating }\end{array}$}} \\
\hline & \multicolumn{3}{|c|}{ Channel-fill } & \multicolumn{2}{|c|}{$\begin{array}{c}\text { Thickness } \\
\text { (in feet) }\end{array}$} & \multicolumn{2}{|c|}{ Color } & \multicolumn{3}{|c|}{$\begin{array}{l}\text { Stratification } \\
\text { and splitting }\end{array}$} & \multicolumn{3}{|c|}{ Grain size } & \multicolumn{2}{|c|}{$\begin{array}{c}\text { Interstitial } \\
\text { silt }\end{array}$} & \multicolumn{3}{|c|}{ Carbon } & \multicolumn{2}{|c|}{ Copper } & \multicolumn{2}{|c|}{ Pyrite } & & & & & & \\
\hline & \multirow[b]{3}{*}{$\stackrel{\circ}{\mathrm{z}}$} & \multirow{3}{*}{$\begin{array}{l}\stackrel{0}{0} \\
0 \\
08 \\
0\end{array}$} & \multirow[b]{3}{*}{$\underbrace{\infty}_{0}$} & \multirow[b]{3}{*}{$\stackrel{ }{1}$} & \multirow[b]{3}{*}{$\stackrel{\wedge}{\wedge}$} & \multirow{3}{*}{ 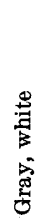 } & \multirow{3}{*}{ 吾 } & \multirow{2}{*}{\multicolumn{2}{|c|}{$\begin{array}{c}\begin{array}{c}\text { Thick } \\
\text { bedded } \\
\text { massive }\end{array} \\
\begin{array}{c}\text { Mud } \\
\text { splits }\end{array}\end{array}$}} & \multirow{3}{*}{$\begin{array}{c}\begin{array}{c}\text { Thin } \\
\text { bedded }\end{array} \\
\text { Flaggy }\end{array}$} & \multirow{3}{*}{ 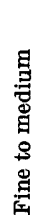 } & \multirow{3}{*}{ 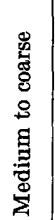 } & \multirow{3}{*}{$\begin{array}{l}\frac{8}{\pi} \\
\text { घूँ } \\
0 \\
00 \\
0 \\
0\end{array}$} & \multirow{3}{*}{$\begin{array}{l}\text { 怘 } \\
\text { 品 } \\
\text { 品 }\end{array}$} & \multirow{3}{*}{ 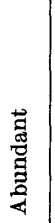 } & \multirow{3}{*}{$\begin{array}{l}\text { ̊ } \\
\text { 乙 }\end{array}$} & \multirow{3}{*}{ 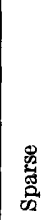 } & \multirow{3}{*}{ 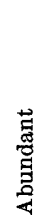 } & \multirow{3}{*}{$\begin{array}{l}\text { 巳 } \\
\text { 乙 }\end{array}$} & \multirow{3}{*}{ 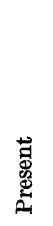 } & \multirow{3}{*}{$\begin{array}{l}\text { 范 } \\
\text { z }\end{array}$} & & & & d- & $\rightarrow 0$ & & \\
\hline & & & & & & & & & & & & & & & & & & & & & & $\vec{g}$ & & & & & & \\
\hline & & & & & & & & No & Yes & & & & & & & & & & & & & 总 & 0 & 1 & 2 & 3 & 4 & 5 \\
\hline
\end{tabular}

\section{F. Subsrea 6}

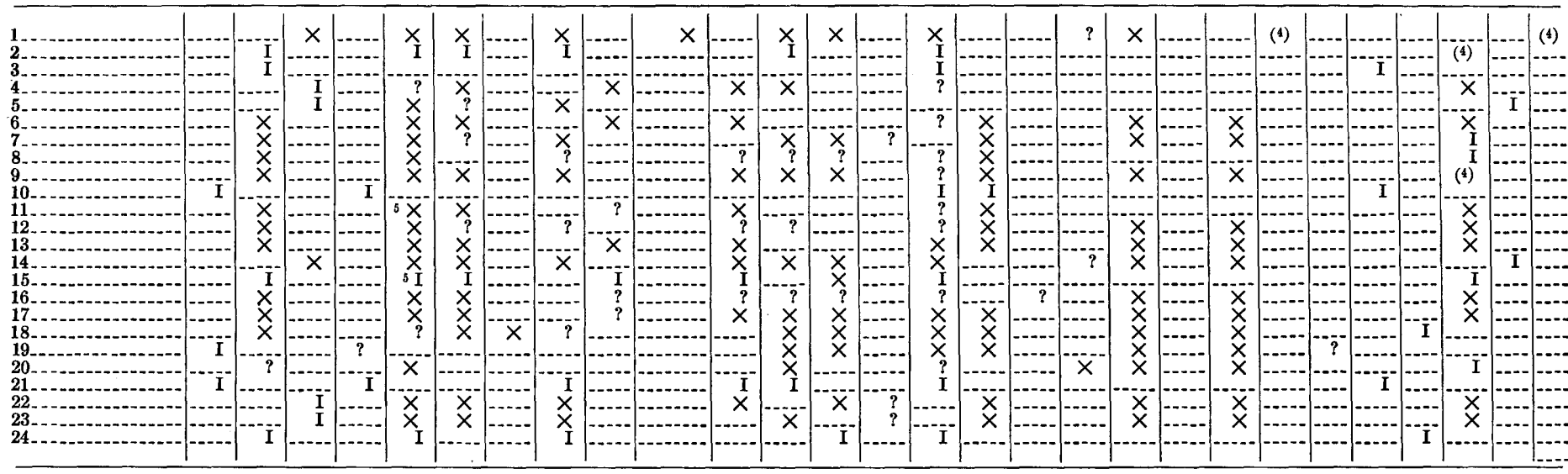

1 Based partly on drilling results.

4 See "Results of physical exploration at botanical anomalies" for this subarea. 


\section{LITERATURE CITED}

Baker, A. A., 1935, Geologic structure of southeastern Utah : Am. Assoc. Petroleum Geologists Bull., v. 19, no. 10, p. 1472-1507.

Cannon, H. L., 1952, The effect of uranium-vanadium deposits on the vegetation of the Colorado Plateau: Am. Jour. Sci., v. 250, no. 10, p. 735-770.

1954, Botanical methods of prospecting for uranium: Mining Eng., v. 6, p. 217-220.

Gottle, H. J., 1932, Vegetation on north and south slopes of mountains in south-

western Texas: Ecology, v. 13, p. 121-134.

Daubenmire, R. F., 1943, Vegetational zonation in the Rocky Mountains: Bot. Rev., v. 9, p. 325-393.

Fersman, A. Ye, 1939, Geokhimicheskiye i minerologicheskiye metody poiskov poleznykh iskopayemykh (Geochemical and mineralogical methods of prospecting for mineral deposits) : Akad. Nauk SSSR, Moscow (English translation of Chap. IV, Special methods of prospecting, by Lydia Hartsock and A. P. Pierce: U.S. Geol. Survey Circ. 127, 37 p., 1952).

Finch, W. I., 1955, Preliminary geologic map showing the distribution of uranium deposits and principal ore-bearing formations of the Colorado Plateau region: U.S. Geol. Survey Mineral Inv. Field Studies Map, MF-16.

Finnell, T. L., Franks, P. C., and Hubbard, H. A., 1962, Geology, ore deposits, and exploratory drilling in the Deer Flat area, White Canyon district, San Juan County, Utah: U.S. Geol. Survey Bull. 1132. (In press.)

Froelich, A. J., and Kleinhampl, F. J., 1960, Botanical prospecting for uranium in the Deer Flat area, White Canyon district, San Juan County, Utah : U.S. Geol. Survey Bull. 1085-B, p. 51-84.

Gail, F. W., 1921, Factors controlling the distribution of Douglas fir in semiarid regions of the northwest: Ecology, v. 2, p. 281-291.

Garrels, R. M., and Christ, C. L., 1956, Field studies on the origin of primary uranium ores in the western United States, in Geologic investigations of radioactive deposits, semiannual progress report, June 1 to November 30 , 1956: U.S. Geol. Survey TEI-640, p. 300-301, issued by U.S. Atomic Energy Comm. Tech. Inf. Service, Oak Ridge, Tenn.

Gregory, H. E., 1938, The San Juan country, a geographic and geologic reconnaissance of southeastern Utah : U.S. Geol. Survey Prof. Paper 188, 123 p.

Gruner, J. W., and Gardiner, Lynn, 1952, Mineral associations in the uranium deposits of the Colorado Plateau and adjacent regions with special emphasis on those in the Shinarump formation, in pt. 3, Annual Rept., July 1, 1951 to June 30, 1952: RMO-566, issued by U.S. Atomic Energy Comm. Tech. Inf. Service, Oak Ridge, Tenn.

Harrington, H. D., 1954, Manual of the plants of Colorado: Denver, Colo., Sage Books.

Hawkes, H. E., 1954, Geochemical prospecting investigations in the Nyeba leadzinc district, Nigeria : U.S. Geol. Survey Bull. 1000-B, p. 51-103 [1955].

Katz, J. J., and Rabinowitch, Eugene, 1951, The element, its binary, and related compounds, pt. I, of The chemistry of uranium: New York, McGraw-Hill Book Co., Inc., 609 p.

Kelsey, H. P., and Dayton, W. A., 1942, Standardized plant names : Harrisburg, Pa., J. Horace McFarland Co., 675 p.

Lewis, R. Q., Sr., and Campbell, R. H., 1958a, Preliminary geologic map of the Elk Ridge 2 SE quadrangle, San Juan County, Utah: U.S. Geol. Survey Mineral Inv. Field Studies Map MF-193 [1959]. 
Lewis, R. Q. Sr., and Campbell, R. H., 1958b, Preliminary geologic map of the Elk Ridge 3 NW quadrangle, San Juan County, Utah: U.S. Geol. Survey Mineral Inv. Field Studies Map MF-195 [1959].

1959a, Preliminary geologic map of the Elk Ridge 3 NE quadrangle, San Juan County, Utah: U.S. Geol. Survey Mineral Inv. Field Studies Map MF-194.

1959b, Preliminary geologic map of the Elk Ridge 4 NW quadrangle, San Juan County, Utah: U.S. Geol. Survey Mineral Inv. Field Studies Map MF-199.

Little, E. L., Jr., 1953 Check list of native and naturalized trees of the United States (including Alaska): U.S. Dept. Agriculture, Agriculture Handbook 41, $472 \mathrm{p}$.

McKee, E. D., and Weir, G. W., 1953, Terminology for stratification and crossstratification in sedimentary rocks: Geol. Soc. America Bull., v. 64, p. 381-389.

Mehlich, Adolph, and Drake, Mack, 1955, Soil chemistry and plant nutrition, in Bear, F. E., ed., Chemistry of the soil : New York, Reinhold Publishing Corp., p. 286-327.

Rice, C. M., 1949, Dictionary of geological terms: Ann Arbor, Mich., Edwards Brothers, Inc., $464 \mathrm{p}$.

Rydberg, P. A., 1917, Flora of the Rocky Mountains and adjacent plains: New York, published by author, $1,110 \mathrm{p}$.

Shoemaker, E. M., Miesch, A. T., Newman, W. L., and Riley, L. B., 1955, Elemental composition of Colorado Plateau sandstone-type uranium deposits : TEI-446 (Unclassified) ; also revised in Garrels, R. M., and Larsen, E. S., 3d, 1959, Geochemistry and mineralogy of the Colorado Plateau uranium ores: U.S. Geol. Survey Prof. Paper 320, 236 p.

Stewart, J. H., 1957, Proposed nomenclature of part of Upper Triassic strata in southeastern Utah: Am. Assoc. Petroleum Geologists Bull., v. 41, p. 441-465.

1959, Stratigraphic relations of Hoskinnini member (Triassic?) of Moenkopi formation on Colorado Plateau: Am. Assoc. Petroleum Geologists Bull., v. 43, p. 1852-1868.

Tansley, A. G., 1935, The use and abuse of vegetational concepts and terms: Ecology, v. 16, p. 284-307.

Trites, A. F., and Chew, R. T., III, 1955, Geology of the Happy Jack mine, White Canyon area, San Juan County, Utah: U.S. Geol. Survey Bull. 1009-H, p. $235-248$.

Warren, H. V., and Delavault, R. E., 1949, Further studies in biogeochemistry : Geol. Soc. America Bull., v. 60, no. 3, p. 531-559.

Waugh, A. E., 1943, Elements of statistical method: New York, McGraw-Hill Book Co., Inc., 532 p.

Weaver, J. E., and Clements, F. E., 1938, Plant ecology : New York and London, McGraw-Hill Book Co., Inc., 601 p.

Weeks, A. D., 1956, Mineralogy and oxidation of the Colorado Plateau uranium ores, in United Nations, Geology of uranium and thorium: Internat. Conf. on Peaceful Uses Atomic Energy, 1st, Geneva 1955, Proc., v. 6, p. 525-529; also in Page, L. R., and others, compilers, Contributions to the geology of uranium and thorium by the United States Geological Survey and Atomic Energy Commission for the United Nations International Conference on Peaceful Uses of Atomic Energy, Geneva, Switzerland, 1955: U.S. Geol. Survey Prof. Paper 300, p. 187-193. 
Weeks, A. D., and Thompson, M. E., 1954, Identification and occurrence of uranium and vanadium minerals from the Colorado Plateaus: U.S. Geol. Survey Bull. 1009-B, p. 13-62.

Witkind, I. J., 1956, Uranium deposits at base of the Shinarump conglomerate, Monument Valley, Arizona: U.S. Geol. Survey Bull. 1030-C, p. 99-130.

Woodbury, A. M., 1947, Distribution of pigmy conifers in Utah and northeastern Arizona : Ecology, v. 28, p. 113-126.

Youdin, W. J., 1951, Statistical methods for chemists: New York, John Wiley and Sons, Inc., $126 \mathrm{p}$.

\section{STANDARD PLAN'T NAMES USED IN THIS REPORT}

In the following list the plants are arranged alphabetically within their families, which are listed in the commonly accepted order of primitive families, to complex composites. The Latin and common names are from Kelsey and Dayton (1942), the authority and classification are according to Harrington (1954), and abbreviation according to Rydberg (1917).

Family Pinaceae:

Abies concolor Lindl.

white fir.

Juniperus communis $\mathrm{L}$. common juniper. monosperma (Engelm.) Sarg. oneseed juniper. scopulorum Sarg. Rocky Mountain juniper. utahensis (Engelm.) Lemmon Utah juniper.

Pinus oembroides var. edulis Zucc. ponderosa var. scopulorum (Engelm.) Lemmon Colorado pinyon pine.

Pseudotsuga taxifolia Britt*

Rocky Mountain ponderosa pine. common Douglas fir.

Family Gramineae:

Oryzopsis hymenoides (R. and S.) Rick. Indian ricegrass.

Family Liliaceae :

Allium sp. onion.

Calochortus nuttalli Torr. segolily mariposa.

Family Rosaceae:

Amelanchier alnifolia Nutt. saskatoon serviceberry.

Cercocarpus montanus Raf. true mountainmahogany.

Covania stansburiana Torr. Stansbury cliffrose.

Fallugia paradoxa (D. Don) Endl. apacheplume.

Purshia tridentata (Pursh) D.C. antelope bitterbrush.

Family Leguminosae:

Astragalus sp. vetch.

Lathyrus sp. peavine.

Family Salicaceae:

Populus tremuloides Michx. quaking aspen. Family Corylaceae: Betula fontinalis Sarg. water birch. Family Fagaceae: Quercus gambeli Nutt. Gambel oak (scrub oak).

\footnotetext{
${ }^{1}$ Based on Little (1953, p. 2, 305-308), this name should probably be Pseudotsuga menziesii var. glauca (Beissn.) Franco, according to work by Franco, as a variety distinct from $P$. menziesii var. menziesii, which is the Pacific Coast tree.
} 
188 Botanical PROSPECTING, URANIUM, COLORAdo PLATEAU

Family Polygonaceae:

Eriogonum sp. eriogonum.

Family Chenopodiaceae : Atriplex confertifolia (Torr. and Frem.) _.-_- shadscale saltbush.

Family Berberidaceae: Mahonia fremonti Fedde Fremont mahonia (holly grape).

Family Aceraceae: Acer glabrum Torr.

Rocky Mountain maple.

Family Ericaceae:

Arctostaphylos potula Greene greenleaf manzanita.

Family Scrophulariaceae: Castilleja angustifolia Pursh narrowleaf paintedcup (paintbrush).

Family Caprifoliaceae:

Symphoricarpos oreophilus A. Gray mountain snowberry. Family Compositae:

Artemisia tridentata Nutt. big sagebrush. Solidago petradoria Blake. rock goldenrod. 